Prepared for the U.S. Department of Energy under Contract DE-AC05-76RL01830

\title{
Reduced-Order Model for the
} Geochemical Impacts of Carbon Dioxide, Brine, and Trace Metal Leakage into an Unconfined, Oxidizing Carbonate Aquifer, Version 2.1

\author{
DH Bacon
}

March 2013

Pacific Northwest

NATIONAL LABORATORY

Proudly Operated by Battelle Since 1965 


\title{
DISCLAIMER
}

This report was prepared as an account of work sponsored by an agency of the United States Government. Neither the United States Government nor any agency thereof, nor Battelle Memorial Institute, nor any of their employees, makes any warranty, express or implied, or assumes any legal liability or responsibility for the accuracy, completeness, or usefulness of any information, apparatus, product, or process disclosed, or represents that its use would not infringe privately owned rights. Reference herein to any specific commercial product, process, or service by trade name, trademark, manufacturer, or otherwise does not necessarily constitute or imply its endorsement, recommendation, or favoring by the United States Government or any agency thereof, or Battelle Memorial Institute. The views and opinions of authors expressed herein do not necessarily state or reflect those of the United States Government or any agency thereof.

\author{
PACIFIC NORTHWEST NATIONAL LABORATORY \\ operated by \\ BATTELLE \\ for the \\ UNITED STATES DEPARTMENT OF ENERGY \\ under Contract DE-AC05-76RL01830
}

Printed in the United States of America
Available to DOE and DOE contractors from the Office of Scientific and Technical Information,
P.O. Box 62, Oak Ridge, TN 37831-0062; ph: (865) 576-8401
fax: $(865) 576-5728$
email: reports(a)adonis.osti.gov

Available to the public from the National Technical Information Service 5301 Shawnee Rd., Alexandria, VA 22312

ph: (800) 553-NTIS (6847)

email: orders@ntis.gov $<$ http://www.ntis.gov/about/form.aspx $>$

Online ordering: http://www.ntis.gov

This document was printed on recycled paper. 


\section{Reduced-Order Model for the Geochemical Impacts of Carbon Dioxide, Brine, and Trace Metal Leakage into an Unconfined, Oxidizing Carbonate Aquifer, Version 2.1}

DH Bacon

March 2013

Prepared for

the U.S. Department of Energy

under Contract DE-AC05-76RL01830

Pacific Northwest National Laboratory

Richland, Washington 99352 



\begin{abstract}
The National Risk Assessment Partnership (NRAP) consists of five U.S. Department of Energy national laboratories collaborating to develop a framework for predicting the risks associated with carbon sequestration. The approach taken by NRAP is to divide the system into components, including injection target reservoirs, wellbores, natural pathways including faults and fractures, groundwater, and the atmosphere. Next, develop a detailed, physics- and chemistry-based model of each component. Using the results of the detailed models, develop efficient, simplified models, termed reduced-order models (ROMs), for each component. Finally, integrate the component ROMs into a system model that calculates risk profiles for the site. This report details Pacific Northwest National Laboratory's development of the groundwater geochemistry ROM for the Edwards Aquifer in south-central Texas. The groundwater geochemistry ROM for the Edwards Aquifer uses the Wellbore Leakage ROM developed at Los Alamos National Laboratory as input. The detailed model, using the STOMP (Subsurface Transport Over Multiple Phases) simulator, covers a $5 \times 8-\mathrm{km}$ area of the Edwards Aquifer near San Antonio, Texas. The model includes heterogeneous hydraulic properties as well as equilibrium, kinetic, and sorption reactions between groundwater, leaked carbon dioxide $\left(\mathrm{CO}_{2}\right)$ gas, brine, and the aquifer carbonate and clay minerals. Latin Hypercube sampling was used to generate 1024 samples of input parameters. For each of these input samples, the STOMP simulator was used to predict the flux of $\mathrm{CO}_{2}$ to the atmosphere along with the volume, length, and width of the aquifer in which $\mathrm{pH}$ was below a threshold value and total dissolved solids (TDS), arsenic, cadmium, and lead exceeded a threshold concentration. Two different sets of threshold values were used: either the drinking water standard maximum contaminant level (MCL) or no-impact threshold values based on maximum observed concentrations. To decouple the Wellbore Leakage ROM from the groundwater geochemistry ROM, the response surface was transformed to replace Wellbore Leakage ROM input parameters with instantaneous and cumulative $\mathrm{CO}_{2}$ and brine leakage rates. The most sensitive parameters proved to be the $\mathrm{CO}_{2}$ and brine leakage rates from the well; equilibrium coefficients for calcite and dolomite, as well as the number of illite and kaolinite sorption sites, proved to be of secondary importance. The groundwater geochemistry ROM was developed using nonlinear regression to fit the response surface with a quadratic polynomial. The goodness of fit was excellent for the $\mathrm{CO}_{2}$ flux to the atmosphere, and very good for predicting the volumes of groundwater exceeding the $\mathrm{pH}$, TDS, arsenic, cadmium, and lead threshold values.
\end{abstract}





\section{Summary}

The National Risk Assessment Partnership (NRAP) is a U.S. Department of Energy-funded program to develop and demonstrate a methodology and toolset for predicting long-term risk profiles needed for quantifying potential liabilities at a carbon dioxide $\left(\mathrm{CO}_{2}\right)$ storage project. Five national laboratories are participating in the partnership: the National Energy Technology Laboratory (NETL), Lawrence Berkeley National Laboratory (LBNL), Los Alamos National Laboratory (LANL), Lawrence Livermore National Laboratory, and Pacific Northwest National Laboratory (PNNL). Potential risks include the return of $\mathrm{CO}_{2}$ to the atmosphere, impacts on groundwater chemistry, and induced seismic events. The return of $\mathrm{CO}_{2}$ to the atmosphere could result in the loss of $\mathrm{CO}_{2}$ credits. Impacts on groundwater relate to exceeding regulatory limits for groundwater contaminants.

The approach taken by NRAP is to divide the system into components, including injection target reservoirs, wellbores, and natural pathways including faults and fractures, groundwater, and the atmosphere. Next, develop a detailed physics- and chemistry-based model of each component. Using the results of the detailed models, develop efficient, simplified models, termed reduced-order models (ROMs), for each component. Finally, integrate the component ROMs into a system model that calculates risk profiles for the site.

The groundwater component models are based on two sites: the confined, reducing, sandstone High Plains Aquifer, which extends from South Dakota to Texas, and the unconfined, oxidizing carbonate Edwards Aquifer in south-central Texas. Two ROMs have been developed for each aquifer, one with varied hydraulic parameters, and another with varied geochemical parameters, resulting in four separate groundwater ROMs. This report focuses on PNNL's development of the geochemical ROM for the Edwards Aquifer.

The approach used to develop the groundwater geochemistry ROM for the Edwards Aquifer was to develop a complex model of groundwater flow and reactive transport in the shallow, urban unconfined portion of the aquifer near San Antonio, Texas. The areal model domain covers a $5 \times 8-\mathrm{km}$ area and is $150 \mathrm{~m}$ thick, with upscaled heterogeneous porosity and permeability. This model, using the STOMP simulator, used a Wellbore Leakage ROM provided by LANL to calculate $\mathrm{CO}_{2}$ and brine leakage rates into the aquifer. The STOMP (Subsurface Transport Over Multiple Phases) model included equilibrium, kinetic mineral, and adsorption reactions related to the carbonate and clay minerals in the aquifer reacting with major ions and trace metals in groundwater, as well as $\mathrm{CO}_{2}$ and brine containing sodium $(\mathrm{Na})$, chloride $(\mathrm{Cl})$, arsenic $(\mathrm{As})$, cadmium $(\mathrm{Cd})$, and lead $(\mathrm{Pb})$ leaking from the wellbore.

Base-case model results use a $\mathrm{CO}_{2}$ leakage rate of a little over $0.005 \mathrm{~kg} / \mathrm{s}$ and a brine leakage rate of $0.0005 \mathrm{~kg} / \mathrm{s}$ as input. Two different sets of threshold values were used: either the drinking water standard maximum contaminant level (MCL) or no-impact threshold values based on maximum observed concentrations. The drinking water MCLs are defined by the U.S. Environmental Protection Agency as $\mathrm{pH}<6.5$, total dissolved solids (TDS) $>500 \mathrm{mg} / \mathrm{L}, \mathrm{As}>10 \mu \mathrm{g} / \mathrm{L}, \mathrm{Cd}>5 \mu \mathrm{g} / \mathrm{L}$ and $\mathrm{Pb}>15 \mu \mathrm{g} / \mathrm{L}$. The no-impact threshold values were determined to be $\mathrm{pH}<6.6$, TDS $>420 \mathrm{mg} / \mathrm{L}$, As $>0.55 \mu \mathrm{g} / \mathrm{L}$, $\mathrm{Cd}>0.04 \mu \mathrm{g} / \mathrm{L}$ and $\mathrm{Pb}>0.15 \mu \mathrm{g} / \mathrm{L}$. Using the MCL limits, the TDS plume reached a volume of $2.0 \mathrm{E}+07 \mathrm{~m}^{3}$ after 200 years, the $\mathrm{pH}$ plume reached a volume of $9.0 \mathrm{E}+06 \mathrm{~m}^{3}$, and the $\mathrm{Pb}$ plume reached $3.5 \mathrm{E}+06 \mathrm{~m}^{3}$ in volume. Arsenic and $\mathrm{Cd}$ did not exceed the threshold limits. Using the no-impact threshold limits, the $\mathrm{pH}$ and TDS plumes were slightly larger, whereas the trace metal plumes were 
notably larger: the TDS plume reached a volume of $2.5 \mathrm{E}+07 \mathrm{~m}^{3}$ after 200 years, the pH plume reached a volume of $1.1 \mathrm{E}+06 \mathrm{~m}^{3}$, the As plume reached $3.3 \mathrm{e}+06 \mathrm{~m}^{3}$ in volume, the Cd plume nearly $1.0 \mathrm{E}+06 \mathrm{~m}^{3}$ in volume, and the $\mathrm{Pb}$ plume $1.4 \mathrm{E}+07 \mathrm{~m}^{3}$ in volume.

Using Latin Hypercube sampling, a number of geochemical parameters and wellbore ROM parameters were varied to generate 1024 random samples. The STOMP simulator was run 1024 times to calculate $\mathrm{pH}, \mathrm{TDS}$, and $\mathrm{As}, \mathrm{Cd}$, and $\mathrm{Pb}$ concentrations in the groundwater, as well as the $\mathrm{CO}_{2}$ flux to the atmosphere across the water table. Based on these results, the size of the affected volume of the aquifer based on regulatory limits was calculated. The size of the $\mathrm{pH}$, TDS, As, Cd, and Pb plumes, along with the $\mathrm{CO}_{2}$ flux to the atmosphere, compose the response of the aquifer to variations in model input parameters. While 89 to $91 \%$ of the samples resulted in $\mathrm{pH}$ or TDS plumes exceeding either the MCL or no-impact threshold limits, when the MCL limits are used only $17 \%$ of the samples result in Cd plumes and $37 \%$ of the samples result in As plumes exceeding the threshold limits, while $63 \%$ of the samples result in $\mathrm{Pb}$ plumes that exceed the threshold limits. Using the no-impact threshold limits, $62 \%$ of the samples exceeded the As limits, $61 \%$ exceeded the $\mathrm{Cd}$ limits, and $91 \%$ exceeded the $\mathrm{Pb}$ limits. $\mathrm{CO}_{2}$ flux to the atmosphere at 200 years was recorded for $69 \%$ of the sample runs.

To facilitate the development of the groundwater geochemistry ROM, the original response surface, with output values at selected times, was transformed so that time effectively became an additional input parameter, and the output variables became functions of time. The response surface was transformed again to decouple the Wellbore Leakage ROM from the groundwater geochemistry ROM for the Edwards Aquifer. For a given input sample at a particular time, the Wellbore Leakage ROM input parameters were used to run the Wellbore Leakage ROM and to calculate the $\mathrm{CO}_{2}$ leak rate and the brine leak rate, as well as the cumulative mass of $\mathrm{CO}_{2}$ and brine leaked up to that time. These four values at each input time then became four new input parameters, replacing the three input parameters for the Wellbore Leakage ROM.

Important input parameters were identified using multivariate adaptive regression splines (MARS) parameter ranking. For the $\mathrm{CO}_{2}$ flux to the atmosphere, the $\mathrm{CO}_{2}$ wellbore leakage rate was the only significant parameter. The most significant parameter for the TDS plume size was the cumulative mass of $\mathrm{CO}_{2}$ leaked from the well. This indicates that the increase in calcium and carbonate due to dissolution of calcite in response to lowered $\mathrm{pH}$ in the aquifer has a stronger influence on TDS than the increase in $\mathrm{Na}$, chloride, and trace metals from the relatively smaller brine leak. The $\mathrm{pH}$ plume size is influenced by the $\mathrm{CO}_{2}$ leakage rate and the equilibrium coefficients for calcite and dolomite. Dissolution of $\mathrm{CO}_{2}$ in groundwater lowers the $\mathrm{pH}$, and dissolution/precipitation of calcite and dolomite also involve hydrogen ions $\left(\mathrm{H}^{+}\right)$. Both the As and Cd plumes are strongly influenced by the concentration of sodium chloride $(\mathrm{NaCl})$ in the brine, because the As and $\mathrm{Cd}$ concentrations in the brine are proportional to the $\mathrm{NaCl}$ concentrations. Sorption and secondary mineral precipitation seem to have little influence, likely because As and $\mathrm{Cd}$ exceed the threshold limits only for the highest values of brine leak rate and $\mathrm{NaCl}$ concentrations. The sizes of the lead plumes are influenced by the brine leak rate, $\mathrm{NaCl}$ concentration, and to a lesser extent the $\mathrm{CO}_{2}$ leak rate, equilibrium of calcite and dolomite, and the number of illite and kaolinite surface sites. The dependence on the $\mathrm{CO}_{2}$ leak rate and equilibrium coefficients for calcite and dolomite indicate a dependence on $\mathrm{pH}$, which would influence the amount of $\mathrm{Pb}$ sorbed on illite and kaolinite surface sites.

Polynomial nonlinear regression was used to develop the groundwater geochemistry ROM for the Edwards Aquifer that predicts the $\mathrm{pH}$, TDS, $\mathrm{As}, \mathrm{Cd}$, and $\mathrm{Pb}$ plume sizes, as well as the $\mathrm{CO}_{2}$ flux to the 
atmosphere with time. The $\mathrm{CO}_{2}$ flux to the atmosphere has the highest goodness-of-fit value $\left(\mathrm{R}^{2}\right)$ of 1 , because it is linearly correlated with the $\mathrm{CO}_{2}$ leak rate. Using the MCL limits, the $\mathrm{R}^{2}$ values for the plume volumes range from $0.87(\mathrm{Cd})$ to $0.95(\mathrm{As})$, while the $\mathrm{R}^{2}$ for the lengths and widths of the plumes are somewhat lower, ranging from 0.79 to 0.97 . For the lower no-impact threshold limits, the $\mathrm{R}^{2}$ values are similar for $\mathrm{pH}, \mathrm{Pb}$, and TDS plume volumes, but notably higher for the $\mathrm{As}$ and $\mathrm{Cd}$ plume volumes. Volumes of the plumes are strongly correlated with the $\mathrm{CO}_{2}$ and brine leak rates and cumulative mass leaked; while the lengths and widths of the plumes are also correlated with these variables, they are also influenced by the heterogeneous permeability and porosity of the aquifer. 



\section{Acknowledgments}

The contributions of scientists at the other national laboratories developing reduced-order models for the National Risk Assessment Partnership are gratefully acknowledged. Elizabeth Keating and Zhenxue Dai at Los Alamos National Laboratory (LANL) contributed their heterogeneous permeability and porosity field and model grid. Amy Jordan, Phil Stauffer and Zhenxue Dai of LANL developed the Wellbore Leakage model used as input for the modeling described in this report. The surface complexation reactions used in this report were compiled in collaboration with Liange Zheng of Lawrence Berkeley National Laboratory. Many thanks are also due to Susan Carrol, Kayum Mansoor and Yunwei Sun of Lawrence Livermore National Laboratory for their contributions to the NRAP Groundwater Protection Working Group. 



\section{Acronyms and Abbreviations}

As

CCM

$\mathrm{Cd}$

$\mathrm{Cl}$

$\mathrm{CO}_{2}$

DLM

EPA

$\mathrm{F}$

$\mu \mathrm{g} / \mathrm{L}$

$\mathrm{kg} / \mathrm{s}$

$\mathrm{km}$

k-s-p

$\mathrm{L}$

LANL

LBNL

$\mathrm{m}$

$\mathrm{m}^{3}$

MARS

$\mathrm{Mgal} / \mathrm{d}$

$\mathrm{mg} / \mathrm{L}$

MCL

$\mathrm{MPa}$

$\mathrm{Na}$

$\mathrm{NaCl}$

NRAP

$\mathrm{Pb}$

PNNL

$\mathrm{R}^{2}$

ROM

SCM

STOMP

TDS arsenic

constant capacitance model

cadmium

chorine

carbon dioxide

double layer model

U.S. Environmental Protection Agency

farads

microgram(s) per liter

kilogram(s) per second

kilometer(s)

permeability-saturation-capillary pressure

liter(s)

Los Alamos National Laboratory

Lawrence Berkeley National Laboratory

meter(s)

cubic meter(s)

multivariate adaptive regression splines

million gallons per day

milligram(s) per liter

maximum contaminant level

megapascal(s)

sodium

sodium chloride

National Risk Assessment Partnership

lead

Pacific Northwest National Laboratory

goodness-of-fit parameter

reduced-order model

surface complexation model

Subsurface Transport Over Multiple Phases

total dissolved solids 



\section{Contents}

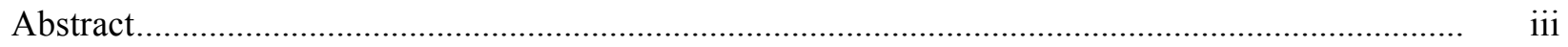

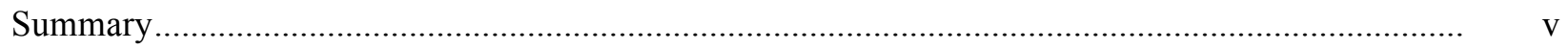

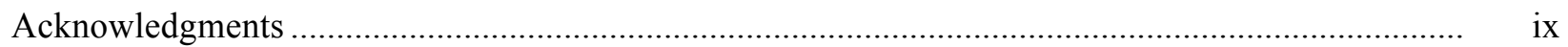

Acronyms and Abbreviations ............................................................................................... xi

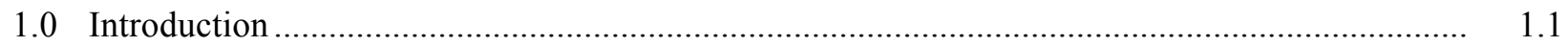

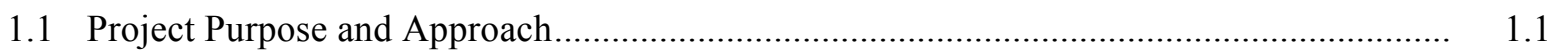

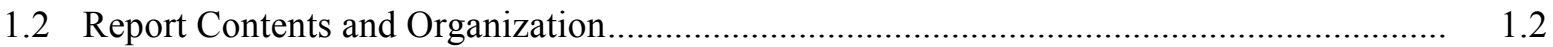

2.0 Study Site - Edwards Aquifer....................................................................................... 2.1

3.0 Edwards Aquifer Model .........................................................................................

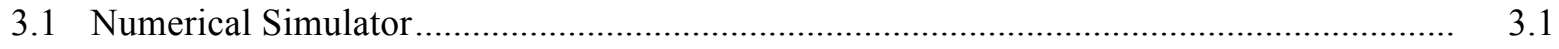

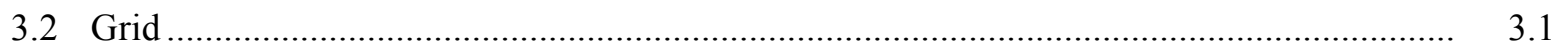

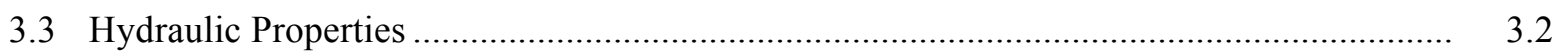

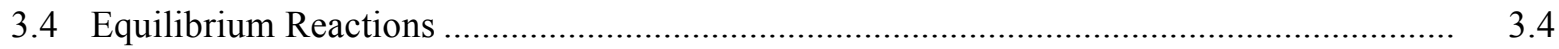

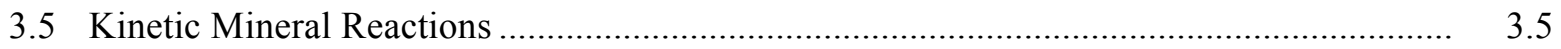

3.6 Surface Complexation Reactions .......................................................................... 3.6

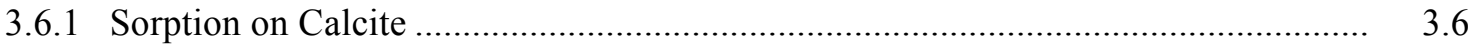

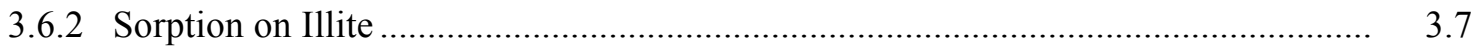

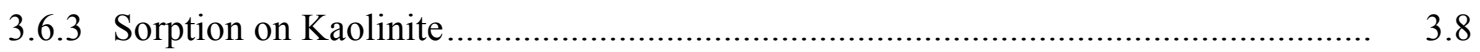

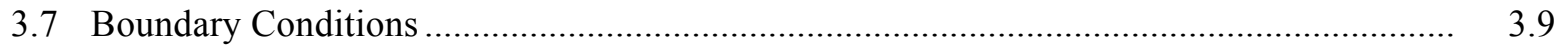

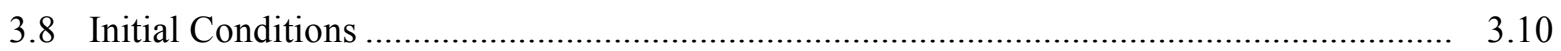

4.0 Well Leak Reduced-Order Model …........................................................................................ 4.1

5.0 Base-Case Model Results................................................................................................. 5.1

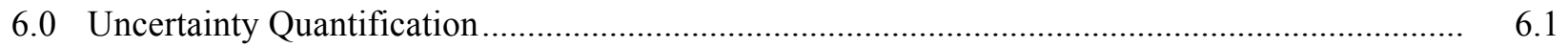

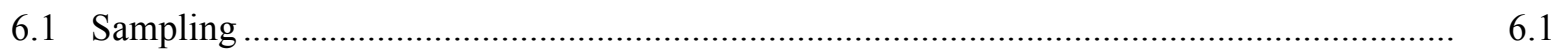

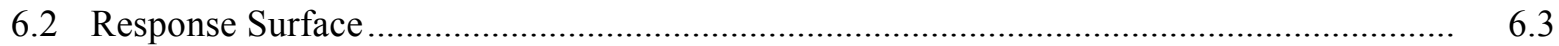

6.3 Transformation of the Response Surface ..................................................................... 6.7

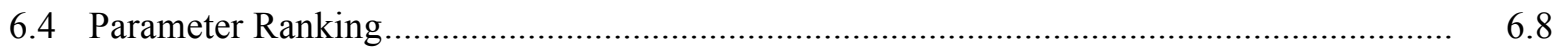

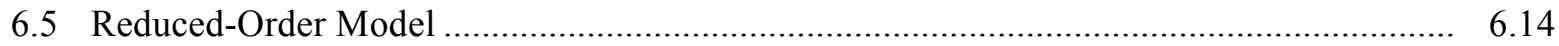

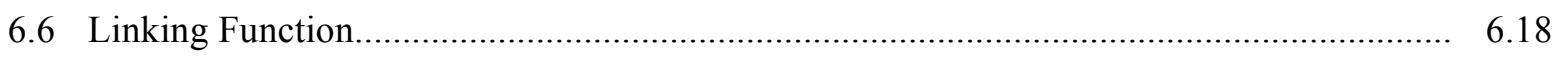

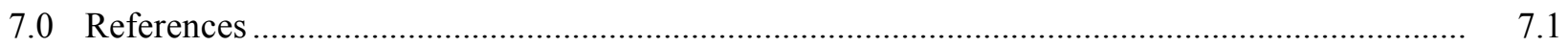




\section{Figures}

2.1 Piper diagram of major ion chemistry for the shallow urban unconfined portion of the Edwards Aquifer.

2.2 Hydrochemical facies of ninety water samples from the shallow, unconfined portion of the Edwards Aquifer.

3.1 Two-dimensional areal model grid of the Edwards Aquifer.

3.2 Porosity distribution in the Edwards Aquifer.

3.3 X-direction intrinsic permeability in the Edwards Aquifer.

3.4 Y-direction intrinsic permeability in the Edwards Aquifer.

4.1 $\mathrm{CO}_{2}$ leakage rate for median values of the Wellbore Leakage ROM input parameters.

4.2 Brine leakage rate for median values of the Wellbore Leakage ROM input parameters.

$5.1 \mathrm{pH}$ after 200 years of well leakage.

5.2 TDS after 200 years of well leakage.

5.3 Total aqueous arsenate after 200 years of well leakage.

5.4 Total cadmium concentration after 200 years of well leakage

5.5 Total lead concentration after 200 years of well leakage.

5.6 TDS plume volume, length and width during 200 years of well leakage.

$5.7 \mathrm{pH}$ plume volume, length and width during 200 years of well leakage.

5.8 Arsenic plume volume, length, and width during 200 years of well leakage. Arsenic does not exceed the MCL threshold for this simulation.

5.9 Cadmium plume volume, length, and width during 200 years of well leakage. Cadmium does not exceed the MCL threshold for this simulation.

5.10 Lead plume volume, length, and width during 200 years of well leakage.

5.11 Carbon dioxide flux to the atmosphere during 200 years of well leakage.

6.1 Well $\mathrm{CO}_{2}$ leakage rate vs. time for 1024 samples of input parameters.

6.2 Well brine leakage rate vs. time for 1024 samples of input parameters

6.3 Growth of $\mathrm{pH}$ plume volume, length, and width with time for 1024 samples using MCL limits.

6.4 Growth of $\mathrm{pH}$ plume volume, length, and width with time for 1024 samples using no-impact limits.

6.5 Growth of TDS plume volume, length, and width with time for 1024 samples using MCL limits.

6.6 Growth of TDS plume volume, length, and width with time for 1024 samples using no-impact limits.

6.7 Growth of As plume volume, length, and width with time for 1024 samples using MCL limits.

6.8 Growth of As plume volume, length, and width with time for 1024 samples using no-impact limits.

6.9 Growth of Cd plume volume, length, and width with time for 1024 samples using MCL limits. 
6.10 Growth of Cd plume volume, length, and width with time for 1024 samples using no-impact limits.

6.11 Growth of $\mathrm{Pb}$ plume volume, length, and width with time for 1024 samples using MCL limits.

6.12 Growth of $\mathrm{Pb}$ plume volume, length, and width with time for 1024 samples using no-impact limits.

$6.13 \mathrm{CO}_{2}$ flux to atmosphere with time for 1024 samples using MCL limits.

6.14 Input parameter ranking for TDS plume size using MCL limits.

6.15 Input parameter ranking for TDS plume size using no-impact limits

6.16 Input parameter ranking for $\mathrm{pH}$ plume size using MCL limits.

6.17 Input parameter ranking for $\mathrm{pH}$ plume size using no-impact limits

6.18 Input parameter ranking for As plume size using MCL limits

6.19 Input parameter ranking for As plume size using no-impact limits.

6.20 Input parameter ranking for Cd plume size using MCL limits.

6.21 Input parameter ranking for $\mathrm{Cd}$ plume size using no-impact limits.

6.22 nput parameter ranking for $\mathrm{Pb}$ plume size using MCL limits.

6.23 Input parameter ranking for $\mathrm{Pb}$ plume size using no-impact limits.

6.24 Input parameter ranking for $\mathrm{CO}_{2}$ flux to atmosphere.

6.25 Comparison of $\mathrm{CO}_{2}$ flux to the atmosphere predicted by ROM and STOMP.

6.26 Comparison of TDS plume sizes predicted by ROM and STOMP using MCL limits.

6.27 Comparison of TDS plume sizes predicted by ROM and STOMP using no-impact limits.

6.29 Comparison of $\mathrm{pH}$ plume sizes predicted by ROM and STOMP using no-impact limits.

6.31 Comparison of As plume sizes predicted by ROM and STOMP using no-impact limits

6.32 Comparison of Cd plume sizes predicted by ROM and STOMP using MCL limits.

6.33. Comparison of Cd plume sizes predicted by ROM and STOMP using no-impact limits

6.34 Comparison of $\mathrm{Pb}$ plume sizes predicted by ROM and STOMP using MCL limits.

6.35 Comparison of $\mathrm{Pb}$ plume sizes predicted by ROM and STOMP using no-impact limits.

6.18

6.36 Comparison of response variables predicted by simple and complex geochemical models using no-impact threshold limits. 


\section{Tables}

2.1 nitial values, tolerance limits, and regulatory standards for each variable ............................... 2.3

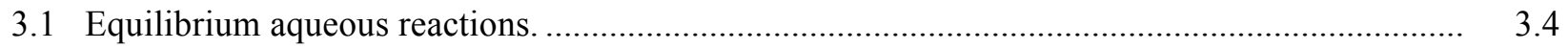

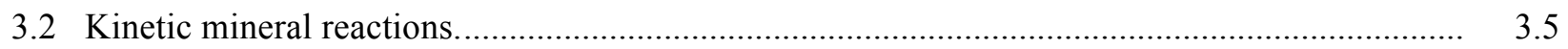

3.3 Surface protonation and complexation reactions of anions on calcite. ..................................... 3.6

3.4 Surface protonation and complexation reactions of cations on illite. ....................................... 3.7

3.5 Surface protonation and complexation of oxyanions on illite................................................ 3.8

3.6 Surface protonation and complexation reactions of cations on kaolinite ................................... 3.9

3.7 Surface protonation and complexation reactions of anions on kaolinite................................... 3.9

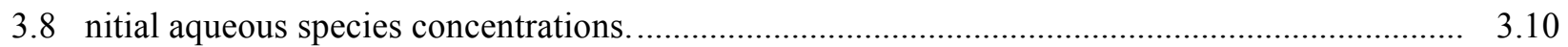

4.1 Input parameters for Wellbore Leakage ROM......................................................................

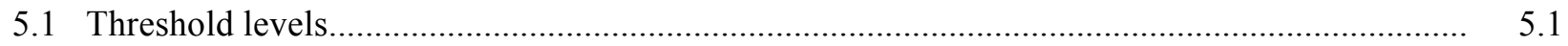

6.1 Input parameters and their ranges for uncertainty quantification............................................. 6.1

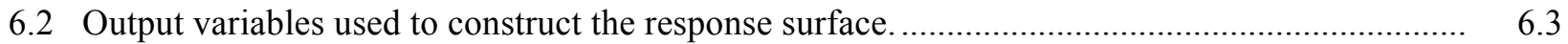

6.3 Percentage of 1024 samples resulting in plumes exceeding threshold limits or $\mathrm{CO}_{2}$ flux to

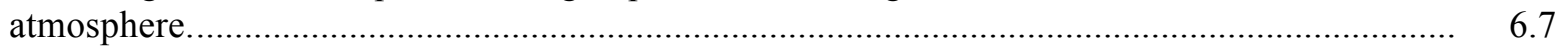

6.4 Transformed input parameters and their ranges for uncertainty quantification. ........................... 6.8

6.5 Regression goodness of fit for each output variable. ............................................................. 6.15

6.6 Equilibrium aqueous reactions for simple geochemical model.............................................. 6.18 


\subsection{Introduction}

The National Risk Assessment Partnership (NRAP) is a U.S. Department of Energy-funded program to develop and demonstrate a methodology and toolset for predicting long-term risk profiles needed for quantifying potential liabilities at a carbon dioxide $\left(\mathrm{CO}_{2}\right)$ storage project. Five national laboratories are participating in the partnership: the National Energy Technology Laboratory (NETL), Lawrence Berkeley National Laboratory (LBNL), Los Alamos National Laboratory (LANL), Lawrence Livermore National Laboratory (LLNL) and Pacific Northwest National Laboratory (PNNL).

Potential risks at $\mathrm{CO}_{2}$ storage sites include the return of $\mathrm{CO}_{2}$ to the atmosphere, impacts on groundwater chemistry, and induced seismic events. The return of $\mathrm{CO}_{2}$ to the atmosphere could result in the loss of carbon credits. Impacts on groundwater relate to exceeding regulatory limits for groundwater contaminants.

\subsection{Project Purpose and Approach}

The approach taken by NRAP is to divide the system into components, including injection target reservoirs, wellbores, natural pathways including faults and fractures, groundwater, and the atmosphere. Next, a detailed, physics- and chemistry-based model of each component is developed. Using the results of the detailed models, efficient, simplified models, termed reduced-order models (ROMs) are developed for each component. Finally, the component ROMs are integrated into a system model that calculates risk profiles for the site.

The groundwater component models are based on two sites: the confined, reducing sandstone High Plains Aquifer, which extends between South Dakota and Texas, and the unconfined, oxidizing carbonate Edwards Aquifer of south-central Texas. Two ROMs have been developed for each aquifer, one with varied hydraulic parameters, and another with varied geochemical parameters, resulting in four separate groundwater ROMs. This report focuses on PNNL's development of the groundwater geochemistry ROM for the Edwards Aquifer.

The approach used to develop the groundwater geochemistry ROM for the Edwards Aquifer was to develop a complex model of groundwater flow and reactive transport in the shallow, urban unconfined portion of the aquifer near San Antonio, Texas. This model, using the STOMP (Subsurface Transport Over Multiple Phases) simulator, used a Wellbore Leakage ROM provided by LANL to calculate $\mathrm{CO}_{2}$ and brine leakage rates into the aquifer. The STOMP model included equilibrium, kinetic mineral, and adsorption reactions related to the carbonate and clay minerals in the aquifer reacting with major ions and trace metals in groundwater, as well as $\mathrm{CO}_{2}$ and brine containing sodium $(\mathrm{Na})$, chloride $(\mathrm{Cl})$, arsenic $(\mathrm{As})$, cadmium $(\mathrm{Cd})$, and lead $(\mathrm{Pb})$ leaking from the wellbore.

Using Latin Hypercube sampling, a number of geochemical parameters and wellbore ROM parameters were varied to generate 1024 random samples. STOMP was run 1024 times to calculate $\mathrm{pH}$, total dissolved solids (TDS), and $\mathrm{As}, \mathrm{Cd}$, and $\mathrm{Pb}$ concentrations in the groundwater, as well as the $\mathrm{CO}_{2}$ flux to the atmosphere across the water table. Based on this, the size of the affected volume of the aquifer based on regulatory limits was calculated. The size of the $\mathrm{pH}$, TDS, As, $\mathrm{Cd}$, and $\mathrm{Pb}$ plumes, along with the $\mathrm{CO}_{2}$ flux to the atmosphere, compose the response of the aquifer to variations in model input parameters. Important input parameters were identified using multivariate adaptive regression splines 
(MARS) parameter ranking. Polynomial nonlinear regression was used to develop the groundwater geochemistry ROM for the Edwards Aquifer that predicts the $\mathrm{pH}$, TDS, As, Cd, and Pb plume sizes, as well as the $\mathrm{CO}_{2}$ flux to the atmosphere with time.

\subsection{Report Contents and Organization}

The ensuing sections of this report describe the site of the Edwards Aquifer and related studies and water sampling (Section 2.0), the development of the Edwards Aquifer model (Section 3.0), and the use of a well leakage ROM (Section 4.0). Base-case model results and the uncertainty quantification process are described in Sections 5.0 and 6.0, respectively. 


\subsection{Study Site - Edwards Aquifer}

The Edwards Aquifer in south-central Texas is one of the most productive karst aquifers in the world (Musgrove et al. 2010). The U.S. Environmental Protection Agency (EPA) designated the Edwards Aquifer as a sole-source aquifer in the San Antonio area, where it provides water to more than two million people. The total groundwater withdrawal from the Edwards Aquifer system in 2000 was $740 \mathrm{Mgal} / \mathrm{d}$ of which withdrawal for public supply was $411 \mathrm{Mgal} / \mathrm{d}$.

As part of the National Water-Quality Assessment Program, the U.S. Geological Survey collected and analyzed groundwater samples from 1996 to 2006 from the San Antonio segment of the Edwards Aquifer of central Texas, a productive karst aquifer developed in Cretaceous-age carbonate rocks (Musgrove et al. 2010). The National Water-Quality Assessment Program studies provide an extensive data set of groundwater geochemistry and water quality, consisting of 249 groundwater samples collected from 136 sites (wells and springs), including

1. wells completed in the shallow, unconfined, and urbanized part of the aquifer in the vicinity of San Antonio (shallow/urban unconfined category)

2. wells completed in the unconfined (outcrop area) part of the regional aquifer (unconfined category)

3. wells completed in and springs discharging from the confined part of the regional aquifer (confined category)

Ninety water samples from the shallow, unconfined portion of the Edwards Aquifer in Texas (Musgrove et al. 2010) were plotted on a Piper diagram (Figure 2.1) to determine their hydrogeochemical facies (Figure 2.2) (Back 1966; Bartos and Ogle 2002). All samples are calcium bicarbonate-type waters. 


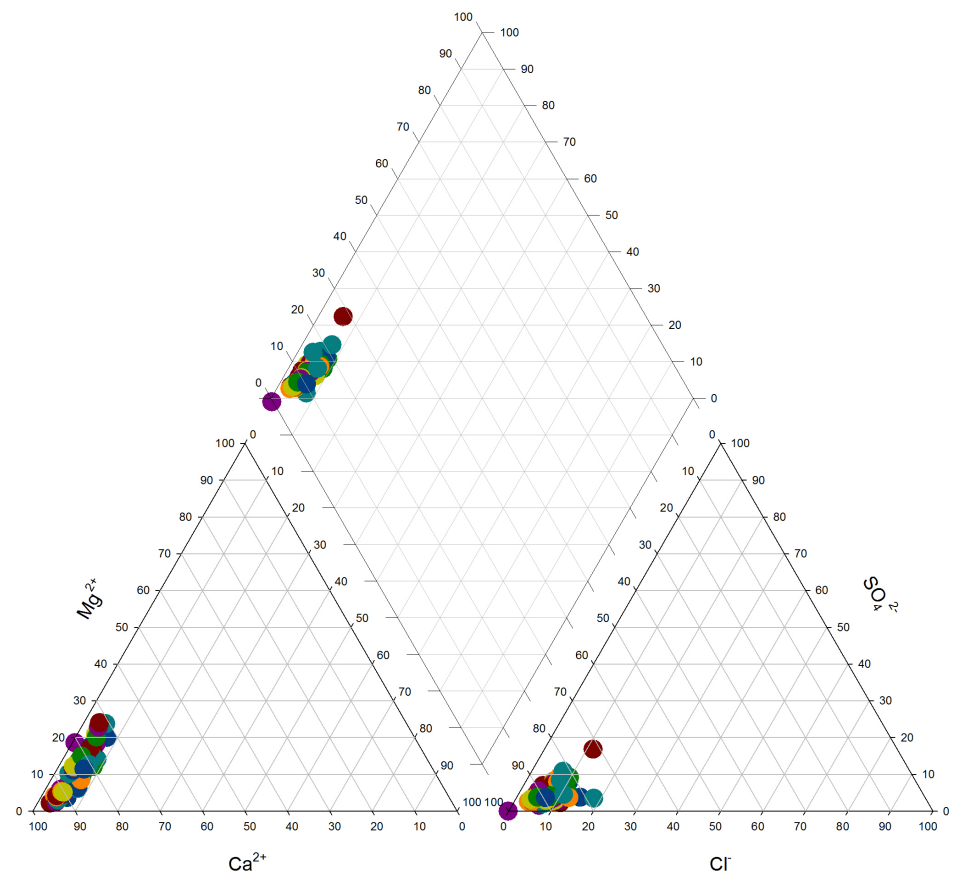

Figure 2.1. Piper diagram of major ion chemistry for the shallow urban unconfined portion of the Edwards Aquifer.

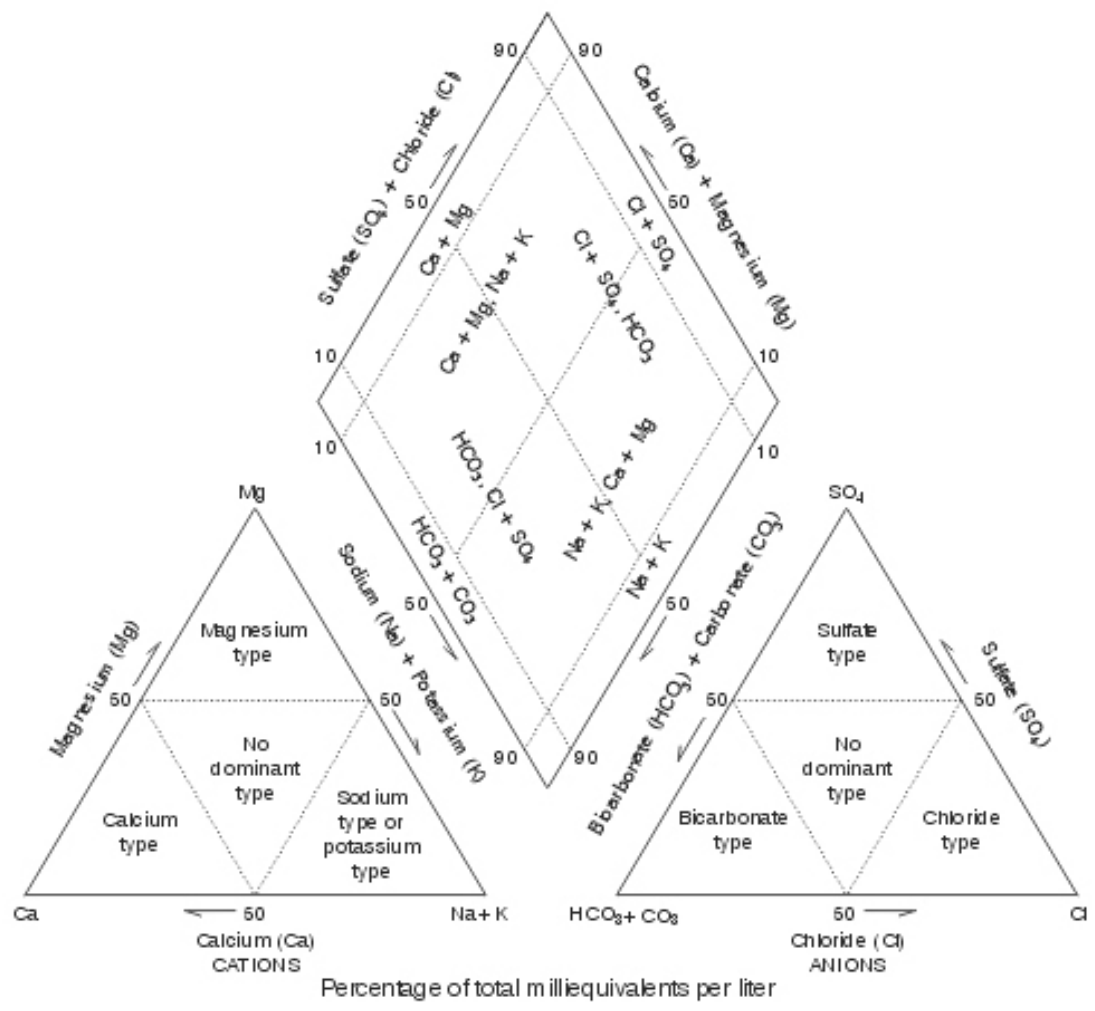

Figure 2.2. Hydrochemical facies of ninety water samples from the shallow, unconfined portion of the Edwards Aquifer. 
This set of water samples was used to examine methodologies for establishing baseline data sets and statistical protocols for determining statistically significant changes between background concentrations and predicted concentrations that would be used to represent a contamination plume in the modeling presented in this report (Last et al. 2013). No-impact threshold values were determined for $\mathrm{Cd}, \mathrm{Pb}, \mathrm{As}$, $\mathrm{pH}$, and TDS that could be used to identify potential areas of contamination predicted by numerical models of carbon sequestration storage reservoirs (Table 2.1). Initial values of these concentrations were also determined using selected statistical methods. For comparison, the EPA maximum contaminant level (MCL) is also shown.

Table 2.1. Initial values, tolerance limits, and regulatory standards for each variable.

\begin{tabular}{|c|c|c|c|c|}
\hline Analyte & Initial Value $^{(\mathrm{a})}$ & "No-Impact" Threshold ${ }^{(\mathrm{a})}$ & Maximum Contaminant Level & Units \\
\hline Arsenic & 0.31 & 0.55 & 10 & $\mu \mathrm{g} / \mathrm{L}$ \\
\hline Cadmium & 0 & 0.04 & 5 & $\mu \mathrm{g} / \mathrm{L}$ \\
\hline Lead & 0.064 & 0.15 & 15 & $\mu \mathrm{g} / \mathrm{L}$ \\
\hline $\mathrm{pH}$ & 6.9 & 6.6 & 6.5 & $-\log \left[\mathrm{H}^{+}\right]$ \\
\hline TDS & 330 & 420 & 500 & $\mathrm{mg} / \mathrm{L}$ \\
\hline
\end{tabular}





\subsection{Edwards Aquifer Model}

\subsection{Numerical Simulator}

The simulations conducted for this investigation were executed with the STOMP-CO2 (water, $\mathrm{CO}_{2}$, salt) simulator (White and Oostrom 2006). Partial differential conservation equations for fluid mass and salt mass compose the fundamental equations for STOMP-CO2. Coefficients within the fundamental equations are related to the primary variables through a set of constitutive relations. The conservation equations for fluid mass and energy are solved simultaneously, whereas the salt transport equations are solved sequentially after the coupled flow solution. The fundamental coupled flow equations are solved following an integral volume finite-difference approach with the nonlinearities in the discretized equations resolved through Newton-Raphson iteration.

The dominant nonlinear functions within the STOMP simulator are the relative permeabilitysaturation-capillary pressure (k-s-p) relations. The STOMP simulator allows the user to specify these relations through a large variety of popular and classic functions. Two-phase (gas-aqueous) k-s-p relations can be specified with hysteretic or nonhysteretic functions or nonhysteretic tabular data. Entrapment of $\mathrm{CO}_{2}$ with imbibing water conditions can be modeled with the hysteretic two-phase k-s-p functions (White et al. 2004). Two-phase k-s-p relations span both saturated and unsaturated conditions. The aqueous phase is assumed to never completely disappear through extensions to the s-p function below the residual saturation and a vapor-pressure-lowering scheme. Supercritical $\mathrm{CO}_{2}$ has the role of a gas in these two-phase k-s-p relations.

The chemistry module ECKEChem (Equilibrium-Conservation-Kinetic-Equation Chemistry) solves mass balance equations, mass action equations, and kinetic equations simultaneously using the NewtonRaphson approach (White and McGrail 2005). STOMP has been verified against other codes used for simulation of geologic disposal of $\mathrm{CO}_{2}$ as part of the GeoSeq code comparison study (Pruess et al. 2004), and has been used in previous investigations of $\mathrm{CO}_{2}$ injection potential at several sites (Bacon et al. 2009a; Bacon et al. 2009b; Barnes et al. 2009).

\subsection{Grid}

A two-dimensional, heterogeneous model of groundwater flow and reactive transport in the Edwards Aquifer has been developed in collaboration with LANL. The model focuses on a shallow, unconfined portion of the aquifer near San Antonio, Texas. The aquifer is assumed to be $150 \mathrm{~m}$ thick, and we focus on an $8-\mathrm{km} \times 5-\mathrm{km}$ area (Figure 3.1). The grid is refined at the assumed leak point at $X=2500 \mathrm{~m}$, $\mathrm{Y}=7000 \mathrm{~m}$. There are 38 grid cells in the $\mathrm{X}$-direction and 35 cells in the Y-direction. A twodimensional grid was used for the generation 2.0 model to reduce long run times caused by the increased complexity of the geochemical reaction network. This was assumed to be a reasonable simplification, because for the 512 simulations conducted for the first generation ROM, all $\mathrm{CO}_{2}$ plumes rose to the full height of the aquifer early in the simulation, between 10 and 40 years. 


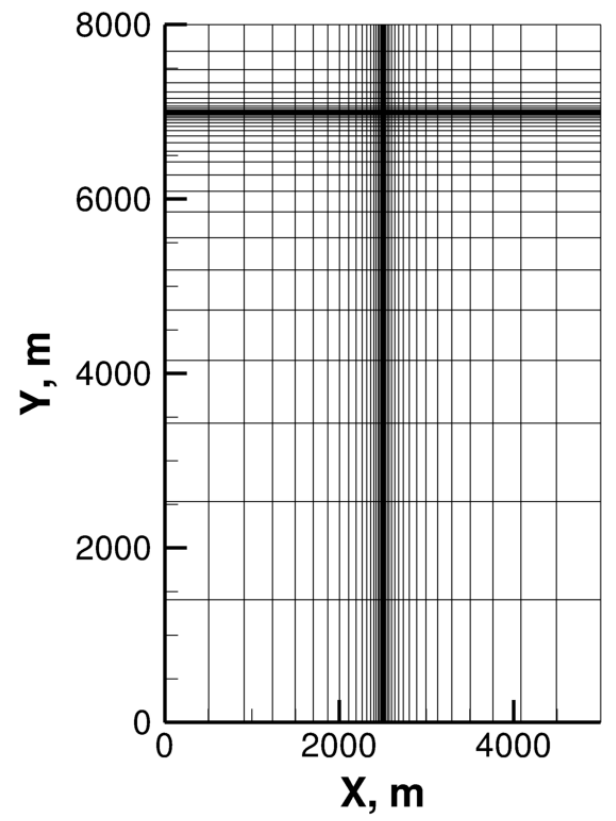

Figure 3.1. Two-dimensional areal model grid of the Edwards Aquifer.

\subsection{Hydraulic Properties}

LANL provided a three-dimensional stochastic realization of porosity and permeability for the model domain on a $38-\times 35-\times 10$-cell grid. The porosity and permeability were upscaled to the twodimensional 38- $\times 35-\times 1$-cell grid. Volume averaging was used for porosity (Figure 3.2 ) and the principal components of the upscaled permeability tensor (Figure 3.3 and Figure 3.4) were computed as the geometric mean of the Cardwell and Parsons bounds (Cardwell and Parsons 1945; Li et al. 2001).

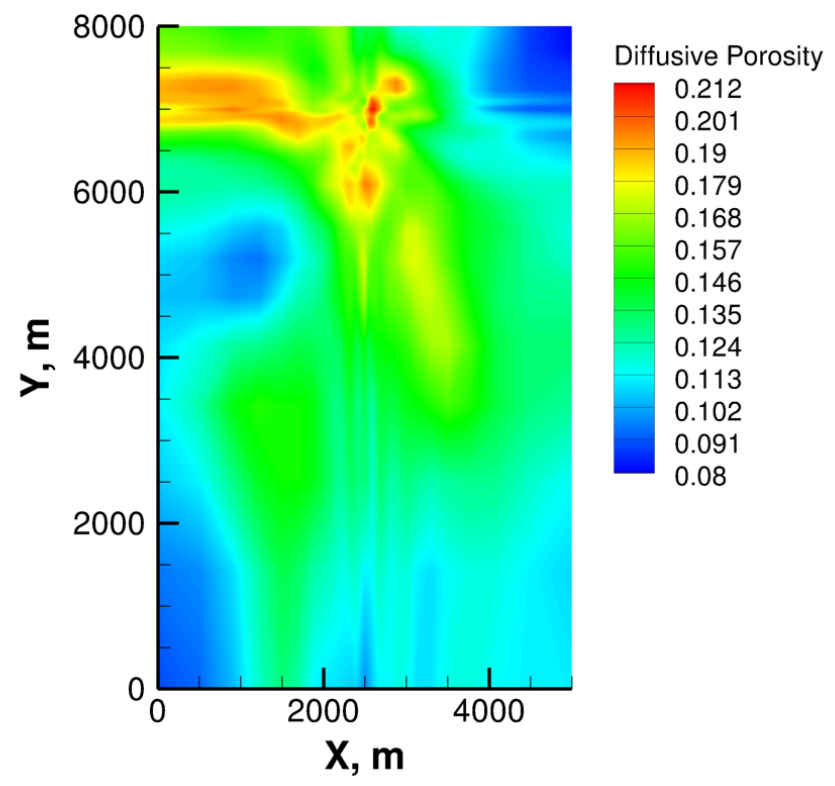

Figure 3.2. Porosity distribution in the Edwards Aquifer. 


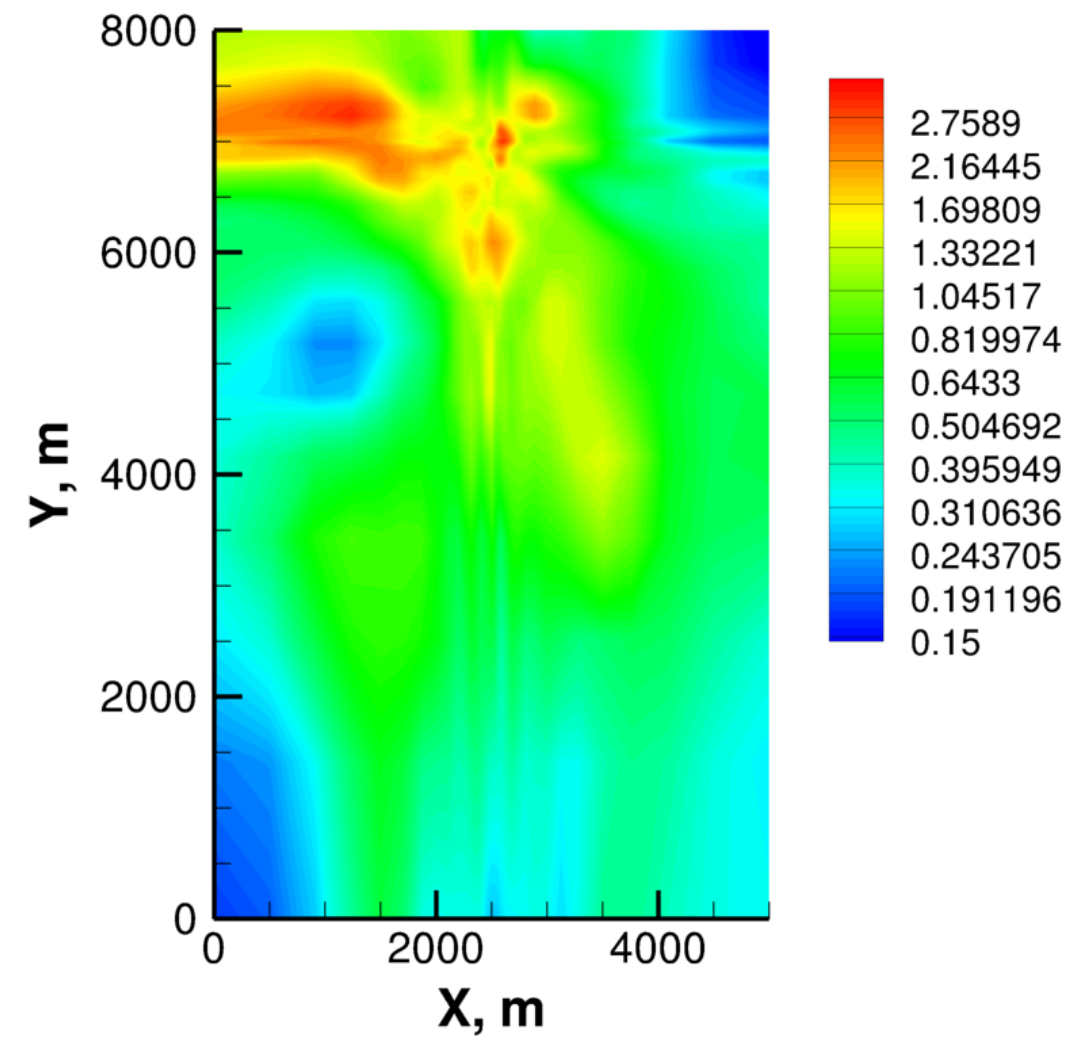

Figure 3.3. X-direction intrinsic permeability $\left(\mathrm{m}^{2}\right)$ in the Edwards Aquifer.

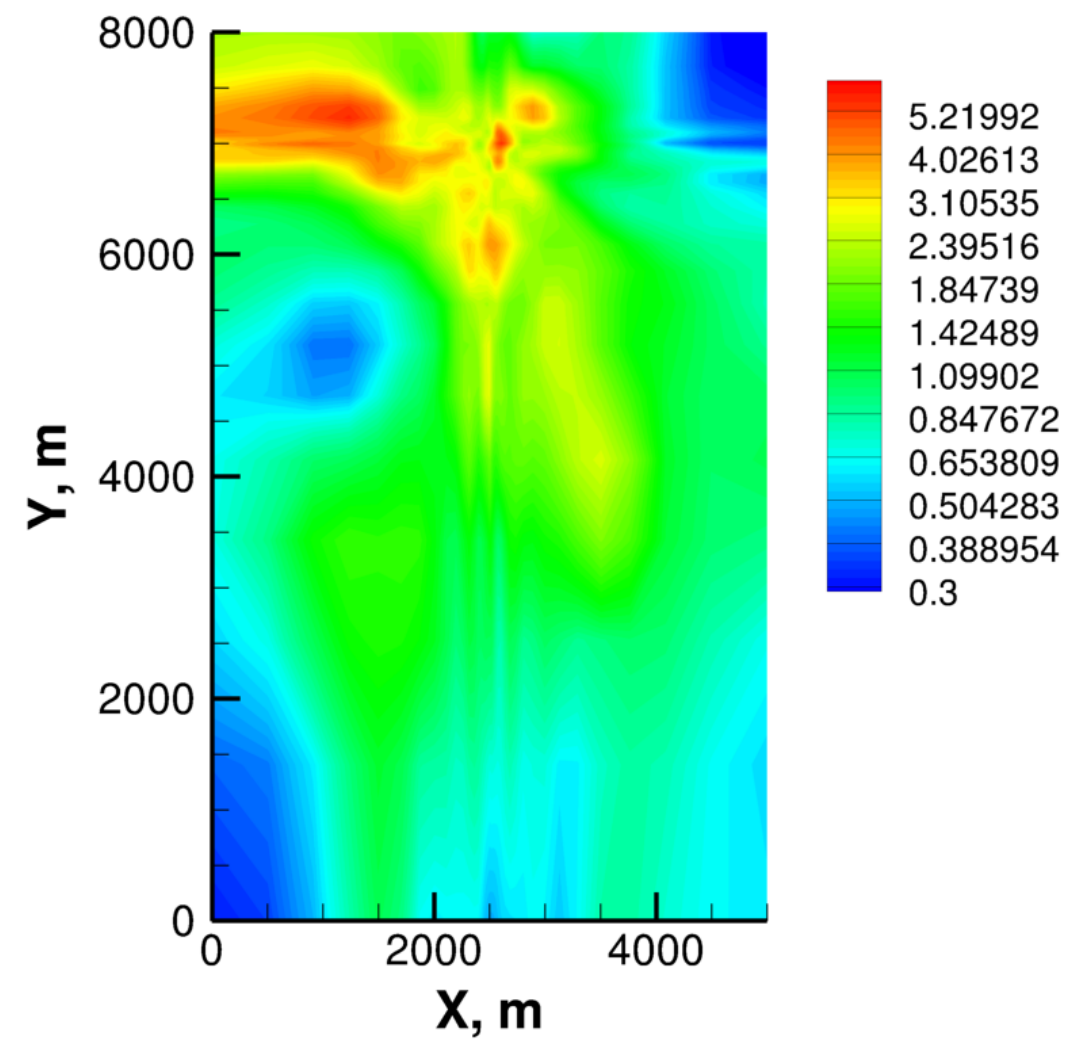

Figure 3.4. Y-direction intrinsic permeability $\left(\mathrm{m}^{2}\right)$ in the Edwards Aquifer. 


\subsection{Equilibrium Reactions}

The same 90 water samples were modeled using PHREEQC (Parkhurst and Appelo 1999) using the THERMODDEM database (Blanc et al. 2012) to determine the significant equilibrium aqueous reactions involving the elements $\mathrm{Ca}, \mathrm{Mg}, \mathrm{K}, \mathrm{Na}, \mathrm{Cl}, \mathrm{F}, \mathrm{S}, \mathrm{Si}, \mathrm{O}, \mathrm{C}, \mathrm{P}, \mathrm{Al}, \mathrm{Fe}, \mathrm{As}, \mathrm{Cd}$, and $\mathrm{Pb}$. The relevant equilibrium aqueous reactions are listed in Table 3.1.

Table 3.1. Equilibrium aqueous reactions.

\begin{tabular}{|c|c|}
\hline Equilibrium Reaction & $\begin{array}{l}\text { Equilibrium Coefficient at } 25^{\circ} \mathrm{C}, \\
\log \end{array}$ \\
\hline $\mathrm{Al}^{3+}+\mathrm{F}^{-}+2 \mathrm{H}_{2} \mathrm{O}=\mathrm{Al}(\mathrm{OH})_{2} \mathrm{~F}+2 \mathrm{H}^{+}$ & -4.214 \\
\hline $\mathrm{Al}^{3+}+\mathrm{H}_{2} \mathrm{O}=\mathrm{AlOH}^{+2}+\mathrm{H}^{+}$ & -4.950 \\
\hline $\mathrm{Al}^{3+}+\mathrm{H}_{4} \mathrm{SiO}_{4}=\mathrm{AlH}_{3} \mathrm{SiO}^{+2}+\mathrm{H}^{+}$ & -2.380 \\
\hline $\mathrm{Al}^{3+}+2 \mathrm{~F}^{-}+2 \mathrm{H}_{2} \mathrm{O}=\mathrm{Al}(\mathrm{OH})_{2} \mathrm{~F}_{2}^{-}+2 \mathrm{H}^{+}$ & -1.987 \\
\hline $\mathrm{Al}^{3+}+2 \mathrm{H}_{2} \mathrm{O}=\mathrm{AlO}_{2}^{-}+4 \mathrm{H}^{+}$ & -22.870 \\
\hline $\mathrm{Al}^{3+}+2 \mathrm{H}_{2} \mathrm{O}=\mathrm{Al}(\mathrm{OH})_{2}^{+}+2 \mathrm{H}^{+}$ & -10.590 \\
\hline $\mathrm{Al}^{3+}+2 \mathrm{H}_{2} \mathrm{O}=\mathrm{HAlO}_{2}+3 \mathrm{H}^{+}$ & -16.420 \\
\hline $\mathrm{Ca}^{2+}+\mathrm{Cl}^{-}=\mathrm{CaCl}^{+}$ & -0.290 \\
\hline $\mathrm{Ca}^{2+}+\mathrm{F}^{-}=\mathrm{CaF}^{+}$ & 0.719 \\
\hline $\mathrm{Ca}^{2+}+\mathrm{H}_{2} \mathrm{PO}_{4}^{-}=\mathrm{CaH}_{2} \mathrm{PO}_{4}^{+}$ & 1.500 \\
\hline $\mathrm{Ca}^{2+}+\mathrm{H}_{2} \mathrm{PO}_{4}^{-}=\mathrm{CaHPO}_{4}+\mathrm{H}^{+}$ & -4.370 \\
\hline $\mathrm{Ca}^{2+}+\mathrm{H}_{2} \mathrm{PO}_{4}^{-}=\mathrm{CaPO}_{4}^{-}+2 \mathrm{H}^{+}$ & -13.110 \\
\hline $\mathrm{Ca}^{2+}+\mathrm{SO}_{4}^{2-}=\mathrm{CaSO}_{4}$ & 2.310 \\
\hline $\mathrm{Cd}^{2+}+\mathrm{Cl}^{-}=\mathrm{CdCl}^{+}$ & 1.970 \\
\hline $\mathrm{Cd}^{2+}+\mathrm{SO}_{4}{ }^{2-}=\mathrm{CdSO}_{4}$ & 3.440 \\
\hline $\mathrm{Cl}^{-}+\mathrm{Mg}^{2+}=\mathrm{MgCl}^{+}$ & 0.350 \\
\hline $\mathrm{F}^{-}+\mathrm{Mg}^{2+}=\mathrm{MgF}^{+}$ & 1.149 \\
\hline $\mathrm{Fe}^{2+}+\mathrm{H}_{2} \mathrm{O}=\mathrm{FeOH}^{+}+\mathrm{H}^{+}$ & -9.500 \\
\hline $\mathrm{Fe}^{2+}+\mathrm{H}_{2} \mathrm{PO}_{4}^{-}=\mathrm{FeHPO}_{4}+\mathrm{H}^{+}$ & -3.608 \\
\hline $\mathrm{Fe}^{2+}+\mathrm{SO}_{4}{ }^{2-}=\mathrm{FeSO}_{4}$ & 2.244 \\
\hline $\mathrm{H}_{2} \mathrm{AsO}_{4}^{-}+\mathrm{Ca}^{2+}=\mathrm{CaH}_{2} \mathrm{AsO}_{4}^{+}$ & 1.398 \\
\hline $\mathrm{H}_{2} \mathrm{AsO}_{4}^{-}+\mathrm{Ca}^{2+}=\mathrm{CaHAsO}_{4}+\mathrm{H}^{+}$ & -4.080 \\
\hline $\mathrm{H}_{2} \mathrm{AsO}_{4}^{-}+\mathrm{H}^{+}=\mathrm{H}_{3} \mathrm{AsO}_{4}$ & 2.302 \\
\hline $\mathrm{H}_{2} \mathrm{AsO}_{4}^{-}+\mathrm{Mg}^{2+}=\mathrm{MgAsO}_{4}^{-}+2 \mathrm{H}^{+}$ & -12.735 \\
\hline $\mathrm{H}_{2} \mathrm{AsO}_{4}^{-}+\mathrm{Mg}^{2+}=\mathrm{MgH}_{2} \mathrm{AsO}_{4}^{+}$ & 1.512 \\
\hline $\mathrm{H}_{2} \mathrm{AsO}_{4}^{-}+\mathrm{Mg}^{2+}=\mathrm{MgHAsO}_{4}+\mathrm{H}^{+}$ & -4.539 \\
\hline $\mathrm{H}_{2} \mathrm{AsO}_{4}^{-}=\mathrm{HAsO}_{4}^{2-}+\mathrm{H}^{+}$ & -6.960 \\
\hline $\mathrm{H}_{2} \mathrm{O}=\mathrm{OH}^{-}+\mathrm{H}^{+}$ & -14.001 \\
\hline $\mathrm{H}_{2} \mathrm{PO}_{4}^{-}=\mathrm{HPO}_{4}^{2-}+\mathrm{H}^{+}$ & -7.212 \\
\hline $\mathrm{H}_{4} \mathrm{SiO}_{4}=\mathrm{HSiO}_{3}^{-}+\mathrm{H}_{2} \mathrm{O}+\mathrm{H}^{+}$ & -9.820 \\
\hline $\mathrm{HCO}_{3}{ }^{-}+\mathrm{Ca}^{2+}=\mathrm{CaCO}_{3}+\mathrm{H}^{+}$ & -7.107 \\
\hline $\mathrm{HCO}_{3}{ }^{-}+\mathrm{Ca}^{2+}=\mathrm{Ca}\left(\mathrm{HCO}_{3}\right)^{+}$ & 1.103 \\
\hline $\mathrm{HCO}_{3}{ }^{-}+\mathrm{Cd}^{2+}=\mathrm{CdCO}_{3}+\mathrm{H}^{+}$ & -5.627 \\
\hline
\end{tabular}


Table 3.1. (contd)

\begin{tabular}{lc}
\hline \multicolumn{1}{c}{ Equilibrium Reaction } & Equilibrium Coefficient at $25^{\circ} \mathrm{C}$, \\
\hline $\mathrm{HCO}_{3}{ }^{-}+\mathrm{Cd}^{2+}=\mathrm{CdHCO}_{3}{ }^{+}$ & 1.503 \\
$\mathrm{HCO}_{3}{ }^{-}+\mathrm{Fe}^{2+}+\mathrm{H}_{2} \mathrm{O}=\mathrm{FeCO}_{3} \mathrm{OH}^{-}+2 \mathrm{H}^{+}$ & -14.358 \\
$\mathrm{HCO}_{3}{ }^{-}+\mathrm{Fe}^{2+}=\mathrm{FeCO}_{3}+\mathrm{H}^{+}$ & -4.637 \\
$\mathrm{HCO}_{3}{ }^{-}+\mathrm{Fe}^{2+}=\mathrm{FeHCO}_{3}{ }^{+}$ & 1.440 \\
$\mathrm{HCO}_{3}{ }^{-}+\mathrm{H}^{+}=\mathrm{CO}_{2}+\mathrm{H}_{2} \mathrm{O}$ & 6.353 \\
$\mathrm{HCO}_{3}{ }^{-}+\mathrm{Mg}^{2+}=\mathrm{MgCO}_{3}+\mathrm{H}^{+}$ & -7.347 \\
$\mathrm{HCO}_{3}{ }^{-}+\mathrm{Mg}^{2+}=\mathrm{Mg}\left(\mathrm{HCO}_{3}\right)^{+}$ & 1.038 \\
$\mathrm{HCO}_{3}{ }^{-}+\mathrm{Na}^{+}=\mathrm{NaHCO}_{3}$ & -0.247 \\
$\mathrm{HCO}_{3}{ }^{-}+\mathrm{Pb}^{2+}=\mathrm{Pb}_{\left(\mathrm{CO}_{3}\right)}+\mathrm{H}^{+}$ & -3.327 \\
$\mathrm{HCO}_{3}{ }^{-}+\mathrm{Pb}^{2+}=\mathrm{PbHCO}_{3}{ }^{+}$ & 3.443 \\
$\mathrm{HCO}_{3}{ }^{-}=\mathrm{CO}_{3}{ }^{2-}+\mathrm{H}^{+}$ & -10.327 \\
$\mathrm{~K}^{+}+\mathrm{SO}_{4}{ }^{2-}=\mathrm{KSO}_{4}^{-}$ & 0.880 \\
$\mathrm{Mg}^{2+}+\mathrm{H}_{2} \mathrm{PO}_{4}{ }^{-}=\mathrm{MgH}_{2} \mathrm{PO}_{4}{ }^{+}$ & 1.170 \\
$\mathrm{Mg}^{2+}+\mathrm{H}_{2} \mathrm{PO}_{4}{ }^{-}=\mathrm{MgHPO}_{4}+\mathrm{H}^{+}$ & -4.303 \\
$\mathrm{Mg}^{2+}+\mathrm{SO}_{4}{ }^{2-}=\mathrm{MgSO}_{4}$ & 2.230 \\
$\mathrm{Na}^{+}+\mathrm{SO}^{2-}=\mathrm{NaSO}_{4}^{-}$ & 0.936 \\
$\mathrm{~Pb}^{2+}+\mathrm{H}_{2} \mathrm{O}=\mathrm{PbOH}^{+}+\mathrm{H}^{+}$ & -7.510 \\
$\mathrm{~Pb}^{2+}+\mathrm{SO}_{4}{ }^{2-}=\mathrm{PbSO}_{4}$ & 2.820 \\
$2 \mathrm{HCO}_{3}{ }^{-}+\mathrm{Pb}^{2+}=\mathrm{Pb}^{-}\left(\mathrm{CO}_{3}\right)_{2}{ }^{2-}+2 \mathrm{H}^{+}$ & -10.524 \\
\hline
\end{tabular}

\subsection{Kinetic Mineral Reactions}

The Edwards limestone consists mostly of calcite and dolomite (Pittman 1959), but little information is available on the minor minerals in the limestone. Illite and kaolinite are identified as clay minerals in suspended sediment at Barton Springs (Lynch et al. 2007).

For the model, the aquifer is assumed to consist mainly of calcite with up to $5 \%$ by volume each of dolomite, illite, and kaolinite (Table 3.2). Cerussite and otavite are included as potential secondary carbonate minerals.

Table 3.2. Kinetic mineral reactions.

\begin{tabular}{lccc}
\hline \multicolumn{1}{c}{ Kinetic Reaction } & $\begin{array}{c}\text { Equilibrium Coefficient } \\
\text { at } 25^{\circ} \mathrm{C}, \log \end{array}$ & $\begin{array}{c}\text { Forward Rate at } \\
25^{\circ} \mathrm{C}, \mathrm{mol} / \mathrm{m}^{2} / \mathrm{s}\end{array}$ & $\begin{array}{c}\text { Activation } \\
\text { Energy, } \mathrm{kJ} / \mathrm{mol}\end{array}$ \\
\hline Calcite $+\mathrm{H}^{+}=\mathrm{HCO}_{3}{ }^{-}+\mathrm{Ca}^{2+}$ & 1.847 & $1.5 \mathrm{E}-6$ & 23.5 \\
Cerussite $+\mathrm{H}^{+}=\mathrm{HCO}_{3}{ }^{-}+\mathrm{Pb}^{2+}$ & -2.963 & $1.5 \mathrm{E}-6$ & 23.5 \\
Dolomite $(\mathrm{dis})+2 \mathrm{H}^{+}=2 \mathrm{HCO}_{3}{ }^{-}+\mathrm{Ca}^{2+}+\mathrm{Mg}^{2+}$ & 4.299 & $2.9 \mathrm{E}-8$ & 52.2 \\
Illite $(\mathrm{Mg})+8.4 \mathrm{H}^{+}+1.6 \mathrm{H}_{2} \mathrm{O}=2.35 \mathrm{Al}^{3+}+0.85 \mathrm{~K}^{+}$ & 10.026 & $1.0 \mathrm{E}-14$ & 58.62 \\
$+0.25 \mathrm{Mg}^{2+}+3.4 \mathrm{H}_{4} \mathrm{SiO}_{4}$ & 6.472 & $1.0 \mathrm{E}-13$ & 62.76 \\
Kaolinite $+6 \mathrm{H}^{+}=2 \mathrm{Al}^{3+}+2 \mathrm{H}_{4} \mathrm{SiO}_{4}+\mathrm{H}_{2} \mathrm{O}$ & -1.773 & $1.5 \mathrm{E}-6$ & 23.5 \\
Otavite $+\mathrm{H}^{+}=\mathrm{HCO}_{3}{ }^{-}+\mathrm{Cd}^{2+}$ & & & \\
\hline
\end{tabular}




\subsection{Surface Complexation Reactions}

Surface complexation reactions for calcite, illite, and kaolinite were included in the Edwards Aquifer model, based on data from the literature. These reactions were compiled in collaboration with LBNL.

\subsubsection{Sorption on Calcite}

\section{Arsenate and Arsenite}

Adsorption and desorption of arsenate $(\mathrm{As}(\mathrm{V}))$ and arsenite $(\mathrm{As}(\mathrm{III}))$ were investigated in a series of batch experiments in calcite-equilibrated solutions (Sø et al. 2008). The researchers found that arsenate sorbs and desorbs readily on carbonate, whereas arsenite does not. The sorption of arsenate on calcite was modeled using a surface complexation model (SCM) consisting of strong and weak sites (Table 3.3).

\section{Phosphate}

Adsorption of phosphate onto calcite was studied in a series of batch experiments (Sø et al. 2011). Results showed strong sorption of phosphate onto calcite, with fast sorption and desorption. The sorption of phosphate on calcite was modeled using a surface complexation model consisting of strong and weak sites (Table 3.3). Phosphate is included because it will compete with arsenate for sorption sites on calcite.

Table 3.3. Surface protonation and complexation reactions of anions on calcite.

\begin{tabular}{|c|c|c|c|c|c|c|}
\hline Reactions & Log $k_{\text {int }}$ & $\begin{array}{c}\text { Site } \\
\text { Density } \\
\left(\mathrm{mol} / \mathrm{m}^{2}\right) \\
\end{array}$ & $\begin{array}{c}\text { Surface } \\
\text { Area } \\
\left(\mathrm{m}^{2} / \mathrm{g}\right)\end{array}$ & $\begin{array}{c}\text { Amount } \\
\text { of Solid } \\
(\mathrm{g} / \mathrm{kg} \\
\text { water }) \\
\end{array}$ & $\begin{array}{l}\text { Type of } \\
\text { SCM }\end{array}$ & Reference \\
\hline cal_ $\mathrm{CO}_{3} \mathrm{H}^{0}=$ cal_ $\mathrm{CO}_{3}^{-}+\mathrm{H}^{+}$ & -5.1 & $8.22 \mathrm{E}-6$ & 0.22 & 200 & $\operatorname{DLM}^{(\mathrm{a})}$ & \multirow{10}{*}{$\begin{array}{l}\text { (Sø et al. } \\
2008)\end{array}$} \\
\hline cal_CO $\mathrm{CO}_{3} \mathrm{H}^{0}+\mathrm{Ca}^{2+}=$ cal_ $\mathrm{CO}_{3} \mathrm{Ca}^{+}+\mathrm{H}^{+}$ & -1.7 & $8.22 \mathrm{E}-6$ & 0.22 & 200 & DLM & \\
\hline cal_CaCO${ }_{3}^{-}+\mathrm{H}_{2} \mathrm{O}=$ cal_ $\mathrm{CaOH}^{2+}+\mathrm{CO}_{3}^{2-}$ & -5.25 & $7.99 \mathrm{E}-6$ & 0.22 & 200 & DLM & \\
\hline cal_ $\mathrm{CaCO}_{3}^{-}+\mathrm{HCO}_{3}^{-}=$cal_CaHCO${ }_{3}^{0}+\mathrm{CO}_{3}^{2-}$ & -3.929 & $7.99 \mathrm{E}-6$ & 0.22 & 200 & DLM & \\
\hline $\mathrm{cal}_{\mathrm{CO}_{3}^{-2}} \mathrm{CaCO}_{3}^{-}+\mathrm{H}_{2} \mathrm{AsO}_{4}^{-}=\mathrm{cal} \_\mathrm{CaHAs} \mathrm{O}_{4}^{-}+\mathrm{H}^{+}+$ & -8.97 & $7.99 \mathrm{E}-6$ & 0.22 & 200 & DLM & \\
\hline $\begin{array}{l}\mathrm{cal} \mathrm{CaCO}_{3}{ }^{-}+\mathrm{CaHAsO}_{4}{ }^{0}=\mathrm{cal} \_\mathrm{CaAsO} 4 \mathrm{Ca} 0+\mathrm{H}^{+} \\
+\mathrm{CO}_{3}{ }^{2-}\end{array}$ & -9.81 & $7.99 \mathrm{E}-6$ & 0.22 & 200 & DLM & \\
\hline cal_s $\mathrm{saCO}_{3}^{-}+\mathrm{H}_{2} \mathrm{O}=\mathrm{cal} \_\mathrm{sCaOH}{ }_{2}^{+}+\mathrm{CO}_{3}^{2-}$ & -5.25 & $2.3 \mathrm{E}-7$ & 0.22 & 200 & DLM & \\
\hline cal_sCaCO${ }_{3}^{-}+\mathrm{HCO}_{3}^{-}=$cal_sCaHCO${ }_{3}^{0}+\mathrm{CO}_{3}^{2-}$ & -3.929 & $2.3 \mathrm{E}-7$ & 0.22 & 200 & DLM & \\
\hline 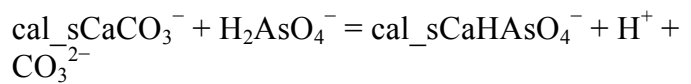 & -7.98 & $2.3 \mathrm{E}-7$ & 0.22 & 200 & DLM & \\
\hline $\begin{array}{l}\mathrm{cal} \mathrm{sCaCO}_{3}^{-}+\mathrm{CaHAsO}_{4}{ }^{0}=\mathrm{cal}_{-} \mathrm{SCaAsO}_{4} \mathrm{Ca}^{0}+ \\
\mathrm{H}^{+}+\mathrm{CO}_{3}{ }^{2-}\end{array}$ & -7.22 & $2.3 \mathrm{E}-7$ & 0.22 & 200 & DLM & \\
\hline cal_CaCO${ }_{3}^{-}+\mathrm{HPO}_{4}{ }^{2-}=$ cal_CaHPO${ }_{4}^{-}+\mathrm{CO}_{3}{ }^{2-}$ & -2.00 & $7.31 \mathrm{E}-6$ & 0.22 & 100 & DLM & \multirow{4}{*}{$\begin{array}{l}\text { (Sø et al. } \\
2011)\end{array}$} \\
\hline cal_ $\mathrm{CaCO}_{3}{ }^{-}+\mathrm{CaPO}_{4}^{-}=\mathrm{cal}{ }_{-} \mathrm{CaPO}_{4} \mathrm{Ca}^{0}+\mathrm{CO}_{3}{ }^{2-}$ & -0.72 & $7.31 \mathrm{E}-6$ & 0.22 & 100 & DLM & \\
\hline cal_sCaCO ${ }_{3}^{-}+\mathrm{HPO}_{4}{ }^{2-}=\mathrm{cal}{ }_{-} \mathrm{CaHPO}_{4}^{-}+\mathrm{CO}_{3}{ }^{2-}$ & 0.17 & $9.1 \mathrm{E}-7$ & 0.22 & 100 & DLM & \\
\hline cal_sCaCO${ }_{3}^{-}+\mathrm{CaPO}_{4}^{-}=\mathrm{cal} \_\mathrm{sCaPO}_{4} \mathrm{Ca}^{0}+\mathrm{CO}_{3}{ }^{2-}$ & 2.30 & $9.1 \mathrm{E}-7$ & 0.22 & 100 & DLM & \\
\hline
\end{tabular}

(a) $\mathrm{DLM}=$ double layer model 


\subsubsection{Sorption on Illite}

\section{Surface Protonation}

Clay minerals such as illite, kaolinite, and smectite usually possess two types of surface sites: 1) a permanent, negatively charged site whose charges are structural (also called basal face sites in some publications) and 2) variably charged sites that usually reside at the edge of minerals (also called edge sites in some publications). The acid-base properties of clay minerals are usually described by a protonation reaction on the basal face sites (represented as ill_bH) and two protonation reactions on the edge sites (ill_eOH${ }_{2}^{+}$and ill_eO ${ }^{-}$). Recent experiments provide the surface protonation reaction on illite while reporting the adsorption of several trace metals on illite (Table 3.4) (Gu and Evans 2007).

\section{Cadmium and Lead}

Sorption data for cadmium was fitted with one monodentate surface reaction on edge sites (ill_eOCd ${ }^{+}$ in Table 3.2) and two sorption reactions on basal surface sites ((ill_b ${ }_{2} \mathrm{Cd}^{+}$and ill_bHCd $\left.{ }^{2+}\right)$, with the surface reaction on edge sites playing a minimal role in fitting the data and therefore ignored ( $\mathrm{Gu}$ and Evans 2007). For compatibility reasons, the same author's Constant Capacitance Model (CCM) for sorption of lead on illite is adopted (Table 3.4) (Gu and Evans 2007).

Table 3.4. Surface protonation and complexation reactions of cations on illite.

\begin{tabular}{|c|c|c|c|c|c|c|}
\hline Reactions & $\begin{array}{r}\log \\
k_{\text {int }} \\
\end{array}$ & $\begin{array}{c}\begin{array}{c}\text { Site } \\
\text { Density } \\
\left(\mathrm{mol} / \mathrm{m}^{2}\right)\end{array} \\
\end{array}$ & $\begin{array}{c}\text { Surface } \\
\text { Area } \\
\left(\mathrm{m}^{2} / \mathrm{g}\right) \\
\end{array}$ & $\begin{array}{c}\text { Amount } \\
\text { of Solid } \\
(\mathrm{g} / \mathrm{kg} \\
\text { water }) \\
\end{array}$ & $\begin{array}{c}\text { Type of SCM } \\
\text { with } \\
\text { Capacitance } \\
\kappa \\
\end{array}$ & Reference \\
\hline ill_eOH${ }_{2}^{+}=$ill_eOH $+\mathrm{H}^{+}$ & -8.02 & $2.27 \mathrm{E}-6$ & 66.8 & 0.03 & $\begin{array}{l}\mathrm{CCM}, \\
\kappa=2.0 \mathrm{~F} / \mathrm{m}^{2}\end{array}$ & \multirow{3}{*}{$\begin{array}{l}\text { (Gu and } \\
\text { Evans 2007) }\end{array}$} \\
\hline ill_eO- $+\mathrm{H}^{+}=$ill_eOH & 8.93 & $2.27 \mathrm{E}-6$ & 66.8 & 0.03 & $\begin{array}{l}\mathrm{CCM}, \\
\kappa=2.0 \mathrm{~F} / \mathrm{m}^{2}\end{array}$ & \\
\hline ill_bNa $+\mathrm{H}^{+}=$ill_bH $+\mathrm{Na}$ & 1.58 & $1.3 \mathrm{E}-6$ & 66.8 & 0.03 & $\begin{array}{l}\mathrm{CCM}, \\
\kappa=2.0 \mathrm{~F} / \mathrm{m}^{2}\end{array}$ & \\
\hline ill_eOCd ${ }^{+}+\mathrm{H}^{+}=$ill_eOH $+\mathrm{Cd}^{2+}$ & 3.62 & $2.27 \mathrm{E}-6$ & 66.8 & 0.03 & $\begin{array}{l}\mathrm{CCM}, \\
\kappa=2.0 \mathrm{~F} / \mathrm{m}^{2}\end{array}$ & \multirow{4}{*}{$\begin{array}{l}\text { (Gu and } \\
\text { Evans 2007) }\end{array}$} \\
\hline$\left(\text { ill } \_b\right)_{2} \mathrm{Cd}+2 \mathrm{H}^{+}=2$ ill_bH $+\mathrm{Cd}^{2+}$ & -0.63 & $1.3 \mathrm{E}-6$ & 66.8 & 0.03 & $\begin{array}{l}\mathrm{CCM}, \\
\kappa=2.0 \mathrm{~F} / \mathrm{m}^{2}\end{array}$ & \\
\hline ill_bCdOH $+2 \mathrm{H}^{+}=$ill_bH $+\mathrm{Cd}^{2+}+\mathrm{H}_{2} \mathrm{O}$ & 6.49 & $1.3 \mathrm{E}-6$ & 66.8 & 0.03 & $\begin{array}{l}\mathrm{CCM} \\
\kappa=2.0 \mathrm{~F} / \mathrm{m}^{2}\end{array}$ & \\
\hline ill_eOPb ${ }^{+}+\mathrm{H}^{+}=$ill_eOH $+\mathrm{Pb}^{2+}$ & 0.70 & $2.27 \mathrm{E}-6$ & 66.8 & 0.03 & $\begin{array}{l}\mathrm{CCM}, \\
\kappa=2.0 \mathrm{~F} / \mathrm{m}^{2}\end{array}$ & \\
\hline$(\text { ill_b })_{2} \mathrm{~Pb}+2 \mathrm{H}^{+}=2$ ill_bH $+\mathrm{Pb}^{2+}$ & -1.37 & $1.3 \mathrm{E}-6$ & 66.8 & 0.03 & $\begin{array}{l}\mathrm{CCM}, \\
\kappa=2.0 \mathrm{~F} / \mathrm{m}^{2}\end{array}$ & \multirow[t]{2}{*}{$\begin{array}{l}\text { (Gu and } \\
\text { Evans 2007) }\end{array}$} \\
\hline ill_bPbOH $+2 \mathrm{H}^{+}=$ill_bH $+\mathrm{Pb}^{2+}+\mathrm{H}_{2} \mathrm{O}$ & 3.65 & $1.3 \mathrm{E}-6$ & 66.8 & 0.03 & $\begin{array}{l}\mathrm{CCM}, \\
\kappa=2.0 \mathrm{~F} / \mathrm{m}^{2}\end{array}$ & \\
\hline
\end{tabular}




\section{Arsenic}

Sorption of $\mathrm{As}(\mathrm{III})$ and $\mathrm{As}(\mathrm{V})$ on illite has been modeled using monodentate surface species (Table 3.5) (Goldberg 2002).

Table 3.5. Surface protonation and complexation of oxyanions on illite.

\begin{tabular}{|c|c|c|c|c|c|c|}
\hline Reactions & Log $k_{\text {int }}$ & $\begin{array}{l}\text { Site Density } \\
\left(\mathrm{mol} / \mathrm{m}^{2}\right)\end{array}$ & $\begin{array}{c}\text { Surface } \\
\text { Area } \\
\left(\mathrm{m}^{2} / \mathrm{g}\right)\end{array}$ & $\begin{array}{c}\text { Amount of } \\
\text { Solid } \\
\text { (g/kg } \\
\text { water) }\end{array}$ & $\begin{array}{c}\text { Type of SCM } \\
\text { with } \\
\text { Capacitance } \\
\kappa\end{array}$ & Reference \\
\hline ill_eOH${ }_{2}^{+}=$ill_eOH $+\mathrm{H}^{+}$ & -7.38 & $3.83 \mathrm{E}-6$ & 22.6 & 40 & $\begin{array}{l}\mathrm{CCM}, \\
\kappa=1.06 \mathrm{~F} / \mathrm{m}^{2}\end{array}$ & (Goldberg \\
\hline ill_eO ${ }^{-}+\mathrm{H}^{+}=$ill_eOH & 9.09 & $3.83 \mathrm{E}-6$ & 22.6 & 40 & $\begin{array}{l}\mathrm{CCM}, \\
\kappa=1.06 \mathrm{~F} / \mathrm{m}^{2}\end{array}$ & 2002) \\
\hline $\begin{array}{l}\text { ill_e } \mathrm{eH}_{2} \mathrm{AsO}_{3}+\mathrm{H}_{2} \mathrm{O}= \\
\text { ill_eOH }+\mathrm{H}_{3} \mathrm{AsO}_{3}\end{array}$ & -2.12 & $3.83 \mathrm{E}-6$ & 22.6 & 40 & $\begin{array}{l}\mathrm{CCM}, \\
\kappa=1.06 \mathrm{~F} / \mathrm{m}^{2}\end{array}$ & (Goldberg \\
\hline $\begin{array}{l}\text { ill_eHAsO }{ }_{3}^{-}+\mathrm{H}_{2} \mathrm{O}+\mathrm{H}^{+}= \\
\text {ill_eOH }+\mathrm{H}_{3} \mathrm{AsO}_{3}\end{array}$ & 5.66 & $3.83 \mathrm{E}-6$ & 22.6 & 40 & $\begin{array}{l}\mathrm{CCM}, \\
\kappa=1.06 \mathrm{~F} / \mathrm{m}^{2}\end{array}$ & 2002) \\
\hline $\begin{array}{l}\text { ill_eAsO }{ }_{4}{ }^{2-}+\mathrm{H}_{2} \mathrm{O}+2 \mathrm{H}^{+}= \\
\text {ill_eOH }+\mathrm{H}_{3} \mathrm{AsO}_{4}\end{array}$ & 5.21 & $3.83 \mathrm{E}-6$ & 22.6 & 40 & $\begin{array}{l}\mathrm{CCM}, \\
\kappa=1.06 \mathrm{~F} / \mathrm{m}^{2}\end{array}$ & $\begin{array}{l}\text { (Goldberg } \\
\text { 2002) }\end{array}$ \\
\hline
\end{tabular}

\subsubsection{Sorption on Kaolinite}

\section{Surface Protonation}

Similar to the surface protonation on illite, the acid-base properties of kaolinite are also described by a protonation reaction on the basal face sites (represented as kao_bH) and two protonation reactions on the edge sites $\left(\mathrm{kao}_{-} \mathrm{eOH}_{2}{ }^{+}\right.$and $\mathrm{kao}_{-} \mathrm{eO}^{-}$). The protonation reaction on the basal face sites is usually described by a cation exchange reaction with the cations of the supporting electrolyte in the potentiometric titrations. For example, recent experiments used $\mathrm{NaNO}_{3}$ as a supporting electrolyte and therefore used exchange reactions between $\mathrm{H}$ and $\mathrm{Na}$ (Table 3.6) (Gu and Evans 2008).

\section{Cadmium}

For the adsorption of $\mathrm{Cd}$ on kaolinite, a monodentate surface species $\left(\mathrm{kao}_{-} \mathrm{eOCd}{ }^{+}\right)$for edge sites and a bidentate surface species for basal sites (kao_b) ${ }_{2} \mathrm{Cd}$ are assumed (Gu and Evans 2008).

\section{Lead}

For the adsorption of $\mathrm{Pb}$ on kaolinite, a monodentate surface species $\left(\mathrm{kao}_{-} \mathrm{eOPb}{ }^{+}\right.$) for edge sites and a bidentate surface species for basal sites (kao_b) ${ }_{2} \mathrm{~Pb}$ are assumed (Gu and Evans 2008). 
Table 3.6. Surface protonation and complexation reactions of cations on kaolinite.

\begin{tabular}{|c|c|c|c|c|c|c|}
\hline Reactions & $\begin{array}{r}\log \\
k_{\text {int }}\end{array}$ & $\begin{array}{c}\text { Site } \\
\text { Density } \\
\left(\mathrm{mol} / \mathrm{m}^{2}\right) \\
\end{array}$ & $\begin{array}{c}\text { Surface } \\
\text { Area } \\
\left(\mathrm{m}^{2} / \mathrm{g}\right)\end{array}$ & $\begin{array}{c}\text { Amount } \\
\text { of Solid } \\
(\mathrm{g} / \mathrm{kg} \\
\text { water }) \\
\end{array}$ & $\begin{array}{c}\text { Type of SCM } \\
\text { with } \\
\text { Capacitance } \\
\kappa \\
\end{array}$ & Reference \\
\hline kao_eOH${ }_{2}^{+}=$kao_eOH $+\mathrm{H}^{+}$ & -4.63 & $2.24 \mathrm{E}-6$ & 22.42 & 7.8 & $\begin{array}{l}\mathrm{CCM} \\
\kappa=1.2 \mathrm{~F} / \mathrm{m}^{2}\end{array}$ & \multirow{3}{*}{$\begin{array}{l}\text { (Gu and } \\
\text { Evans 2008) }\end{array}$} \\
\hline kao_eO ${ }^{-}+\mathrm{H}^{+}=$kao_eOH & 7.54 & $2.24 \mathrm{E}-6$ & 22.42 & 7.8 & $\begin{array}{l}\mathrm{CCM}, \\
\kappa=1.2 \mathrm{~F} / \mathrm{m}^{2}\end{array}$ & \\
\hline kao_bNa ${ }^{+}+\mathrm{H}^{+}=\mathrm{kao} \_\mathrm{bH}+\mathrm{Na}^{+}$ & 2.02 & $3.57 \mathrm{E}-7$ & 22.42 & 7.8 & $\begin{array}{l}\mathrm{CCM} \\
\kappa=1.2 \mathrm{~F} / \mathrm{m}^{2}\end{array}$ & \\
\hline kao_eOCd ${ }^{+}+\mathrm{H}^{+}=$kao_eOH $+\mathrm{Cd}^{+2}$ & 3.23 & $2.24 \mathrm{E}-6$ & 22.42 & 7.8 & $\begin{array}{l}\mathrm{CCM} \\
\kappa=1.2 \mathrm{~F} / \mathrm{m}^{2}\end{array}$ & \multirow{2}{*}{$\begin{array}{l}\text { (Gu and } \\
\text { Evans 2008) }\end{array}$} \\
\hline$\left(\mathrm{kao} \_\mathrm{b}\right)_{2} \mathrm{Cd}+2 \mathrm{H}^{+}=2 \mathrm{kao} \_\mathrm{bH}+\mathrm{Cd}^{2+}$ & -1.22 & $3.57 \mathrm{E}-7$ & 22.42 & 7.8 & $\begin{array}{l}\mathrm{CCM} \\
\kappa=1.2 \mathrm{~F} / \mathrm{m}^{2}\end{array}$ & \\
\hline kao_eOPb ${ }^{+}+\mathrm{H}^{+}=\mathrm{kao} \_\mathrm{eOH}+\mathrm{Pb}^{2+}$ & 0.64 & $2.24 \mathrm{E}-6$ & 22.42 & 7.8 & $\begin{array}{l}\mathrm{CCM} \\
\kappa=1.2 \mathrm{~F} / \mathrm{m}^{2}\end{array}$ & \multirow{2}{*}{$\begin{array}{l}\text { (Gu and } \\
\text { Evans 2008) }\end{array}$} \\
\hline$\left(\mathrm{kao} \_b\right)_{2} \mathrm{~Pb}+2 \mathrm{H}^{+}=2 \mathrm{kao} \_\mathrm{bH}+\mathrm{Pb}^{2+}$ & -2.36 & $3.57 \mathrm{E}-7$ & 22.42 & 7.8 & $\begin{array}{l}\mathrm{CCM} \\
\kappa=1.2 \mathrm{~F} / \mathrm{m}^{2}\end{array}$ & \\
\hline
\end{tabular}

\section{Arsenic}

Sorption of $\mathrm{As}(\mathrm{III})$ and $\mathrm{As}(\mathrm{V})$ on kaolinite has been modeled using monodentate surface species (Table 3.7) (Goldberg 2002).

Table 3.7. Surface protonation and complexation reactions of anions on kaolinite.

\begin{tabular}{|c|c|c|c|c|c|c|}
\hline Reactions & $\begin{array}{r}\log \\
k_{\text {int }}\end{array}$ & $\begin{array}{c}\begin{array}{c}\text { Site } \\
\text { Density } \\
\left(\mathrm{mol} / \mathrm{m}^{2}\right)\end{array} \\
\end{array}$ & $\begin{array}{c}\text { Surface } \\
\text { Area } \\
\left(\mathrm{m}^{2} / \mathrm{g}\right)\end{array}$ & $\begin{array}{c}\text { Amount } \\
\text { of Solid } \\
(\mathrm{g} / \mathrm{kg} \\
\text { water }) \\
\end{array}$ & $\begin{array}{c}\text { Type of SCM } \\
\text { with } \\
\text { Capacitance } \\
\kappa \\
\end{array}$ & Reference \\
\hline kao_eOH${ }^{+}=$kao_eOH $+\mathrm{H}^{+}$ & -7.38 & $3.83 \mathrm{E}-6$ & 21.6 & 40 & $\begin{array}{l}\mathrm{CCM}, \\
\kappa=1.06 \mathrm{~F} / \mathrm{m}^{2}\end{array}$ & (Goldberg \\
\hline kao_eO ${ }^{-}+\mathrm{H}^{+}=$kao_eOH & 9.09 & $3.83 \mathrm{E}-6$ & 21.6 & 40 & $\begin{array}{l}\mathrm{CCM} \\
\kappa=1.06 \mathrm{~F} / \mathrm{m}^{2}\end{array}$ & 2002) \\
\hline $\begin{array}{l}\mathrm{kao} \_e H A s O_{3}{ }^{-}+\mathrm{H}_{2} \mathrm{O}+\mathrm{H}^{+}=\text {kao_eOH }+ \\
\mathrm{H}_{3} \mathrm{AsO}_{3}\end{array}$ & 5.43 & $3.83 \mathrm{E}-6$ & 21.6 & 40 & $\begin{array}{l}\mathrm{CCM} \\
\kappa=1.06 \mathrm{~F} / \mathrm{m}^{2}\end{array}$ & $\begin{array}{l}\text { (Goldberg } \\
\text { 2002) }\end{array}$ \\
\hline $\begin{array}{l}\mathrm{kao}_{\mathrm{k}} \mathrm{eAsO}_{4}{ }^{2-}+\mathrm{H}_{2} \mathrm{O}+2 \mathrm{H}^{+}=\mathrm{kao} \_\mathrm{eOH}+ \\
\mathrm{H}_{3} \mathrm{AsO}_{4}\end{array}$ & 4.69 & $3.83 \mathrm{E}-6$ & 21.6 & 40 & $\begin{array}{l}\mathrm{CCM} \\
\kappa=1.06 \mathrm{~F} / \mathrm{m}^{2}\end{array}$ & $\begin{array}{l}\text { (Goldberg } \\
\text { 2002) }\end{array}$ \\
\hline
\end{tabular}

\subsection{Boundary Conditions}

Groundwater flows into the domain at the north boundary $(\mathrm{Y}=8 \mathrm{~km})$ at a rate that varies with permeability. A horizontal pressure gradient of $8.5 \times 10^{-6} \mathrm{MPa} / \mathrm{m}$ in the $\mathrm{Y}$-direction is based on observed heads (Hutchison and Hill 2011). The south boundary $(\mathrm{Y}=0)$ is an outflow boundary. The east $(\mathrm{X}=5 \mathrm{~km})$ and west $(\mathrm{X}=0)$ boundaries are no flow. The bottom boundary is no flow, except for the $\mathrm{CO}_{2}$ and brine leaks at $\mathrm{X}=2.5 \mathrm{~km}, \mathrm{Y}=7 \mathrm{~km}$. The top boundary is the water table, which is a no-flow 
boundary for the liquid phase, but is a constant pressure boundary of $0.101325 \mathrm{MPa}$ (atmospheric pressure) for the gas phase.

\subsection{Initial Conditions}

Initial conditions for $\mathrm{pH}, \mathrm{H}_{2} \mathrm{AsO}_{4}{ }^{-}, \mathrm{Cd}^{2+}$ and $\mathrm{Pb}^{2+}$ were taken from Table 2.1. Initial conditions for other aqueous species were based on the average aqueous concentrations for the 90 groundwater samples from the shallow urban unconfined portion of the Edwards Aquifer (Musgrove et al. 2010). These values are shown in Table 3.8 .

Table 3.8. Initial aqueous species concentrations.

\begin{tabular}{lcc}
\hline \multicolumn{1}{c}{ Species } & Concentration & Unit \\
\hline $\mathrm{HCO}_{3}{ }^{-}$ & $2.86 \mathrm{E}^{-} 04$ & Aqueous Mass Fraction \\
$\mathrm{AlO}_{2}{ }^{-}$ & $1.96 \mathrm{E}^{-} 07$ & $\mathrm{~mol} /$ liter \\
$\mathrm{H}_{2} \mathrm{AsO}_{4}^{-}$ & $4.19 \mathrm{E}^{-} 09$ & $\mathrm{~mol} /$ liter \\
$\mathrm{Ca}^{2+}$ & $2.48 \mathrm{E}^{-} 03$ & $\mathrm{~mol} /$ liter \\
$\mathrm{Cd}^{2+}$ & $3.56 \mathrm{E}^{-} 13$ & $\mathrm{~mol} /$ liter \\
$\mathrm{Cl}^{-}$ & $3.31 \mathrm{E}^{-} 04$ & $\mathrm{~mol} /$ liter \\
$\mathrm{F}^{-}$ & $5.79 \mathrm{E}^{-} 06$ & $\mathrm{~mol} /$ liter \\
$\mathrm{Fe}^{2+}$ & $1.05 \mathrm{E}^{-} 07$ & $\mathrm{~mol} /$ liter \\
$\mathrm{pH}^{\mathrm{K}^{+}}$ & 6.86 & \\
$\mathrm{Mg}^{2+}$ & $1.64 \mathrm{E}^{-} 05$ & $\mathrm{~mol} /$ liter \\
$\mathrm{Na}^{+}$ & $3.17 \mathrm{E}^{-} 04$ & $\mathrm{~mol} /$ liter \\
$\mathrm{HPO}_{4}{ }^{2-}$ & $3.34 \mathrm{E}^{-} 04$ & $\mathrm{~mol} /$ liter \\
$\mathrm{Pb}^{2+}$ & $1.32 \mathrm{E}^{-} 06$ & $\mathrm{~mol} /$ liter \\
$\mathrm{SO}_{4}{ }^{2-}$ & $3.09 \mathrm{E}^{-} 10$ & $\mathrm{~mol} /$ liter \\
$\mathrm{H}_{4} \mathrm{SiO}_{4}$ & $3.47 \mathrm{E}^{-} 04$ & $\mathrm{~mol} /$ liter \\
\hline & $3.90 \mathrm{E}^{-} 04$ & $\mathrm{~mol} /$ liter \\
\hline
\end{tabular}




\subsection{Well Leak Reduced-Order Model}

The Wellbore Leakage ROM was used to generate the $\mathrm{CO}_{2}$ and brine source terms for the STOMP groundwater flow and reactive transport simulations. The Wellbore Leakage ROM developed by LANL has several input parameters, whose ranges are listed in Table 4.1.

Table 4.1. Input parameters for Wellbore Leakage ROM.

\begin{tabular}{lcc}
\hline \multicolumn{1}{c}{ Variable } & Unit & Constant or Range \\
\hline Well depth & $\mathrm{m}$ & 1800 \\
Distance between injection and leaky well & $\mathrm{m}$ & 500 \\
Wellbore cement permeability & Log m & -14 to -8 \\
Maximum $\mathrm{CO}_{2}$ saturation in reservoir & & 0.35 to 1 \\
Maximum $\mathrm{CO}_{2}$ pressure in reservoir & $\mathrm{MPa}$ & 4.85 to 36 \\
\hline
\end{tabular}

The outputs of the Wellbore Leakage ROM are the $\mathrm{CO}_{2}$ leakage rate and the brine leakage rate, both in units of kilograms per second. The $\mathrm{CO}_{2}$ leak rate and the brine leak rate vs. time for median values of the Wellbore Leakage ROM input parameters are shown in Figure 4.1 and Figure 4.2, respectively.

The brine concentration of $\mathrm{NaCl}$ in $\mathrm{mol} / \mathrm{L}$ is treated as an uncertain variable, ranging from 0.5 to $5.4 \mathrm{~mol} / \mathrm{L}$. Arsenic, $\mathrm{Cd}$, and $\mathrm{Pb}$ concentration in the brine were assumed to be proportional to the $\mathrm{NaCl}$ concentration. The ratios were $3.16 \mathrm{E}-7,3.16 \mathrm{E}-8$ and $1.00 \mathrm{E}-5$ on a molar basis for $\mathrm{As}, \mathrm{Cd}$ and $\mathrm{Pb}$, respectively.

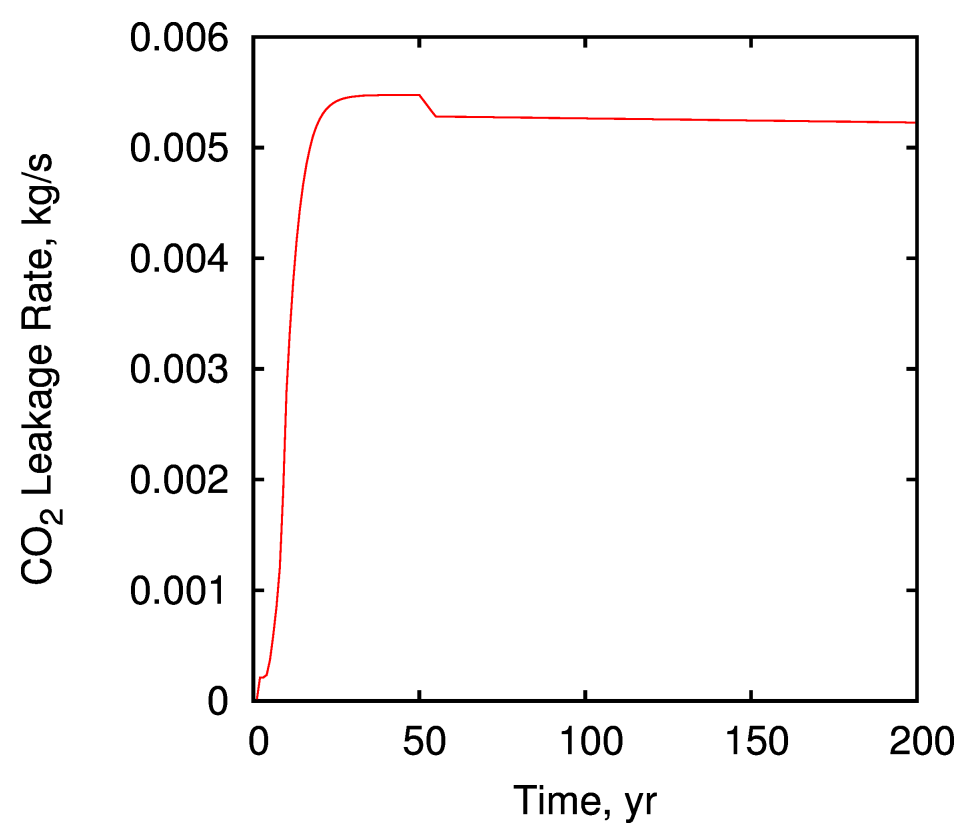

Figure 4.1. $\mathrm{CO}_{2}$ leakage rate for median values of the Wellbore Leakage ROM input parameters. 


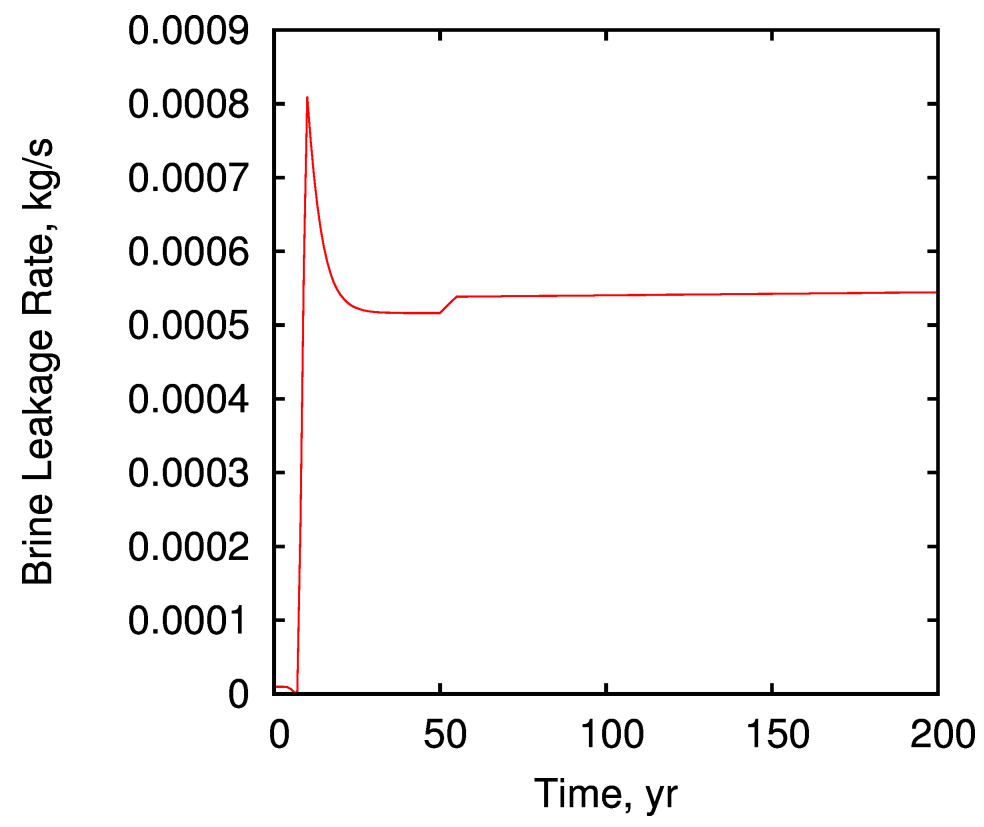

Figure 4.2. Brine leakage rate for median values of the Wellbore Leakage ROM input parameters. 


\subsection{Base-Case Model Results}

Using the model parameters described in Section 3.0, and the well leak rates described in Section 4.0, a base-case simulation was run to present average model results. As $\mathrm{CO}_{2}$ leaks into the aquifer, the $\mathrm{pH}$ is reduced from a background value of 6.86 to a minimum value of 4.96 (Figure 5.1). The decrease in $\mathrm{pH}$ drives the dissolution of calcite, increasing aqueous concentrations of calcium and carbonate. In addition, the brine leak increases the concentrations of sodium and chloride as well as the trace metals. As a result, both the $\mathrm{CO}_{2}$ and brine leaks contribute to an increase in TDS (Figure 5.2). Figure 5.3 shows the total aqueous arsenate concentration, Figure 5.4 the total aqueous Cd concentration, and Figure 5.5 the total aqueous $\mathrm{Pb}$ concentration. The $\mathrm{As}, \mathrm{Cd}$, and $\mathrm{Pb}$ are increased proportionally to the concentration of $\mathrm{NaCl}$ in the brine leak, and the lowered $\mathrm{pH}$ may cause an increase in $\mathrm{H}^{+}$on surface sites, displacing adsorbed trace metals.

The output variables to be used for risk analysis are the volume, length and width of plumes delineating $\mathrm{pH}$ below, and TDS, $\mathrm{As}, \mathrm{Cd}$, and $\mathrm{Pb}$ above defined thresholds. Threshold values were defined as either the "no-impact" limits (Last et al. 2013) or the drinking water MCLs, listed in Table 5.1.

Table 5.1. Threshold levels.

\begin{tabular}{lccc}
\hline \multicolumn{1}{c}{ Species } & No-Impact & MCL & Unit \\
\hline $\mathrm{pH}$ & $<6.6$ & $<6.5$ & \\
$\mathrm{TDS}$ & $>420$ & $>500$ & $\mathrm{mg} / \mathrm{L}$ \\
$\mathrm{As}$ & $>7.3 \mathrm{E}-9$ & $>1.33 \mathrm{E}-7$ & $\mathrm{~mol} / \mathrm{L}$ \\
$\mathrm{Cd}$ & $>3.6 \mathrm{E}-10$ & $>4.45 \mathrm{E}-8$ & $\mathrm{~mol} / \mathrm{L}$ \\
$\mathrm{Pb}$ & $>7.2 \mathrm{E}-10$ & $>7.24 \mathrm{E}-8$ & $\mathrm{~mol} / \mathrm{L}$ \\
\hline
\end{tabular}

Although the $\mathrm{CO}_{2}$ leak rate for this simulation was 10 times that of the brine leak rate, the TDS plume (Figure 5.6) is twice the volume of the $\mathrm{pH}$ plume (Figure 5.7), for either the no-impact or MCL limits. Dissolution of calcite buffers $\mathrm{pH}$ changes in the aquifer. The lead plume (Figure 5.10) is 6 times smaller than the TDS plume given MCL limits, but approximately $3 / 5$ the volume using no-impact limits.

Arsenic (Figure 5.8) and Cd (Figure 5.9) did not exceed the MCL limits for this base-case simulation, and are an order of magnitude smaller than the TDS plume. The $\mathrm{CO}_{2}$ flux to the atmosphere, shown in Figure 5.11, is highly correlated with the $\mathrm{CO}_{2}$ leak rate from the wellbore, shown previously in Figure 4.1. At 200 years, the $\mathrm{CO}_{2}$ flux to the atmosphere is $83 \%$ of the $\mathrm{CO}_{2}$ leak rate into the aquifer. 


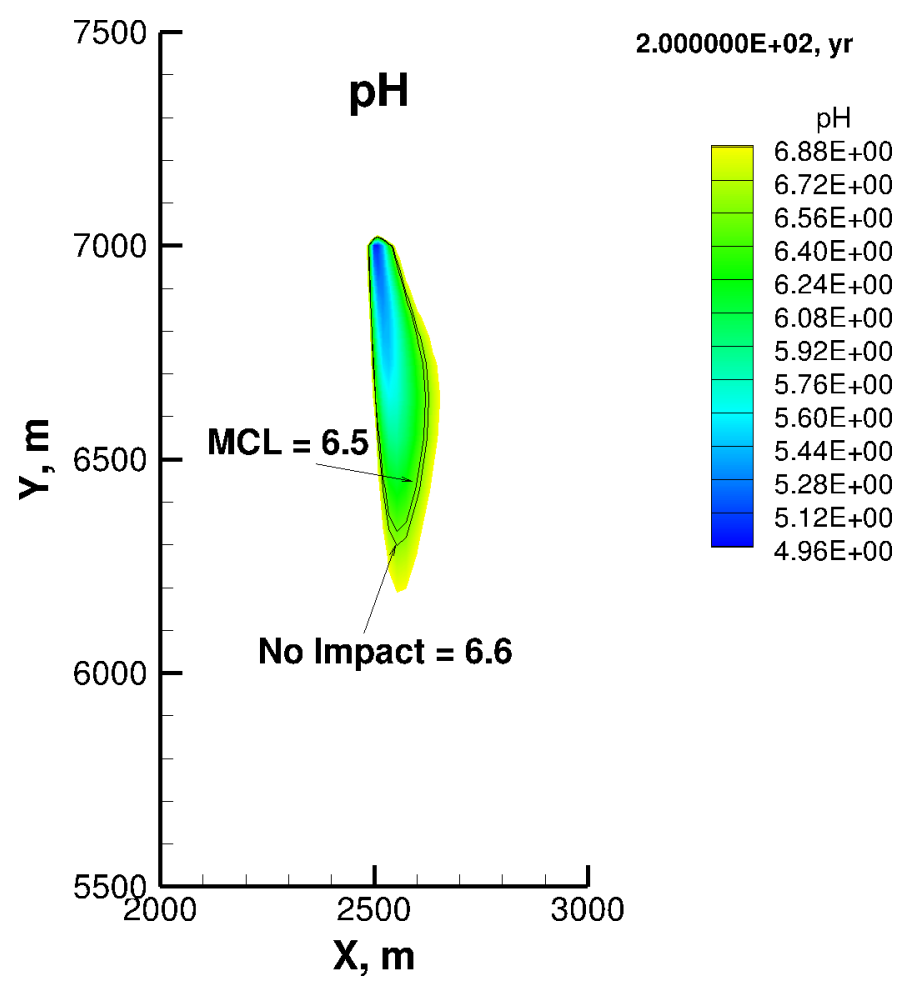

Figure 5.1. pH after 200 years of well leakage.

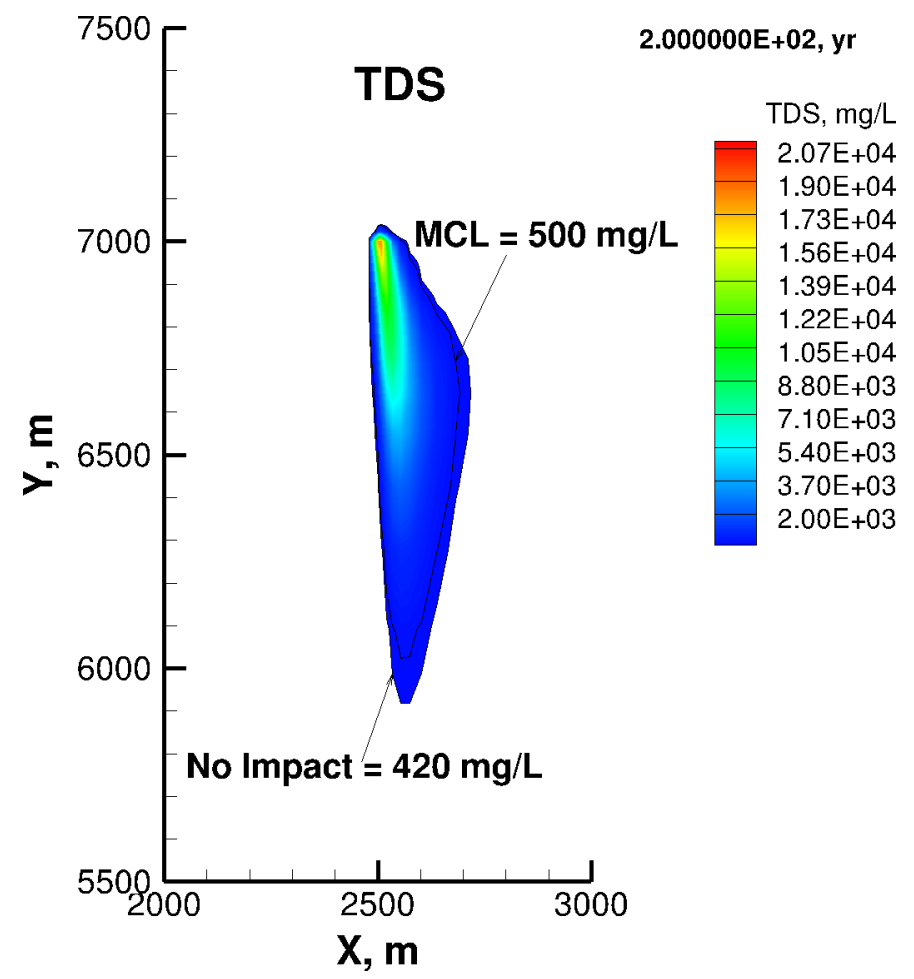

Figure 5.2. TDS after 200 years of well leakage. 


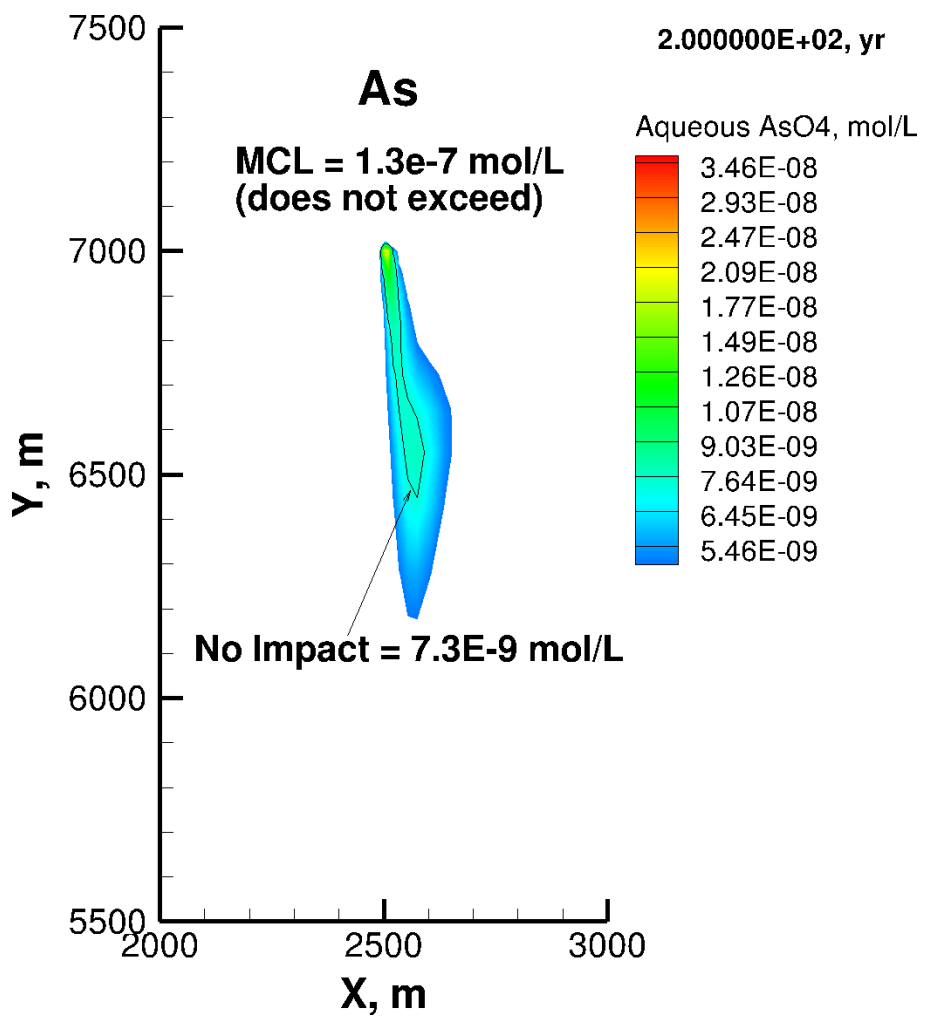

Figure 5.3. Total aqueous arsenate after 200 years of well leakage.

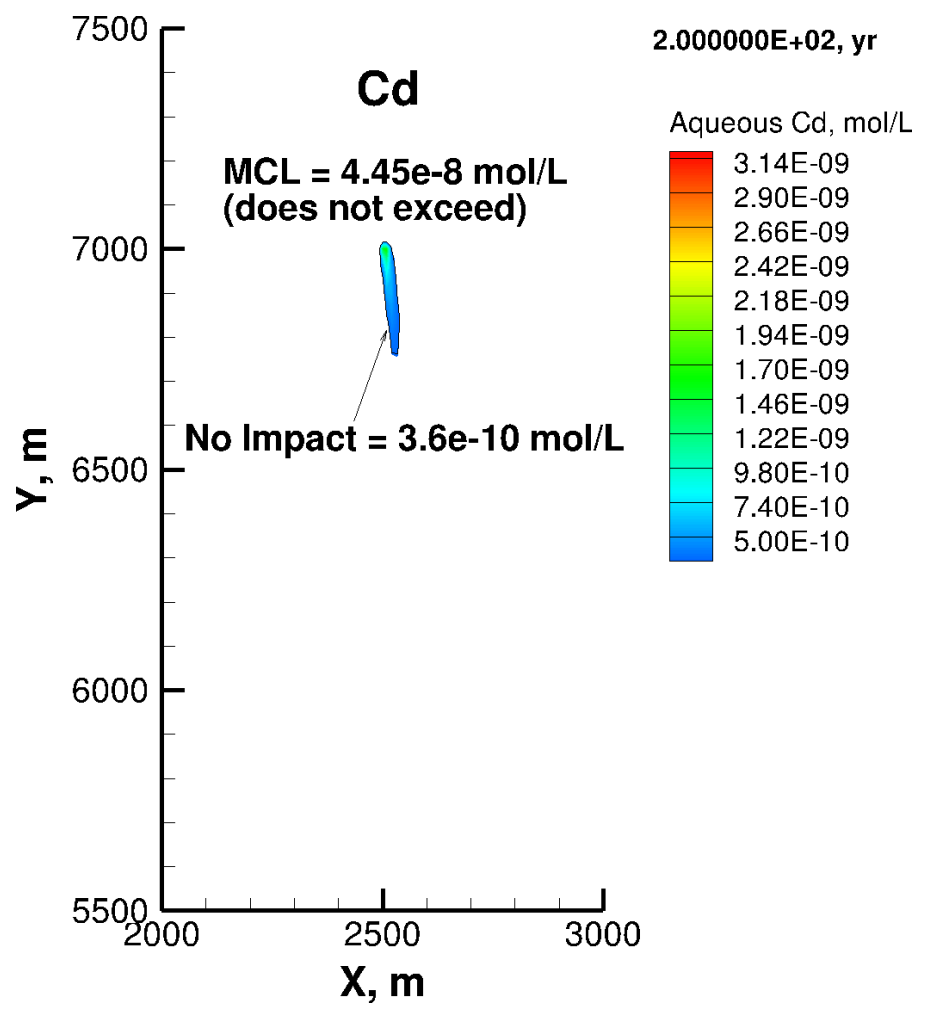

Figure 5.4. Total cadmium concentration after 200 years of well leakage. 


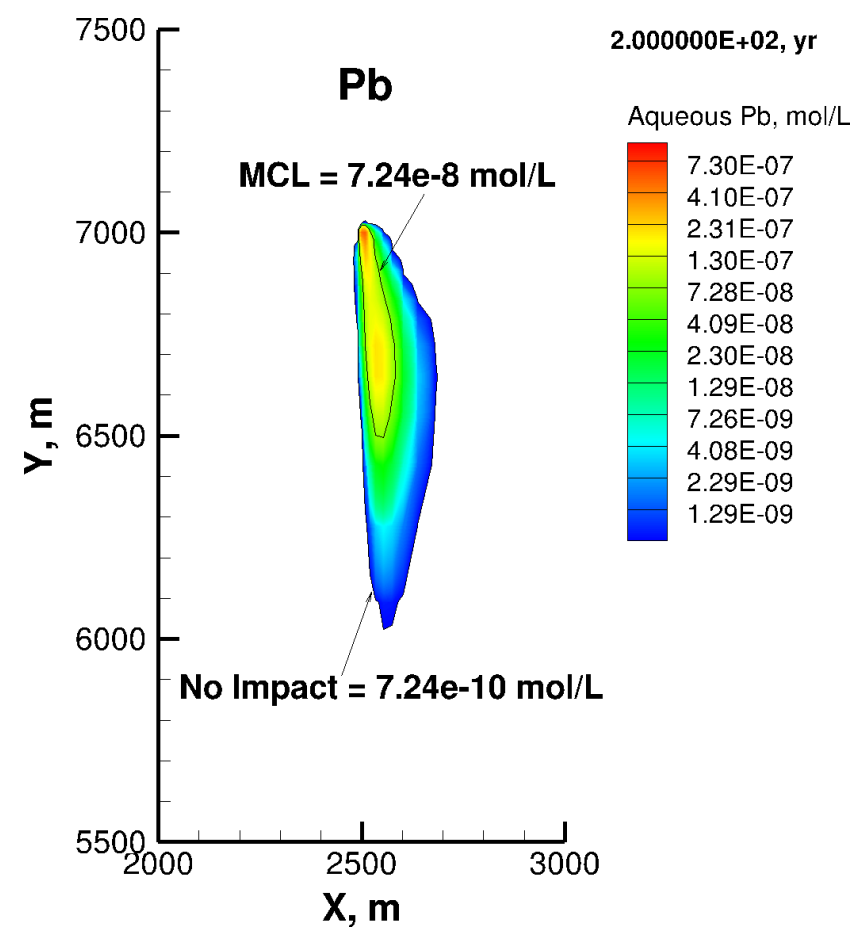

Figure 5.5. Total lead concentration after 200 years of well leakage.
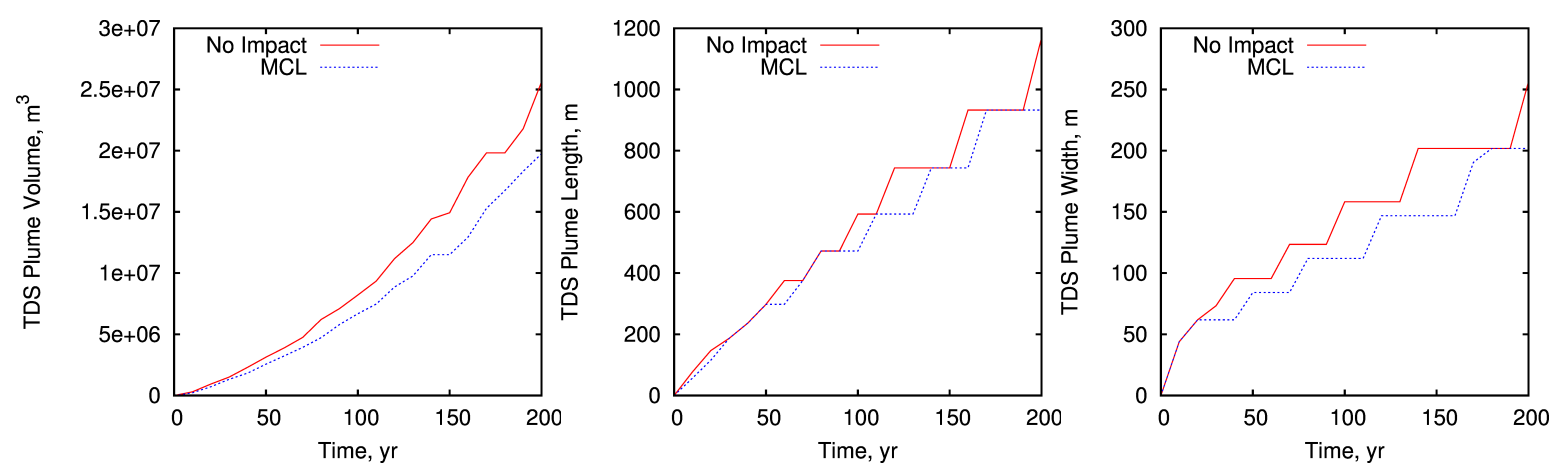

Figure 5.6. TDS plume volume, length and width during 200 years of well leakage.
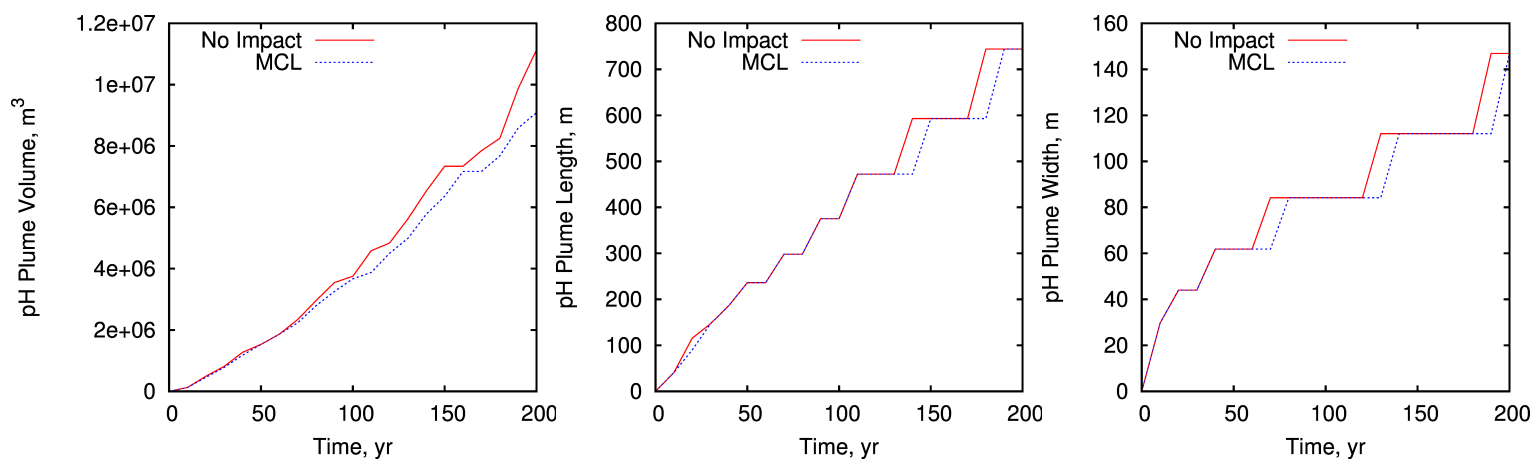

Figure 5.7. $\mathrm{pH}$ plume volume, length and width during 200 years of well leakage. 

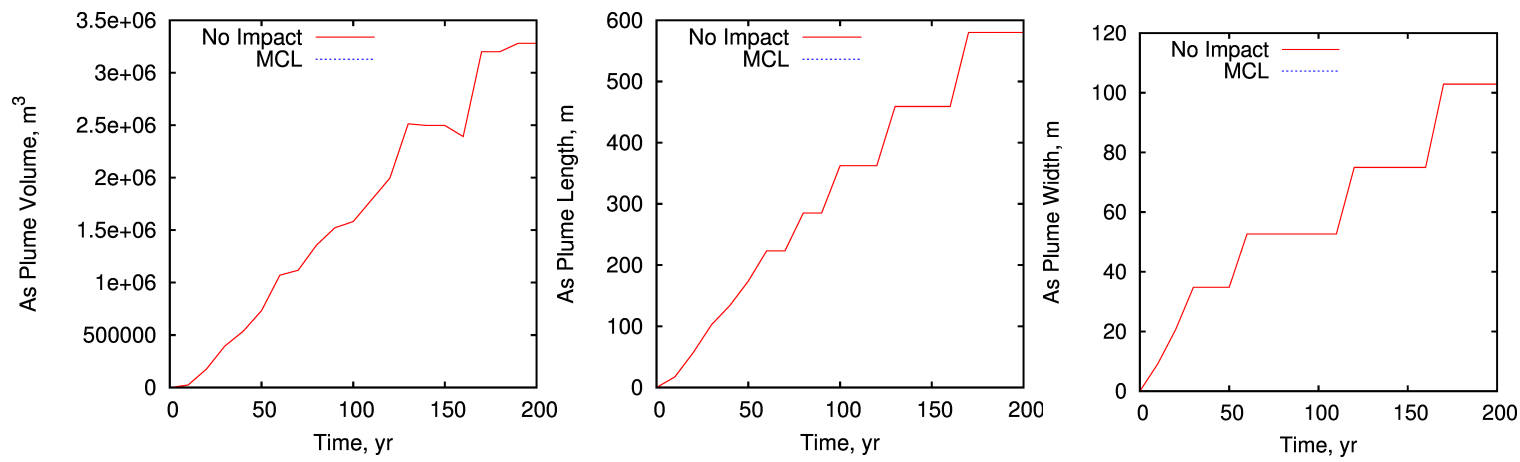

Figure 5.8. Arsenic plume volume, length, and width during 200 years of well leakage. Arsenic does not exceed the MCL threshold for this simulation.
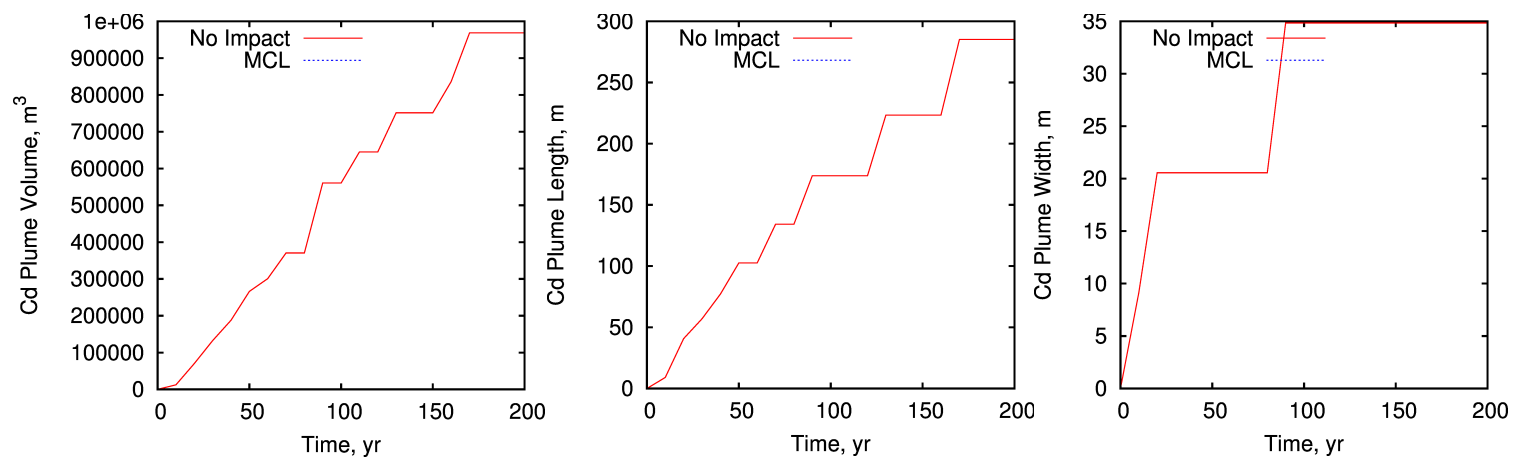

Figure 5.9. Cadmium plume volume, length, and width during 200 years of well leakage. Cadmium does not exceed the MCL threshold for this simulation.
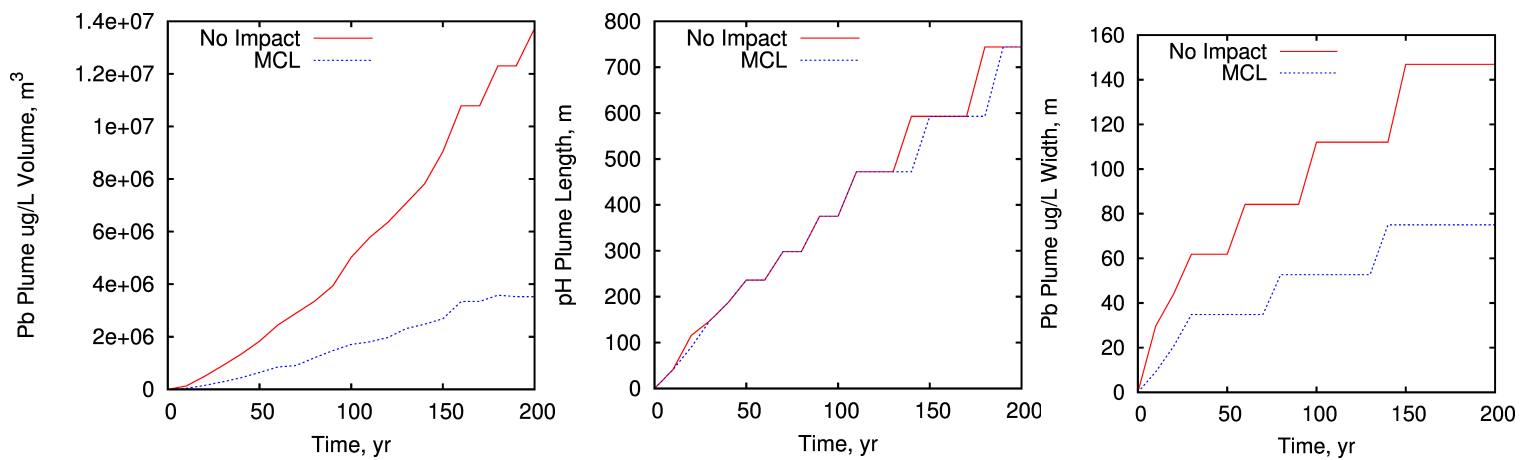

Figure 5.10. Lead plume volume, length, and width during 200 years of well leakage.

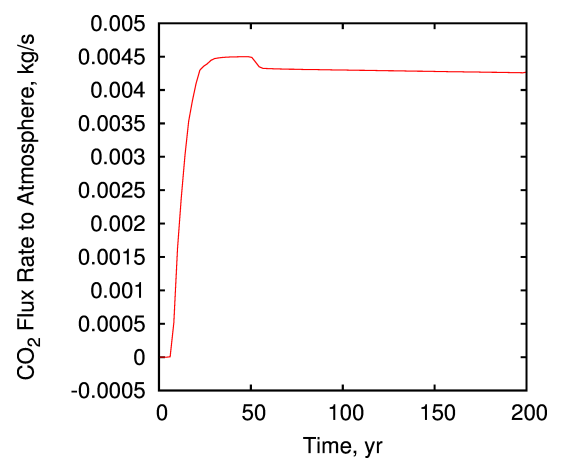

Figure 5.11. Carbon dioxide flux to the atmosphere during 200 years of well leakage. 



\subsection{Uncertainty Quantification}

\subsection{Sampling}

The uncertainty analysis was done with the input parameters and ranges shown in Table 6.1. Latin Hypercube sampling was used to generate 1024 samples for input into STOMP. All variables were assumed to have a uniform distribution.

Table 6.1. Input parameters and their ranges for uncertainty quantification.

\begin{tabular}{|c|c|c|c|c|c|}
\hline Variable & Name & Description & Min & Max & Unit \\
\hline 1 & Smax & Maximum $\mathrm{CO}_{2}$ saturation in reservoir & 0.35 & 1 & \\
\hline 2 & Pmax & Maximum $\mathrm{CO}_{2}$ pressure in reservoir & 4.85 & 36 & $\mathrm{MPa}$ \\
\hline 3 & $\mathrm{Kw}$ & Wellbore cement permeability & -14 & -8 & $\log m^{2}$ \\
\hline 4 & nacl & $\mathrm{NaCl}$ concentration in brine & 0.5 & 5.4 & $\mathrm{~mol} / \mathrm{L}$ \\
\hline 5 & dol & Dolomite volume fraction of solid phase & 0.01 & 0.1 & \\
\hline 6 & kao & Kaolinite volume fraction of solid phase & 0.01 & 0.1 & \\
\hline 7 & ill & Illite volume fraction of solid phase & 0.01 & 0.1 & \\
\hline 8 & logk_cal & Calcite equilibrium coefficient $(\log \mathrm{K})$ & 1.347 & 2.347 & $\log$ \\
\hline 9 & logk_dol & Dolomite equilibrium coefficient ( $\log \mathrm{K})$ & 3.799 & 4.799 & $\log$ \\
\hline 10 & logk_kao & Kaolinite equilibrium coefficient $(\log \mathrm{K})$ & 5.972 & 6.972 & $\log$ \\
\hline 11 & logk_ill & Illite equilibrium coefficient $(\log K)$ & 9.526 & 10.526 & $\log$ \\
\hline 12 & logk_cer & Cerussite equilibrium coefficient $(\log \mathrm{K})$ & -3.463 & -2.463 & $\log$ \\
\hline 13 & logk_ota & Otavite equilibrium coefficient $(\log K)$ & -2.273 & -1.273 & $\log$ \\
\hline 14 & Cal_c & Calcite_c surface complexation sites & -3.99 & -2.99 & $\log \mathrm{mol} / \mathrm{L}$ \\
\hline 15 & Cal_s & Calcite_s surface complexation sites & -5.54 & -4.54 & $\log \mathrm{mol} / \mathrm{L}$ \\
\hline 16 & Cal_w & Calcite_w surface complexation sites & -4 & -3 & $\log \mathrm{mol} / \mathrm{L}$ \\
\hline 17 & Ill_b & Illite basal surface complexation sites & -5.08 & -4.08 & $\log \mathrm{mol} / \mathrm{L}$ \\
\hline 18 & Ill_e & Illite edge surface complexation sites & -4.61 & -3.61 & $\log \mathrm{mol} / \mathrm{L}$ \\
\hline 19 & Kao_b & Kaolinite basal surface complexation sites & -5.67 & -4.67 & $\log \mathrm{mol} / \mathrm{L}$ \\
\hline 20 & Kao_e & Kaolinite edge surface complexation sites & -4.54 & -3.54 & $\log \mathrm{mol} / \mathrm{L}$ \\
\hline
\end{tabular}

The first three input parameters feed the Wellbore Leakage ROM. Two other input parameters are assumed to be constant: the distance between the injection and leaky well is assumed to be $500 \mathrm{~m}$ and the reservoir depth is assumed to be $1800 \mathrm{~m}$. The resulting leak rates for all 1024 samples range up to $0.1 \mathrm{~kg} / \mathrm{s}$ for $\mathrm{CO}_{2}$ (Figure 6.1) and $0.01 \mathrm{~kg} / \mathrm{s}$ for brine (Figure 6.2). 


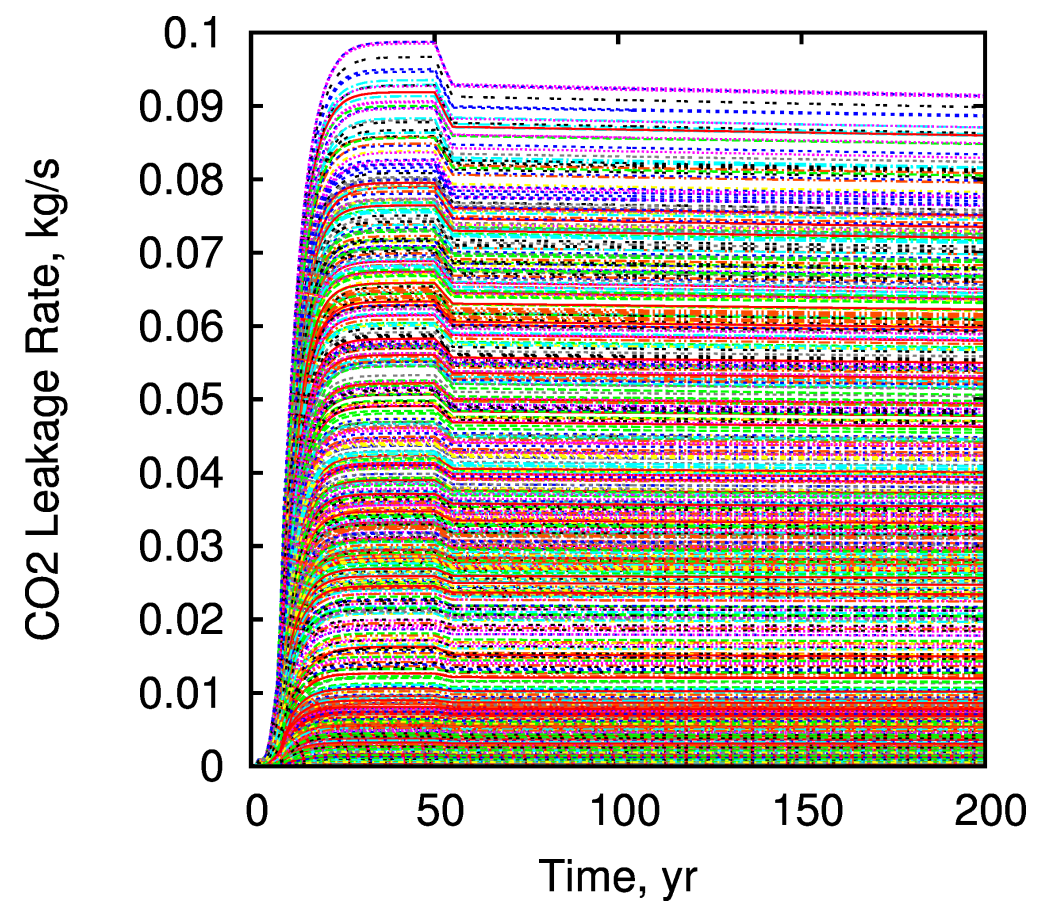

Figure 6.1. Well $\mathrm{CO}_{2}$ leakage rate $(\mathrm{kg} / \mathrm{s})$ vs. time for 1024 samples of input parameters.

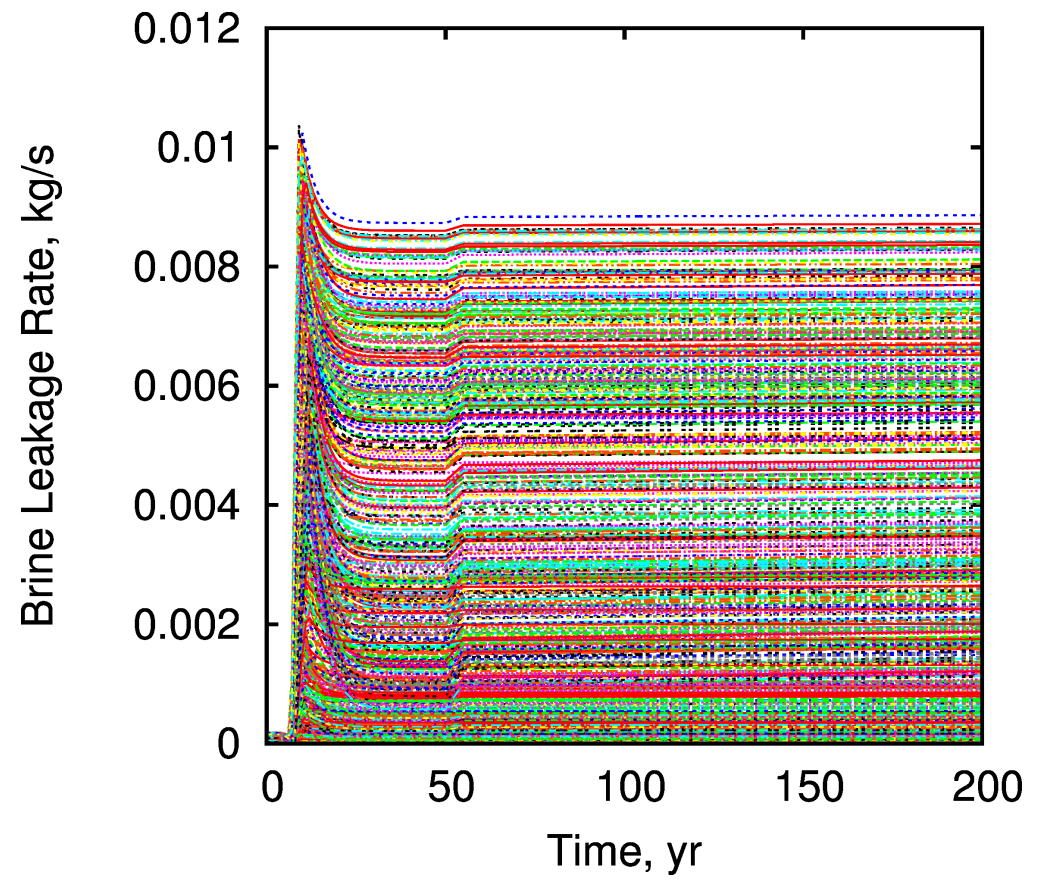

Figure 6.2. Well brine leakage rate $(\mathrm{kg} / \mathrm{s})$ vs. time for 1024 samples of input parameters. 


\subsection{Response Surface}

Sixteen output variables were used to construct the response surface (Table 6.2).

Table 6.2. Output variables used to construct the response surface.

\begin{tabular}{cllc}
\hline Variable & Name & \multicolumn{1}{c}{ Description } & Unit \\
\hline 1 & flux & $\mathrm{CO}_{2}$ flux to atmosphere & $\mathrm{kg} / \mathrm{s}$ \\
2 & tdsvol & Volume of TDS plume & $\mathrm{m}^{3}$ \\
3 & tdslen & Length of TDS plume & $\mathrm{m}$ \\
4 & tdswid & Width of TDS plume & $\mathrm{m}$ \\
5 & phvol & Volume of pH plume & $\mathrm{m}^{3}$ \\
6 & phlen & Length of pH plume & $\mathrm{m}$ \\
7 & phwid & Width of pH plume & $\mathrm{m}$ \\
8 & asvol & Volume of arsenic plume & $\mathrm{m}^{3}$ \\
9 & aslen & Length of arsenic plume & $\mathrm{m}$ \\
10 & aswid & Width of arsenic plume & $\mathrm{m}$ \\
11 & cdvol & Volume of cadmium plume & $\mathrm{m}^{3}$ \\
12 & cdlen & Length of cadmium plume & $\mathrm{m}$ \\
13 & cdwid & Width of cadmium plume & $\mathrm{m}$ \\
14 & pbvol & Volume of lead plume & $\mathrm{m}^{3}$ \\
15 & pblen & Length of lead plume & $\mathrm{m}$ \\
16 & pbwid & Width of lead plume & $\mathrm{m}$ \\
\hline
\end{tabular}

The threshold values for determining the sizes of the plumes were given previously in Table 5.1. The input parameter names and descriptions were given in Table 6.1. The growth of the pH plumes for all 1024 parameter samples is shown in Figure 6.3 (MCL limits) and Figure 6.4 (no-impact limits), and the growth of the TDS plumes with time is shown in Figure 6.5 (MCL limits) and Figure 6.6 (no-impact limits). The growth of the plume volume is nearly linear in most cases, as are the increases in length and width of the plume, although the effects of grid spacing are more pronounced for the latter two variables. The difference between the no-impact and MCL-limits results for $\mathrm{pH}$ and TDS are not notable, because the limits themselves are not greatly different.

The growth of the As plume with time is shown in Figure 6.7 (MCL limits) and Figure 6.8 (no-impact limits), and the growth of the Cd plume with time is shown in Figure 6.9 (MCL limits) and Figure 6.10 (no-impact limits). For the MCL limits, very few of the parameter samples resulted in As and Cd concentrations above the threshold values (Table 6.3). While 89 to $91 \%$ of the samples resulted in $\mathrm{pH}$ or TDS that exceeded either the MCL or no-impact threshold limits, only $17 \%$ of the samples resulted in Cd plumes and $37 \%$ of the samples resulted in As plumes that exceeded the MCL limits. A significantly greater number of $\mathrm{As}(61 \%)$ and $\mathrm{Cd}(62 \%)$ plumes exceeded the lower no-impact threshold limits. The growth of the $\mathrm{Pb}$ plume with time is shown in Figure 6.11 (MCL limits) and Figure 6.12 (no-impact limits). While 63\% of the samples resulted in $\mathrm{Pb}$ plumes that exceed the MCL threshold limits, 91\% exceeded the no-impact limits. Overall, the trace metal plumes were larger for the lower no-impact limits. Carbon dioxide flux with time for all 1024 parameter samples is shown in Figure 6.13. Sixty-nine 
percent of the sample runs resulted in $\mathrm{CO}_{2}$ flux to the atmosphere. Of those runs, over $50 \%$ resulted in all of the $\mathrm{CO}_{2}$ leaked into the aquifer escaping to the atmosphere.
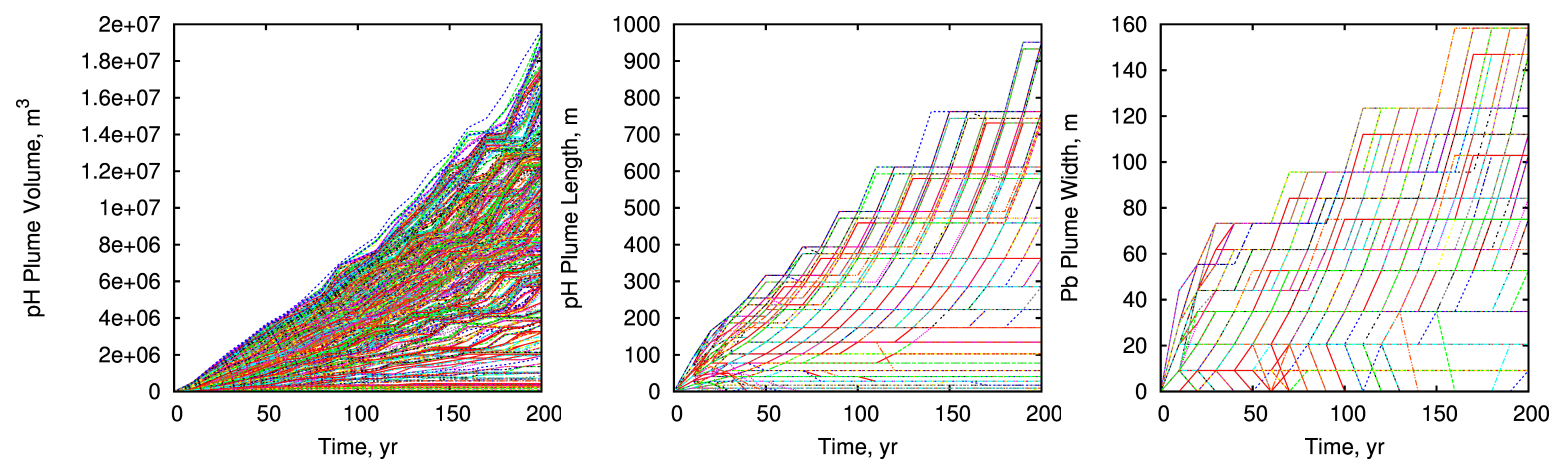

Figure 6.3. Growth of $\mathrm{pH}$ plume volume, length, and width with time for 1024 samples using MCL limits.
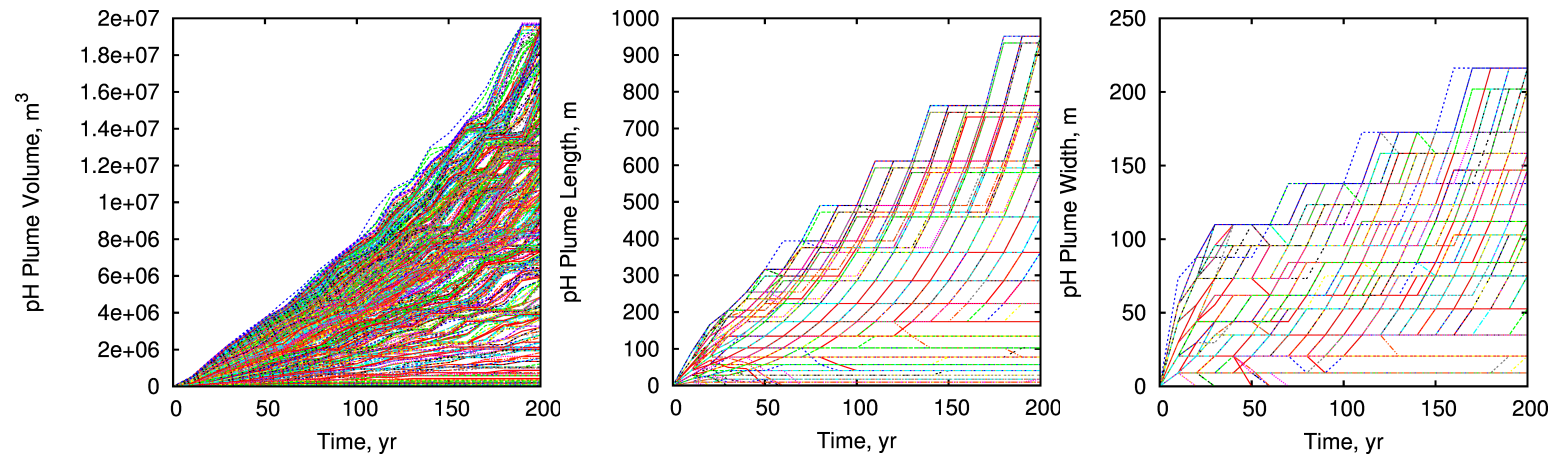

Figure 6.4. Growth of $\mathrm{pH}$ plume volume, length, and width with time for 1024 samples using no-impact limits.
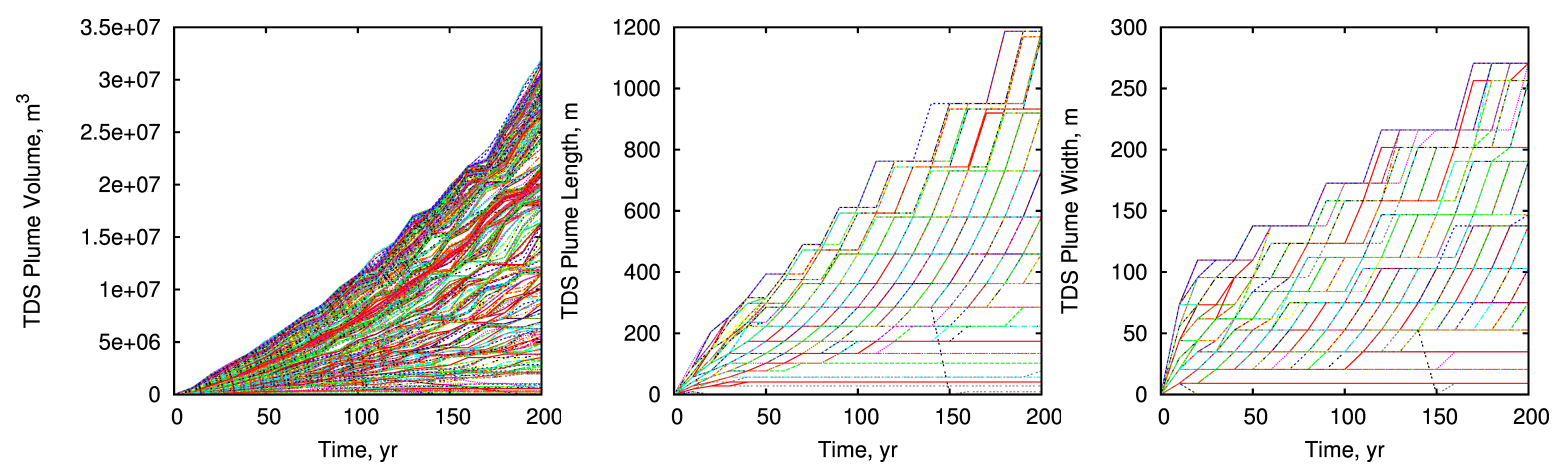

Figure 6.5. Growth of TDS plume volume, length, and width with time for 1024 samples using MCL limits. 

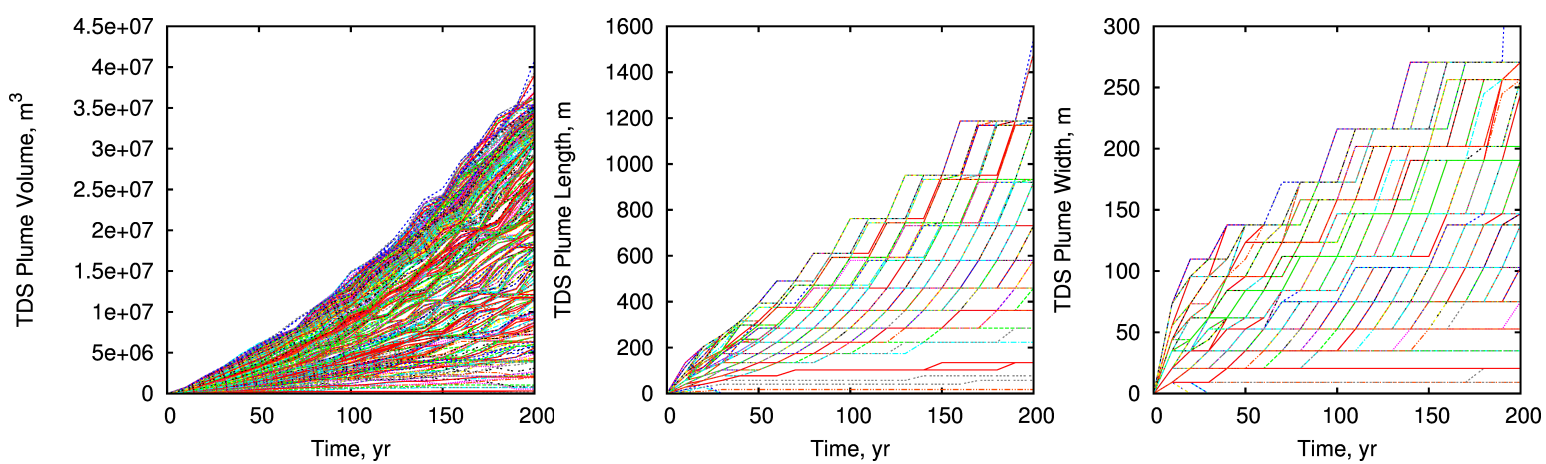

Figure 6.6. Growth of TDS plume volume, length, and width with time for 1024 samples using no-impact limits.
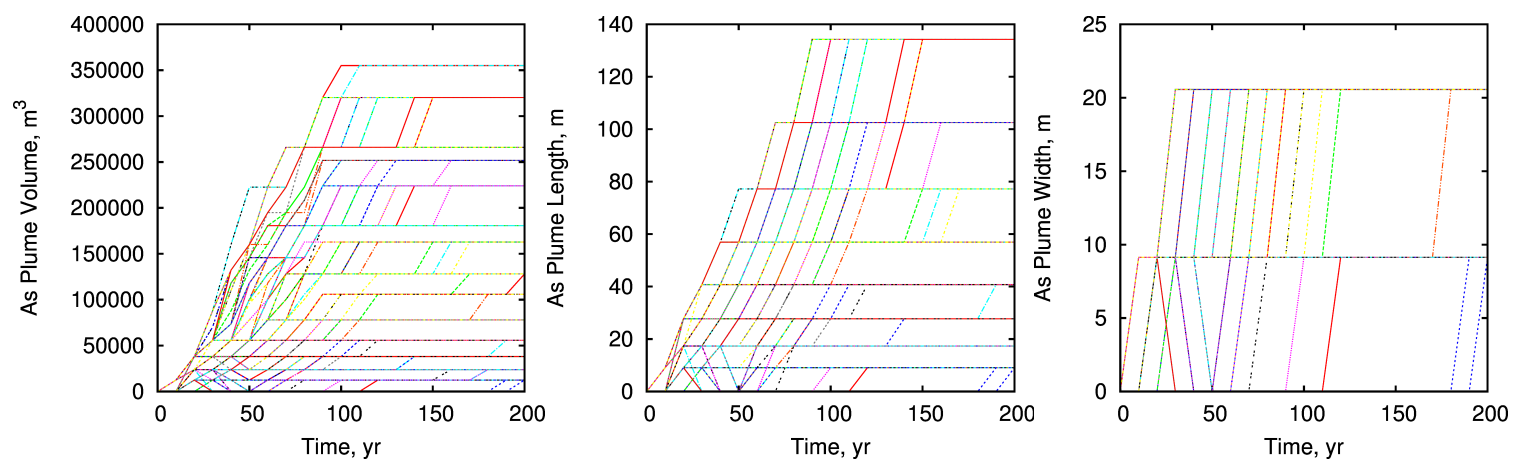

Figure 6.7. Growth of As plume volume, length, and width with time for 1024 samples using MCL limits.
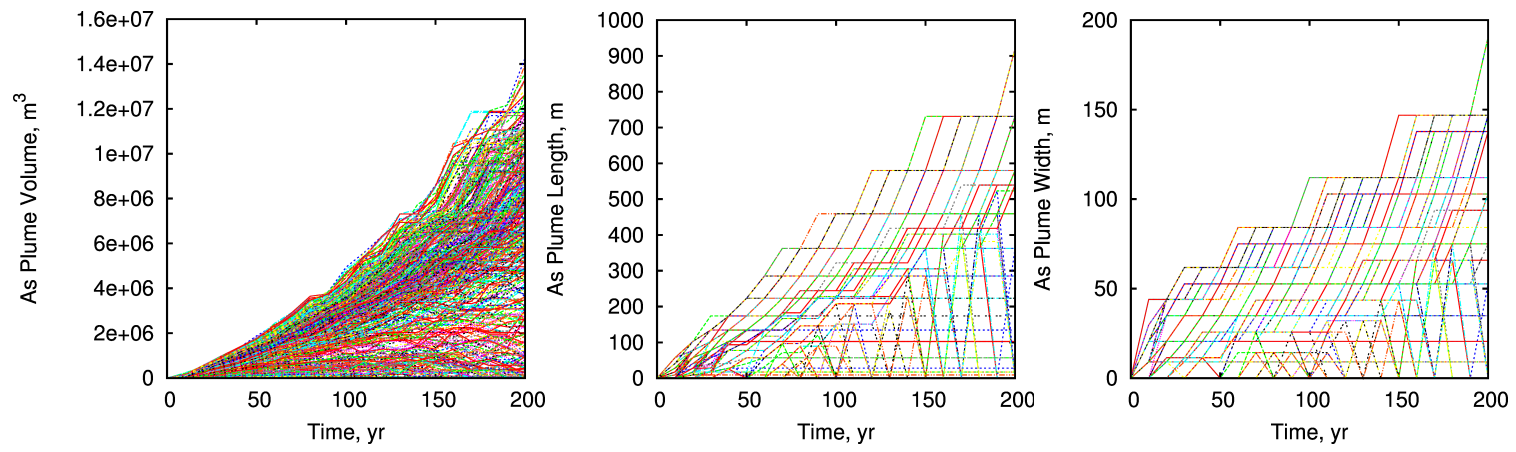

Figure 6.8. Growth of As plume volume, length, and width with time for 1024 samples using no-impact limits. 

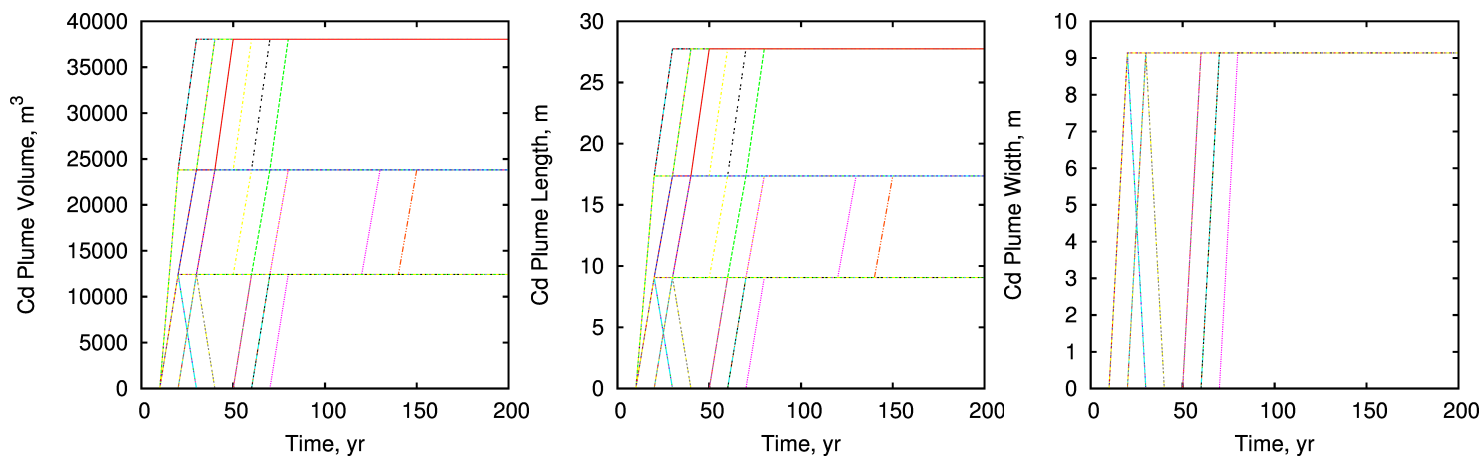

Figure 6.9. Growth of $\mathrm{Cd}$ plume volume, length, and width with time for 1024 samples using MCL limits.
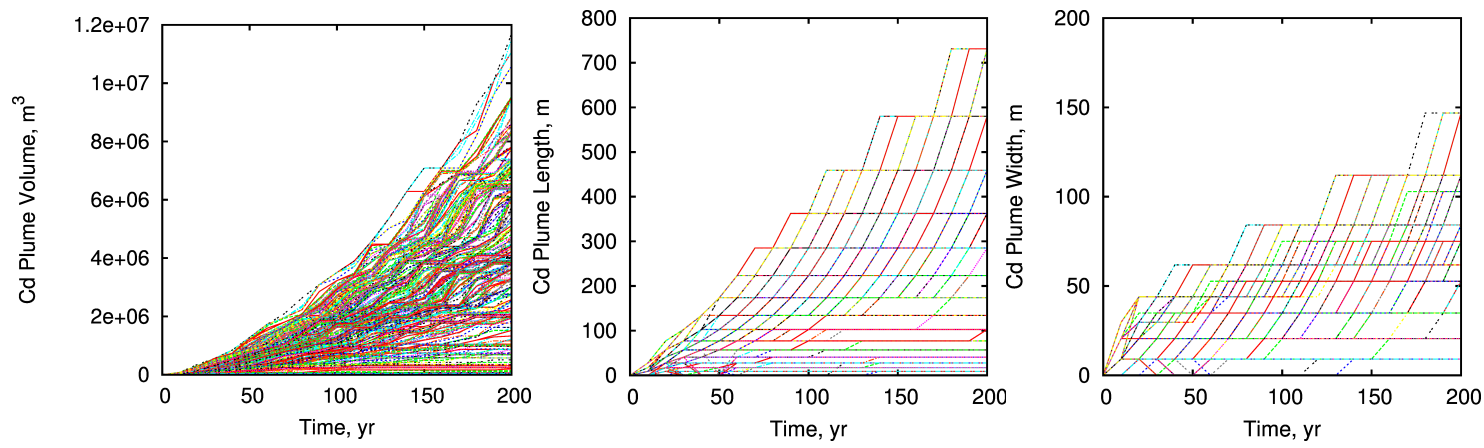

Figure 6.10. Growth of Cd plume volume, length, and width with time for 1024 samples using no-impact limits.
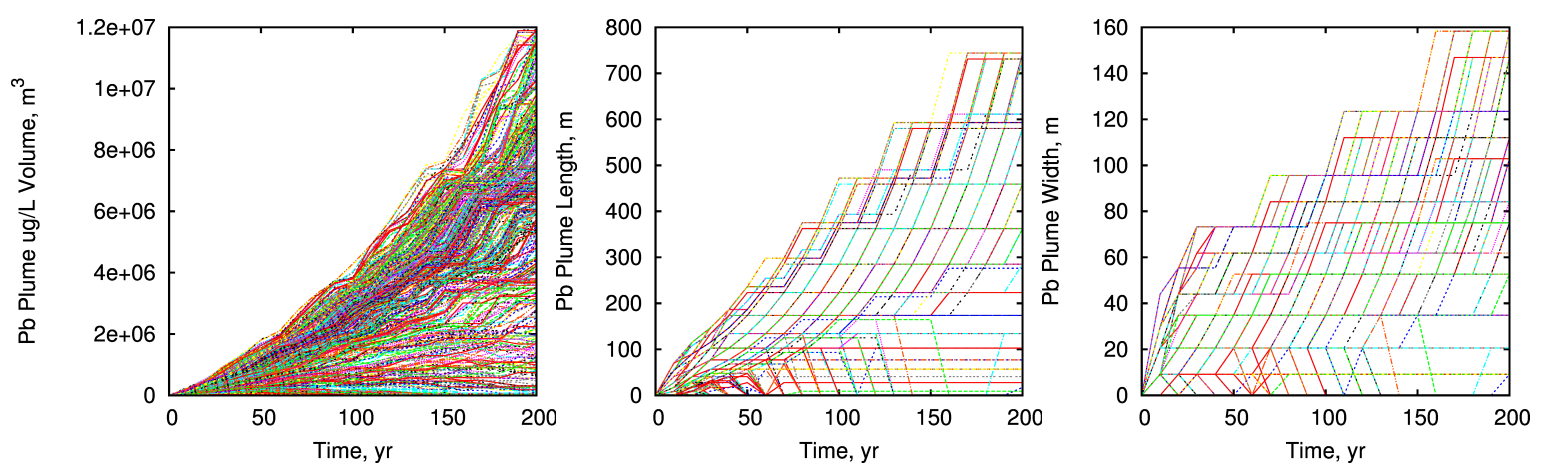

Figure 6.11. Growth of $\mathrm{Pb}$ plume volume, length, and width with time for 1024 samples using MCL limits. 

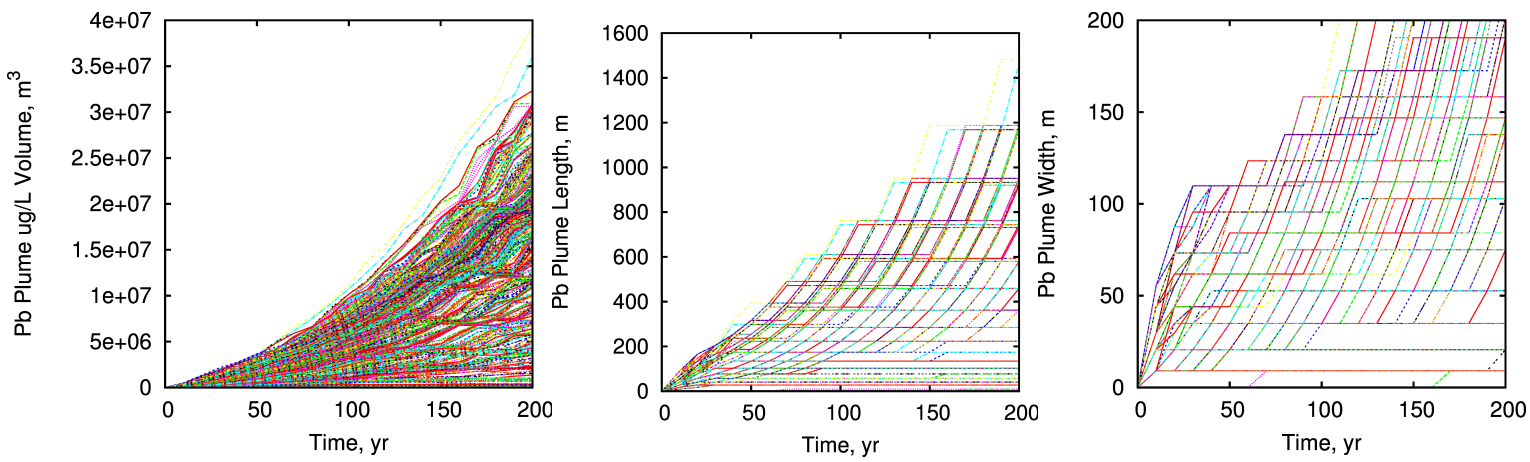

Figure 6.12. Growth of $\mathrm{Pb}$ plume volume, length, and width with time for 1024 samples using no-impact limits.

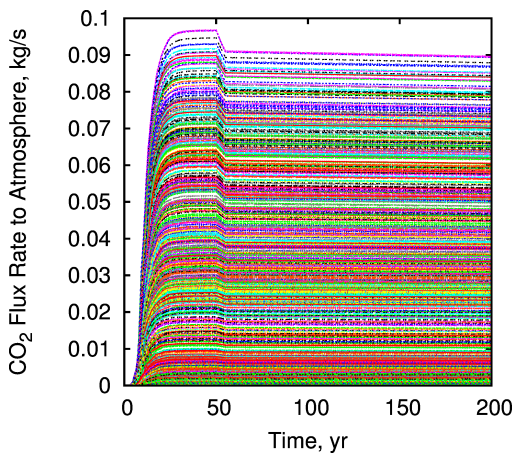

Figure 6.13. $\mathrm{CO}_{2}$ flux to atmosphere with time for 1024 samples using MCL limits.

Table 6.3. Percentage of 1024 samples resulting in plumes exceeding threshold limits or $\mathrm{CO}_{2}$ flux to atmosphere.

\begin{tabular}{lcc}
\hline \multicolumn{1}{c}{ Variable } & $\begin{array}{c}\text { Runs Where Values } \\
\text { Exceeded No-Impact Limits }\end{array}$ & $\begin{array}{c}\text { Runs Where Values } \\
\text { Exceeded MCL Limits }\end{array}$ \\
\hline As Volume & $62 \%$ & $37 \%$ \\
$\mathrm{Cd}$ Volume & $61 \%$ & $14 \%$ \\
$\mathrm{~Pb}$ Volume & $91 \%$ & $63 \%$ \\
$\mathrm{pH}$ & $89 \%$ & $89 \%$ \\
$\mathrm{TDS}$ Volume & $91 \%$ & $91 \%$ \\
$\mathrm{CO}_{2}$ Flux & $69 \%$ & $69 \%$ \\
\hline
\end{tabular}

\subsection{Transformation of the Response Surface}

Each of the 16 output variables was recorded at 21 different times, from 0 to 200 years in 10 -year increments. Because of this, the original response surface had 16 variables $\times 21$ times $=336$ output variables. The response surface was transformed so that time became an additional input parameter, and the output variables became functions of time. The transformed response surface then effectively had $1024 \times 21=21,504$ input samples, one additional input parameter (time), and only 16 output variables. 
A second transformation of the response-surface input parameters was performed to decouple the Wellbore Leakage ROM from the groundwater geochemistry ROM. For a given input sample at a particular time, input parameters 1-3 from Table 6.1 were used to run the Wellbore Leakage ROM and to calculate the $\mathrm{CO}_{2}$ leak rate and the brine leak rate, as well as the cumulative mass of $\mathrm{CO}_{2}$ and brine leaked up to that time. These four values then became four new input parameters, replacing the three input parameters for the Wellbore Leakage ROM. The transformed list of input parameters is shown in Table 6.4 .

Table 6.4. Transformed input parameters and their ranges for uncertainty quantification.

\begin{tabular}{|c|c|c|c|c|c|}
\hline Variable & Name & Description & Min & $\operatorname{Max}$ & Unit \\
\hline 1 & co2mass & Cumulative mass of $\mathrm{CO}_{2}$ leaked & 0 & 558 & $\mathrm{~kg}$ \\
\hline 2 & co2rate & $\mathrm{CO}_{2}$ leak rate & 0 & $9.87 \mathrm{E}-2$ & $\mathrm{~kg} / \mathrm{s}$ \\
\hline 3 & brinemass & Cumulative mass of brine leaked & 0 & 53.7 & $\mathrm{~kg}$ \\
\hline 4 & brinerate & Brine leak rate & 0 & $1.02 \mathrm{E}-2$ & $\mathrm{~kg} / \mathrm{s}$ \\
\hline 5 & nacl & $\mathrm{NaCl}$ concentration in brine & 0.5 & 5.4 & $\mathrm{~mol} / \mathrm{L}$ \\
\hline 6 & dol & Dolomite & 0.01 & 0.1 & $\begin{array}{l}\text { volume fraction of solid } \\
\text { phase }\end{array}$ \\
\hline 7 & kao & Kaolinite & 0.01 & 0.1 & $\begin{array}{l}\text { volume fraction of solid } \\
\text { phase }\end{array}$ \\
\hline 8 & ill & Illite & 0.01 & 0.1 & $\begin{array}{l}\text { volume fraction of solid } \\
\text { phase }\end{array}$ \\
\hline 9 & logk_cal & Calcite equilibrium coefficient $(\log K)$ & 1.347 & 2.347 & $\log$ \\
\hline 10 & logk_dol & Dolomite equilibrium coefficient ( $\log \mathrm{K})$ & 3.799 & 4.799 & $\log$ \\
\hline 11 & logk_kao & Kaolinite equilibrium coefficient $(\log \mathrm{K})$ & 5.972 & 6.972 & $\log$ \\
\hline 12 & logk_ill & Illite equilibrium coefficient $(\log K)$ & 9.526 & 10.526 & $\log$ \\
\hline 13 & logk_cer & Cerussite equilibrium coefficient $(\log \mathrm{K})$ & -3.463 & -2.463 & $\log$ \\
\hline 14 & logk_ota & Otavite equilibrium coefficient $(\log \mathrm{K})$ & -2.273 & -1.273 & $\log$ \\
\hline 15 & Cal_c & Calcite_c surface complexation sites & -3.99 & -2.99 & $\log \mathrm{mol} / \mathrm{L}$ \\
\hline 16 & Cal_s & Calcite_s surface complexation sites & -5.54 & -4.54 & $\log \mathrm{mol} / \mathrm{L}$ \\
\hline 17 & Cal_w & Calcite_w surface complexation sites & -4 & -3 & $\log \mathrm{mol} / \mathrm{L}$ \\
\hline 18 & Ill_b & Illite basal surface complexation sites & -5.08 & -4.08 & $\log \mathrm{mol} / \mathrm{L}$ \\
\hline 19 & Ill_e & Illite edge surface complexation sites & -4.61 & -3.61 & $\log \mathrm{mol} / \mathrm{L}$ \\
\hline 20 & Kao_b & Kaolinite basal surface complexation sites & -5.67 & -4.67 & $\log \mathrm{mol} / \mathrm{L}$ \\
\hline 21 & Kao_e & Kaolinite edge surface complexation sites & -4.54 & -3.54 & $\log \mathrm{mol} / \mathrm{L}$ \\
\hline 22 & Time & Time & 0 & 200 & Years \\
\hline
\end{tabular}

\subsection{Parameter Ranking}

Model input parameters were ranked for relative importance using the MARS method (Friedman 1991). MARS is a nonparametric regression technique that gives an importance score between 0 and 100 for each input variable.

The most significant parameter for the TDS plume size is the cumulative mass of $\mathrm{CO}_{2}$ leaked from the well (Figure 6.14 and Figure 6.15). This indicates that the increases in calcium and carbonate due to dissolution of calcite in response to lowered $\mathrm{pH}$ in the aquifer have a stronger influence on TDS than the 
increases in sodium, chloride, and trace metals from the relatively smaller brine leak. The $\mathrm{pH}$ plume size is influenced by the $\mathrm{CO}_{2}$ leakage rate and by the equilibrium coefficients for calcite and dolomite (Figure 6.16 and Figure 6.17). Dissolution of $\mathrm{CO}_{2}$ in groundwater lowers the $\mathrm{pH}$, and dissolution/precipitation of calcite and dolomite also involve $\mathrm{H}^{+}$(Table 3.2). There is little difference between the parameter sensitivity for $\mathrm{pH}$ and TDS using the no-impact and MCL limits.

Both the As (Figure 6.18 and Figure 6.19) and Cd (Figure 6.20 and Figure 6.21) plumes are strongly influenced by the concentration of $\mathrm{NaCl}$ in the brine, because the As and $\mathrm{Cd}$ concentrations in the brine are proportional to the $\mathrm{NaCl}$ concentrations. Using the MCL limits, sorption and secondary mineral precipitation seem to have little influence, likely because As and $\mathrm{Cd}$ exceed the threshold limits only for the highest values of brine leak rate and $\mathrm{NaCl}$ concentrations. Carbonate equilibria and clay sorption have more influence when no-impact limits are used, but still are of only secondary importance compared to the leak parameters.

The sizes of the lead plumes are influenced by the brine leak rate, the $\mathrm{NaCl}$ concentration, and to a lesser extent the $\mathrm{CO}_{2}$ leak rate, the equilibrium of calcite and dolomite, and the number of illite and kaolinite surface sites (Figure 6.22 and Figure 6.23). The dependence on the $\mathrm{CO}_{2}$ leak rate and on the equilibrium coefficients for calcite and dolomite indicate a dependence on $\mathrm{pH}$, which would influence the amount of $\mathrm{Pb}$ sorbed on illite and kaolinite surface sites. MARS parameter ranking confirms that the major influence on the $\mathrm{CO}_{2}$ flux to the atmosphere is the $\mathrm{CO}_{2}$ well leak rate (Figure 6.24). Time is a significant parameter for all of the output variables because the plume volumes grow linearly with time.

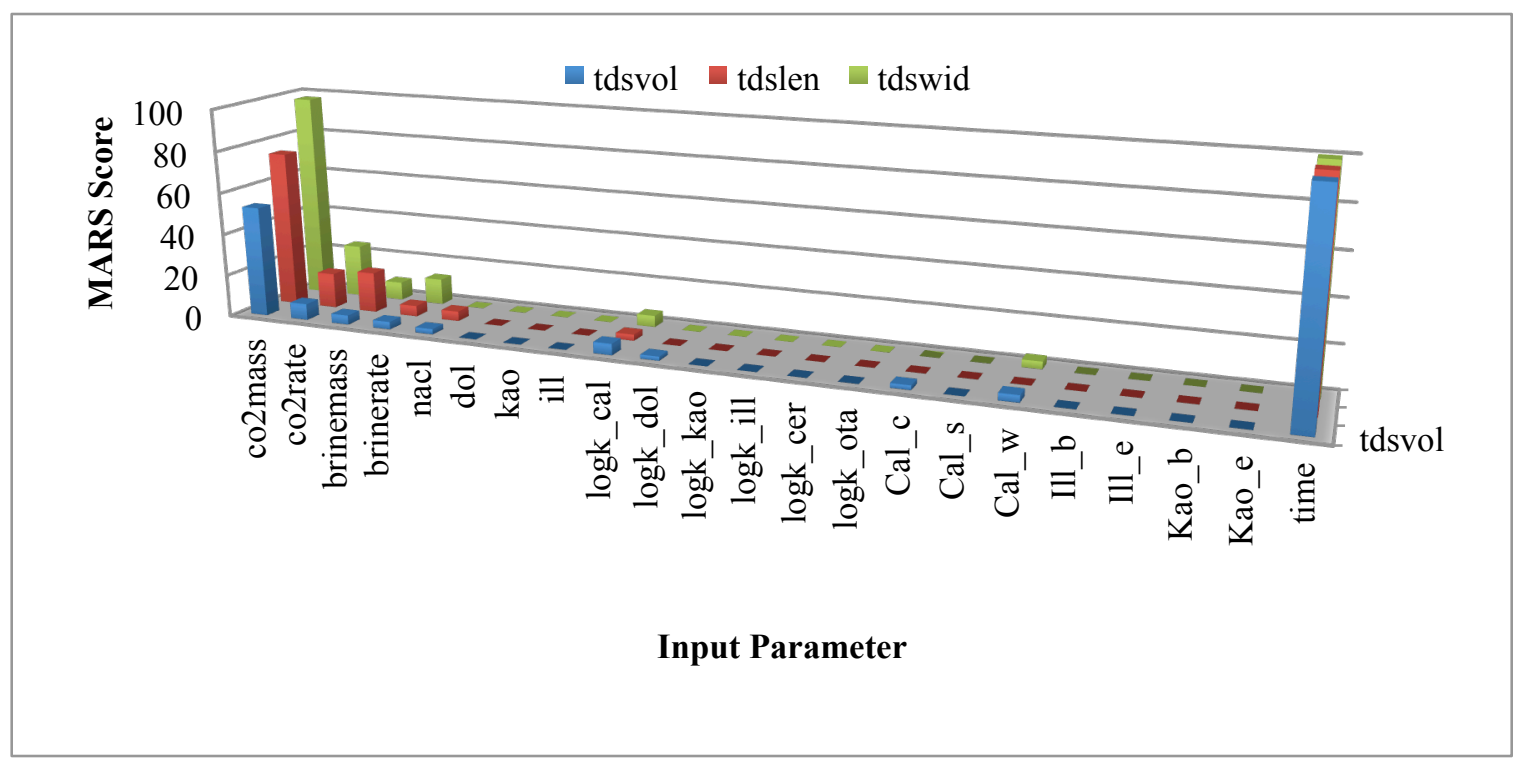

Figure 6.14. Input parameter ranking for TDS plume size using MCL limits. 


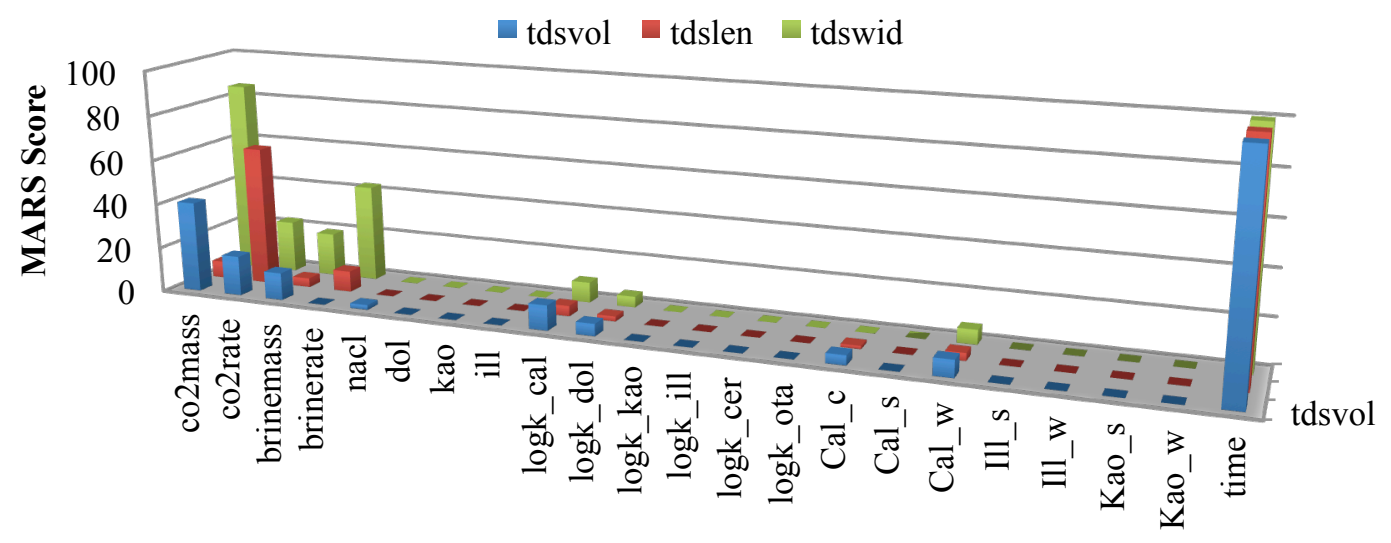

Input Parameter

Figure 6.15. Input parameter ranking for TDS plume size using no-impact limits.

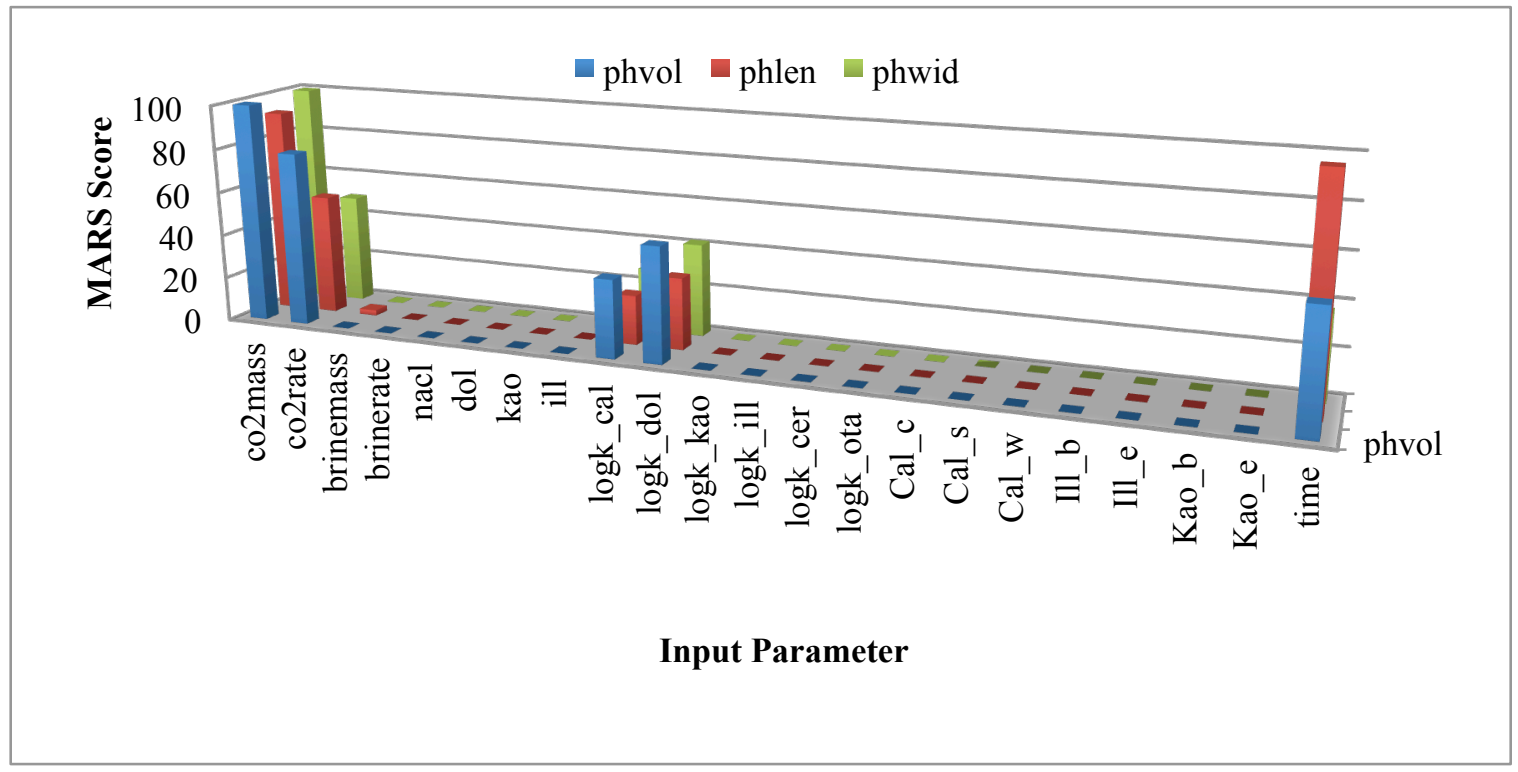

Figure 6.16. Input parameter ranking for $\mathrm{pH}$ plume size using MCL limits. 


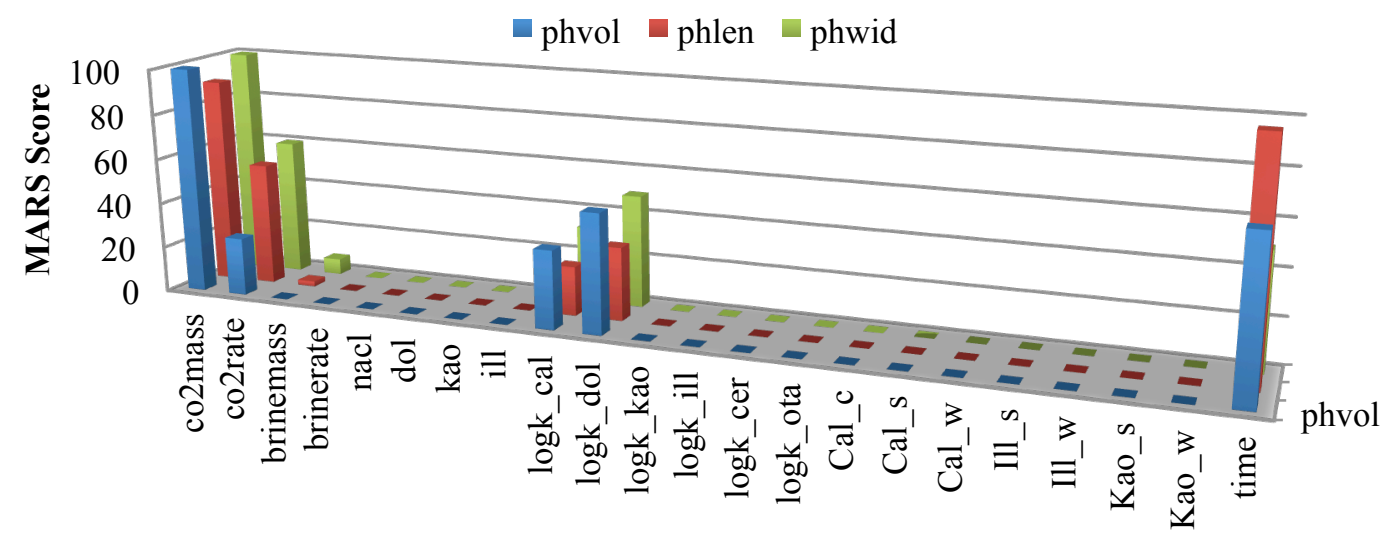

Input Parameter

Figure 6.17. Input parameter ranking for $\mathrm{pH}$ plume size using no-impact limits.

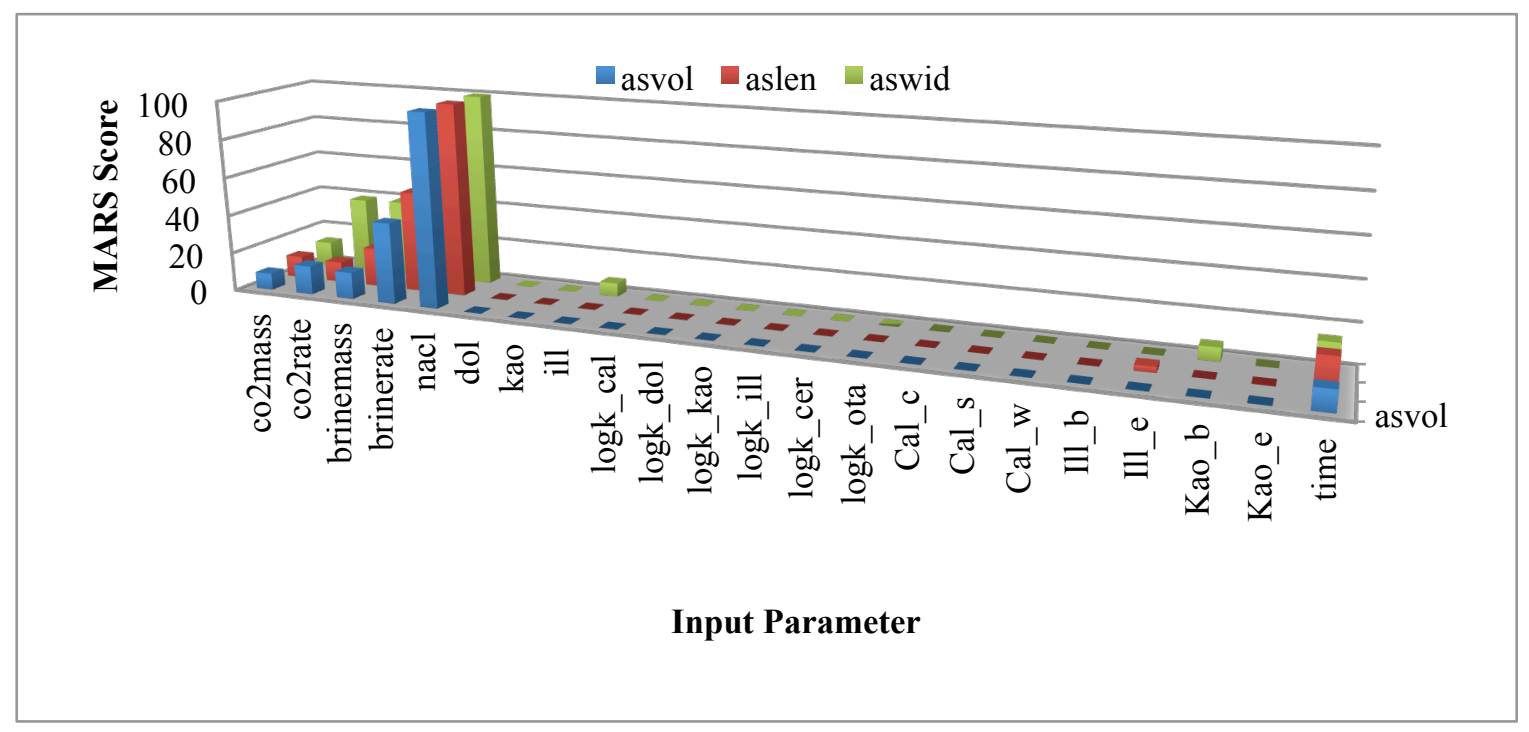

Figure 6.18. Input parameter ranking for As plume size using MCL limits. 


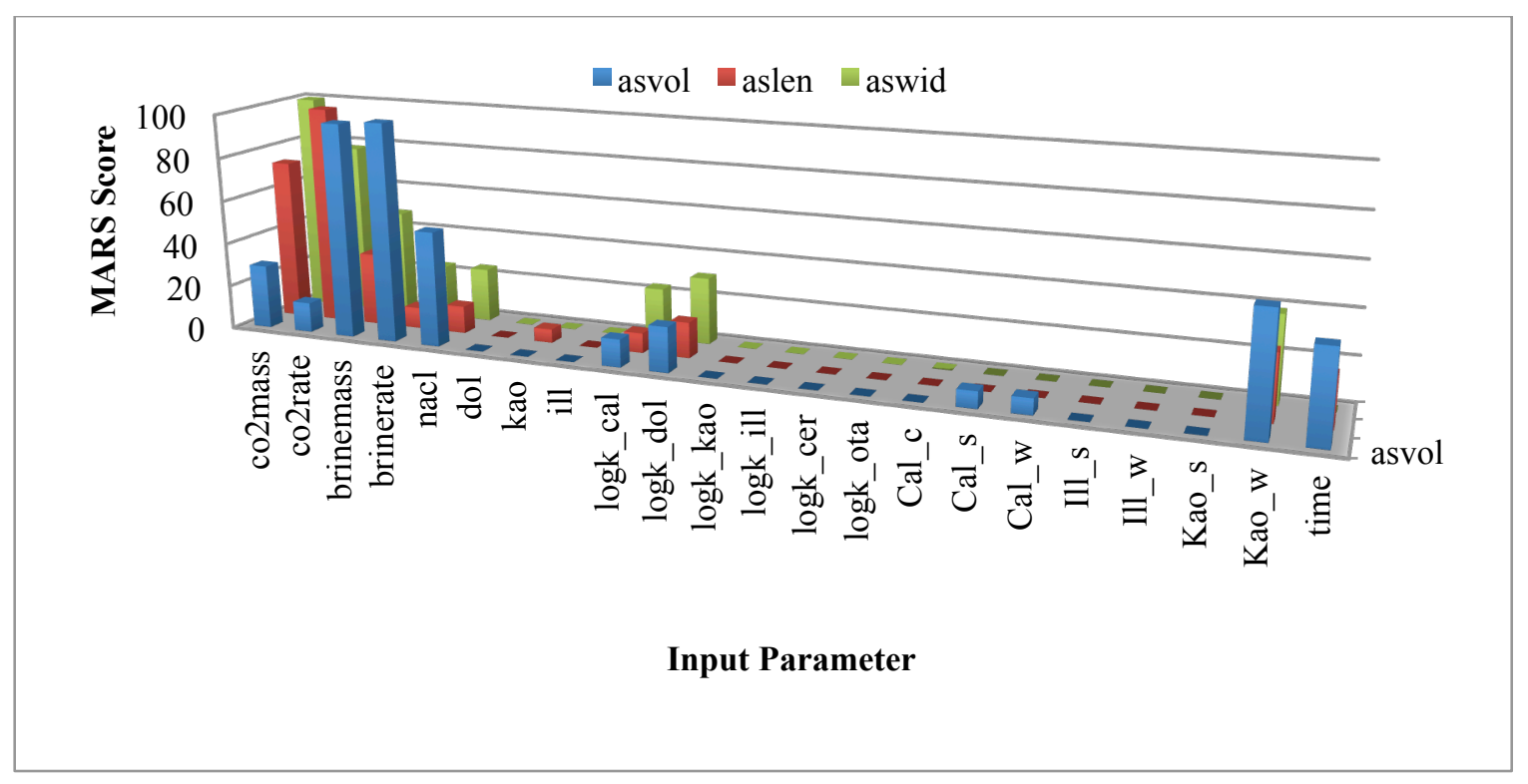

Figure 6.19. Input parameter ranking for As plume size using no-impact limits.

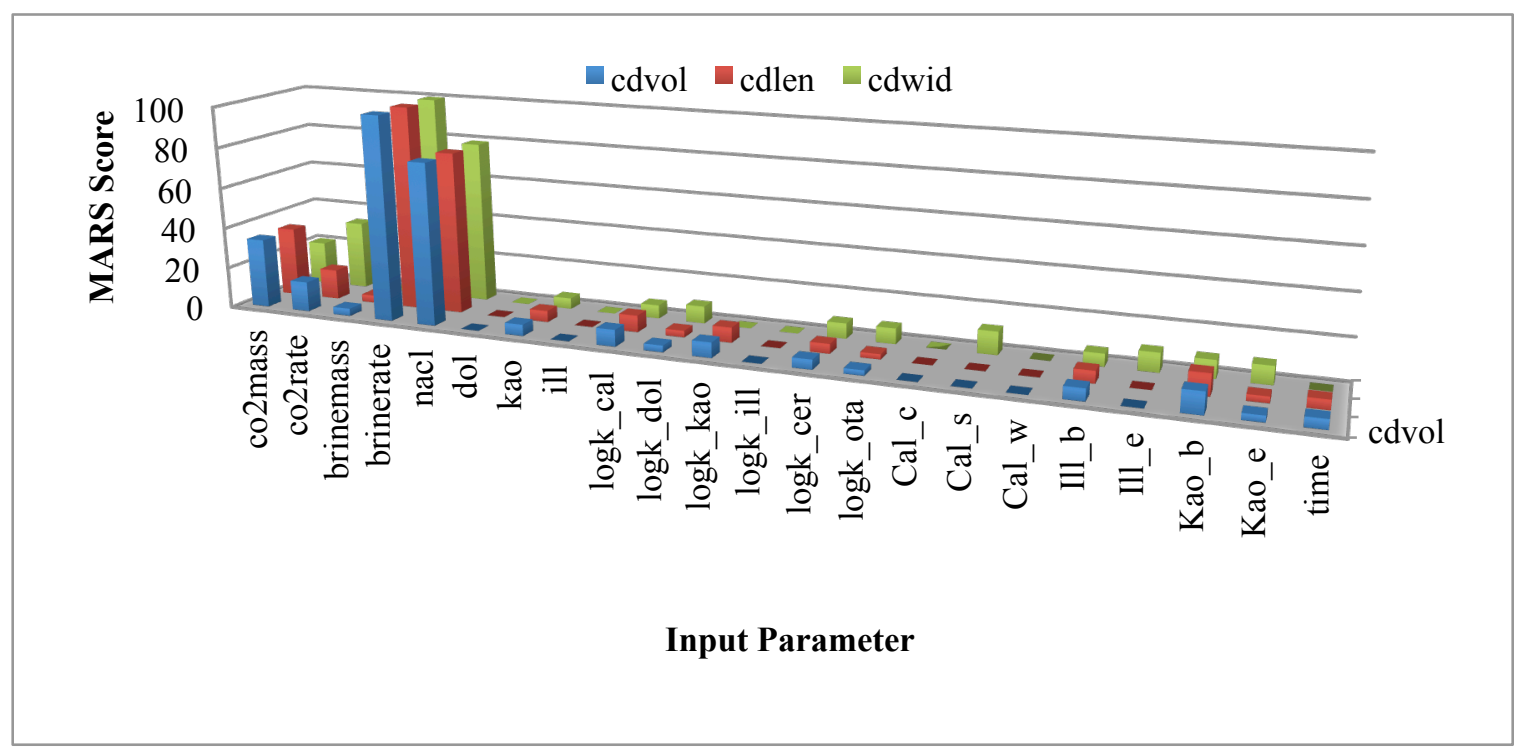

Figure 6.20. Input parameter ranking for Cd plume size using MCL limits. 


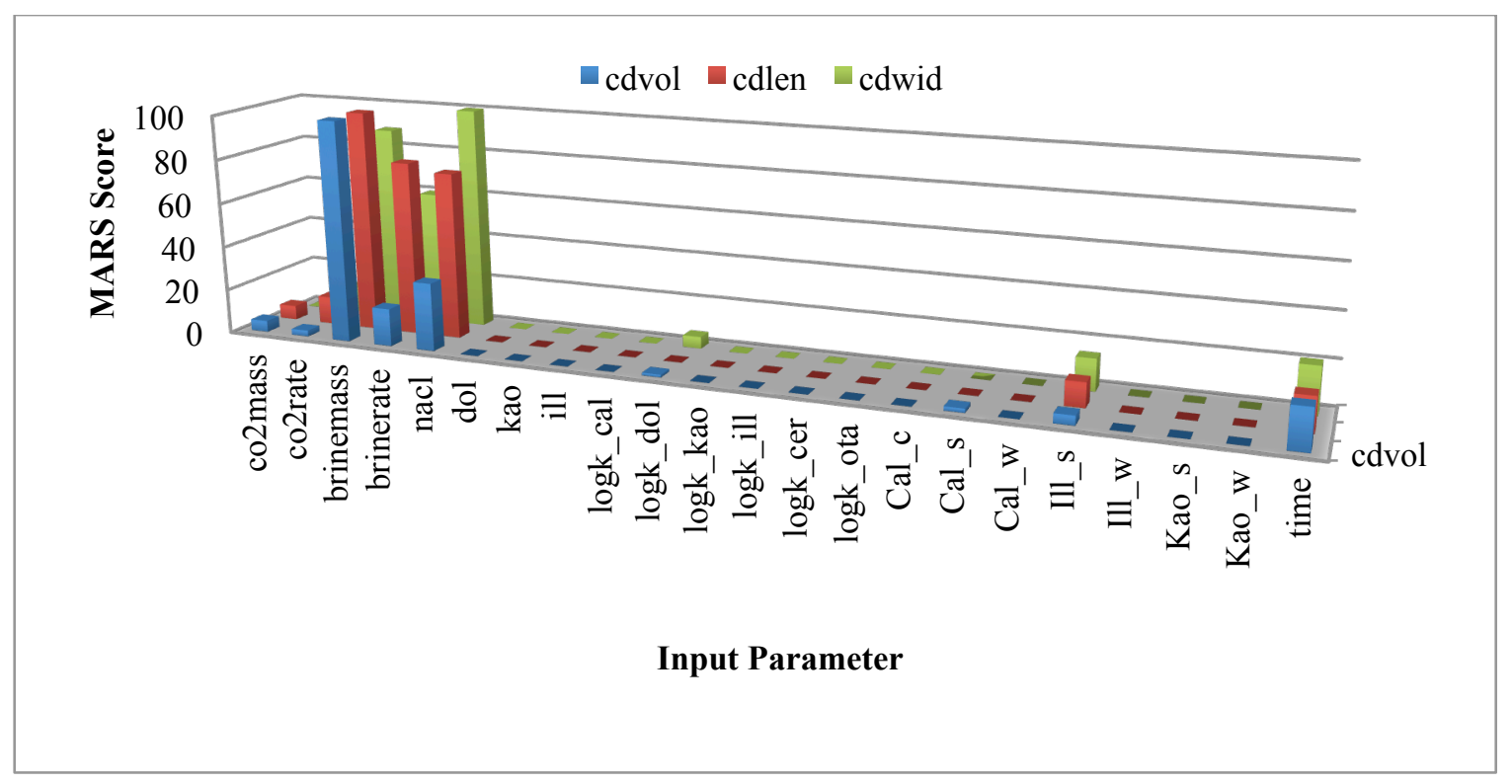

Figure 6.21. Input parameter ranking for Cd plume size using no-impact limits.

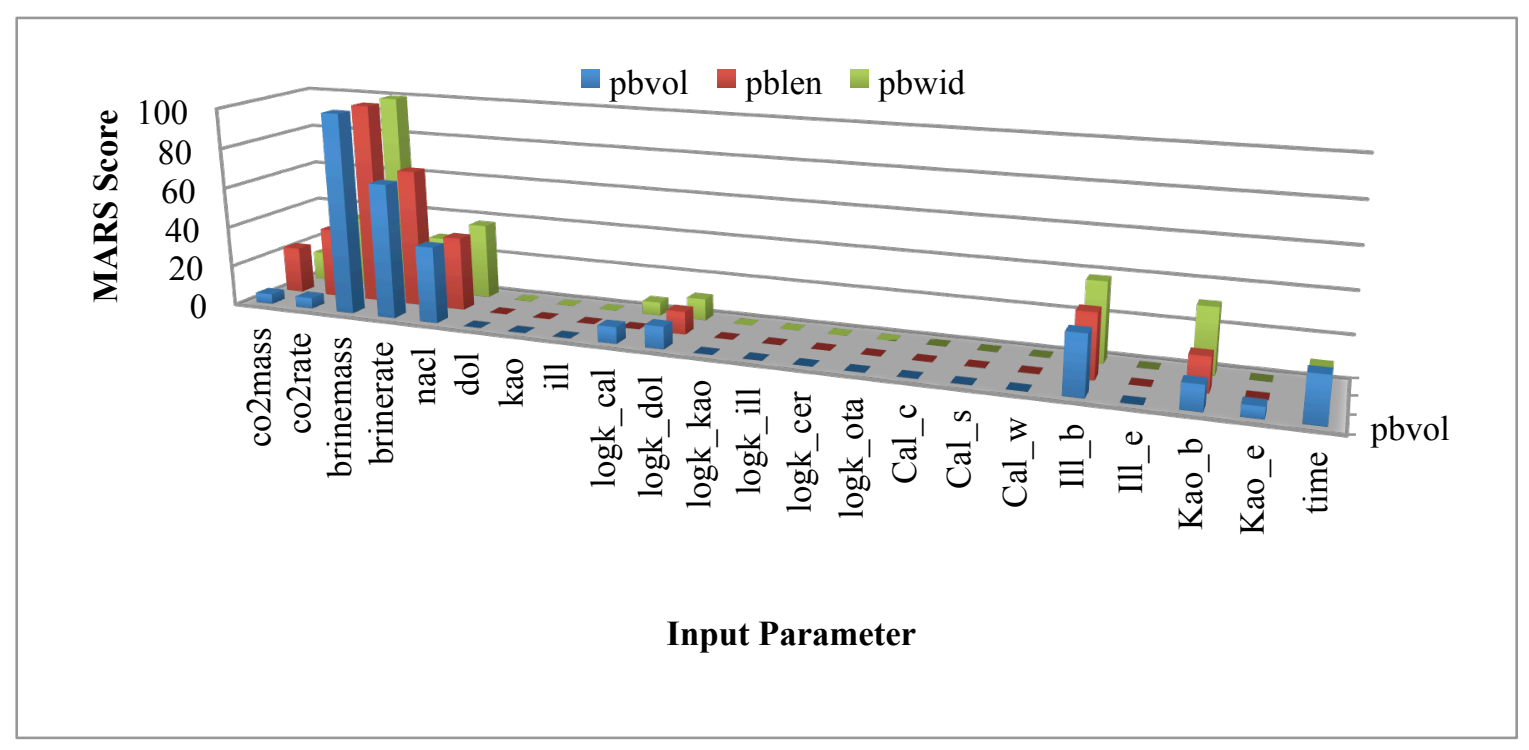

Figure 6.22. Input parameter ranking for $\mathrm{Pb}$ plume size using MCL limits. 


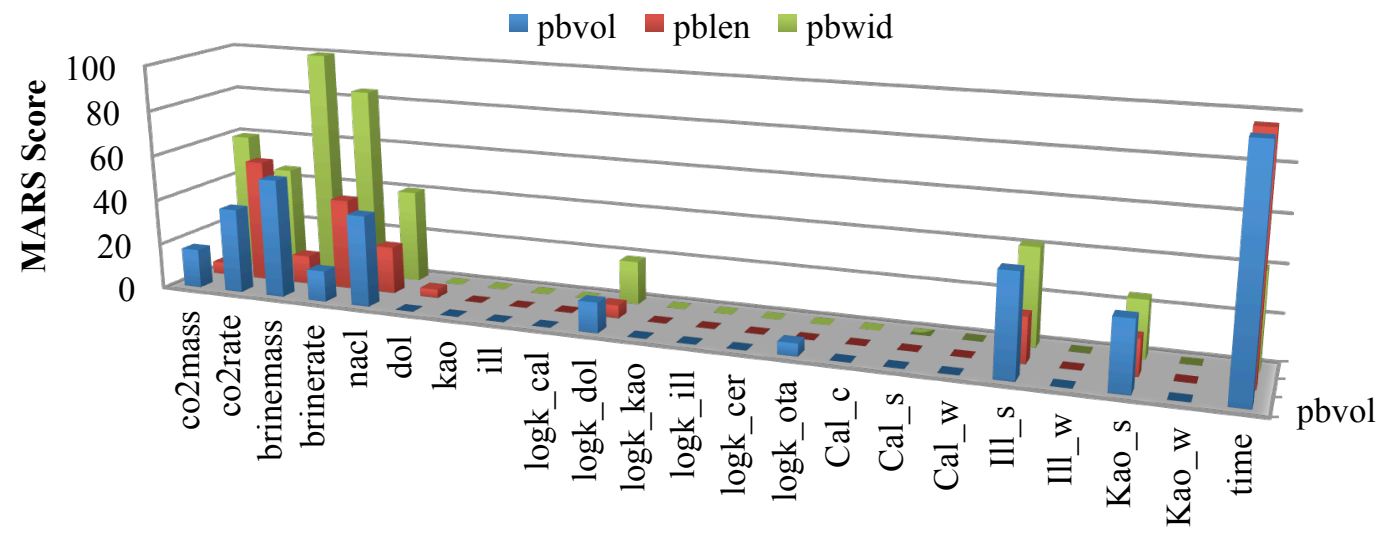

Input Parameter

Figure 6.23. Input parameter ranking for $\mathrm{Pb}$ plume size using no-impact limits.

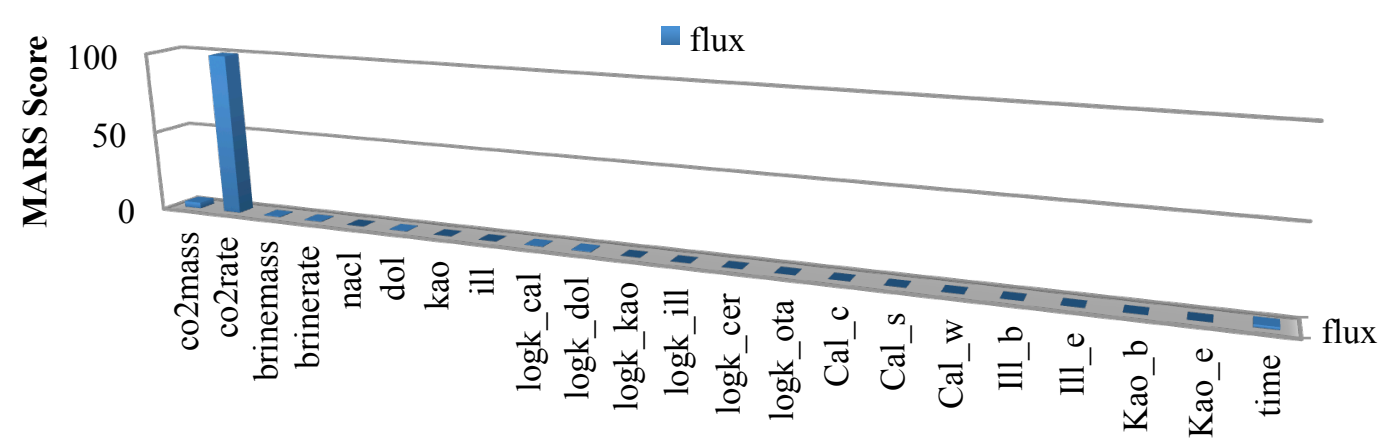

Input Parameter

Figure 6.24. Input parameter ranking for $\mathrm{CO}_{2}$ flux to atmosphere.

\subsection{Reduced-Order Model}

A ROM for wellbore leakage of $\mathrm{CO}_{2}$ into the Edwards Aquifer was developed using the results of the 1024 simulations and quadratic polynomial regression. Each of the 16 output variables listed in Table 6.2 was regressed against the 22 input parameters listed in Table 6.4 to determine the coefficients for the linear, cross, and square terms of the polynomial equations that minimized the sum of squared error between the observed and predicted output variables. The output variables are designated as $\mathrm{Y}_{1}$ to $\mathrm{Y}_{16}$, the input parameters are designated as $\mathrm{X}_{1}$ through $\mathrm{X}_{22}$, and the fitting coefficients as $a$ :

$$
\mathrm{Y}_{\mathrm{k}}=a_{\mathrm{i}, \mathrm{k}} \mathrm{X}_{\mathrm{i}}+a_{\mathrm{i}, \mathrm{j}, \mathrm{k}} \mathrm{X}_{\mathrm{i}} \mathrm{X}_{\mathrm{j}}+a_{\mathrm{i}, \mathrm{i}, \mathrm{k}} \mathrm{X}_{\mathrm{i}}^{2} \text {, where } \mathrm{i}=1,22 \text { and } \mathrm{j}=1,22 \text { and } \mathrm{k}=1,16
$$


The goodness of fit $\left(\mathrm{R}^{2}\right)$ for each output variable is shown in Table 6.5. The $\mathrm{CO}_{2}$ flux to the atmosphere (Figure 6.25) has the highest $\mathrm{R}^{2}$ of 1 , because it is linearly correlated with the $\mathrm{CO}_{2}$ leak rate. In general, the volumes of the TDS (Figure 6.26 and Figure 6.27), $\mathrm{pH}$ (Figure 6.28 and Figure 6.29), As (Figure 6.30 and Figure 6.31), $\mathrm{Cd}$ (Figure 6.32 and Figure 6.33) and $\mathrm{Pb}$ (Figure 6.34 and Figure 6.35) plumes have higher $\mathrm{R}^{2}$ values than the lengths and widths. The volumes of the plumes are strongly correlated with the $\mathrm{CO}_{2}$ and brine leak rates and cumulative mass leaked. The lengths and widths of the plumes are also correlated with these variables, but are also influenced by the permeability and porosity of the aquifer, which are spatially variable. The $\mathrm{R}^{2}$ for the $\mathrm{Cd}$ plume dimensions using the MCL limits is low because so few samples result in plumes that exceed the MCL limits, and the Cd plumes are very small, with very little variation in size.

Table 6.5. Regression goodness of fit $\left(\mathrm{R}^{2}\right)$ for each output variable.

\begin{tabular}{cllcc}
\hline Variable & \multicolumn{1}{c}{ Name } & Description & $\mathrm{R}^{2}($ No-Impact) & $\mathrm{R}^{2}(\mathrm{MCL})$ \\
\hline 1 & $\mathrm{CO}_{2}$ flux to atmosphere & flux & $1.00 \mathrm{E}+00$ & $1.00 \mathrm{E}+00$ \\
2 & Length of TDS plume & tdslen & $8.46 \mathrm{E}-01$ & $8.47 \mathrm{E}-01$ \\
3 & Volume of TDS plume & tdsvol & $9.28 \mathrm{E}-01$ & $9.30 \mathrm{E}-01$ \\
4 & Width of TDS plume & tdswid & $8.49 \mathrm{E}-01$ & $8.56 \mathrm{E}-01$ \\
5 & Length of pH plume & phlen & $8.35 \mathrm{E}-01$ & $8.34 \mathrm{E}-01$ \\
6 & Volume of pH plume & phvol & $9.33 \mathrm{E}-01$ & $9.34 \mathrm{E}-01$ \\
7 & Width of pH plume & phwid & $8.58 \mathrm{E}-01$ & $8.57 \mathrm{E}-01$ \\
8 & Length of arsenic plume & aslen & $8.74 \mathrm{E}-01$ & $9.67 \mathrm{E}-01$ \\
9 & Volume of arsenic plume & asvol & $9.79 \mathrm{E}-01$ & $9.48 \mathrm{E}-01$ \\
10 & Width of arsenic plume & aswid & $8.90 \mathrm{E}-01$ & $8.98 \mathrm{E}-01$ \\
11 & Length of cadmium plume & cdlen & $9.63 \mathrm{E}-01$ & $8.68 \mathrm{E}-01$ \\
12 & Volume of cadmium plume & cdvol & $9.85 \mathrm{E}-01$ & $8.68 \mathrm{E}-01$ \\
13 & Width of cadmium plume & cdwid & $9.61 \mathrm{E}-01$ & $7.88 \mathrm{E}-01$ \\
14 & Length of lead plume & pblen & $8.78 \mathrm{E}-01$ & $9.11 \mathrm{E}-01$ \\
15 & Volume of lead plume & pbvol & $9.53 \mathrm{E}-01$ & $9.74 \mathrm{E}-01$ \\
16 & Width of lead plume & pbwid & $8.90 \mathrm{E}-01$ & $9.29 \mathrm{E}-01$ \\
\hline
\end{tabular}

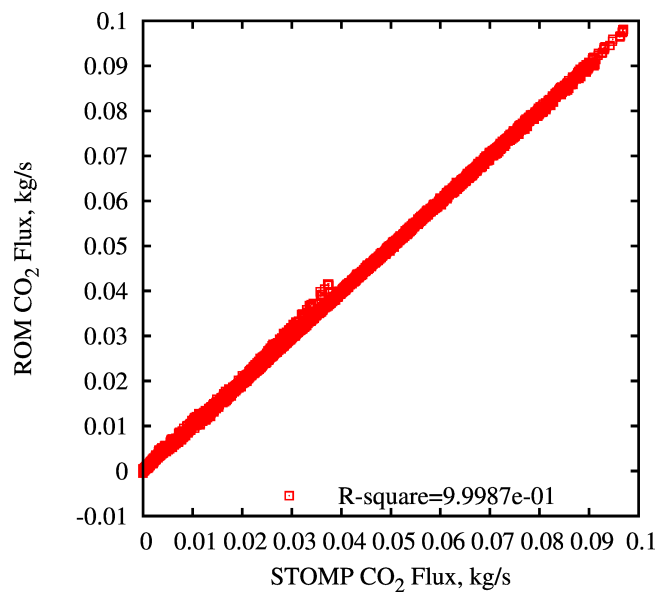

Figure 6.25. Comparison of $\mathrm{CO}_{2}$ flux to the atmosphere predicted by ROM and STOMP. 

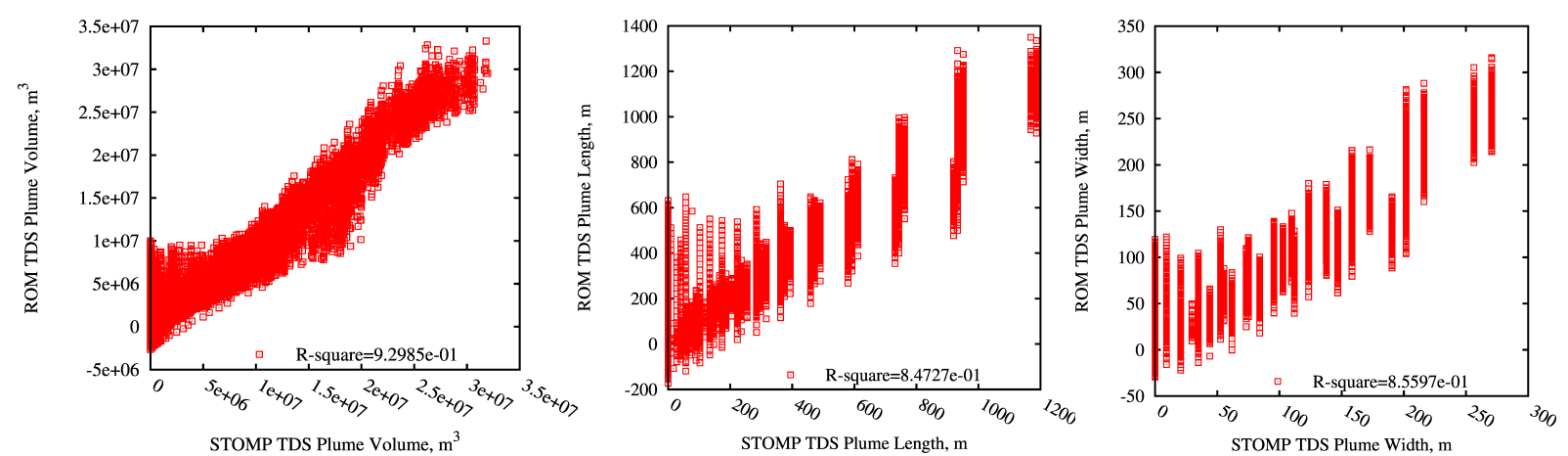

Figure 6.26. Comparison of TDS plume sizes predicted by ROM and STOMP using MCL limits.
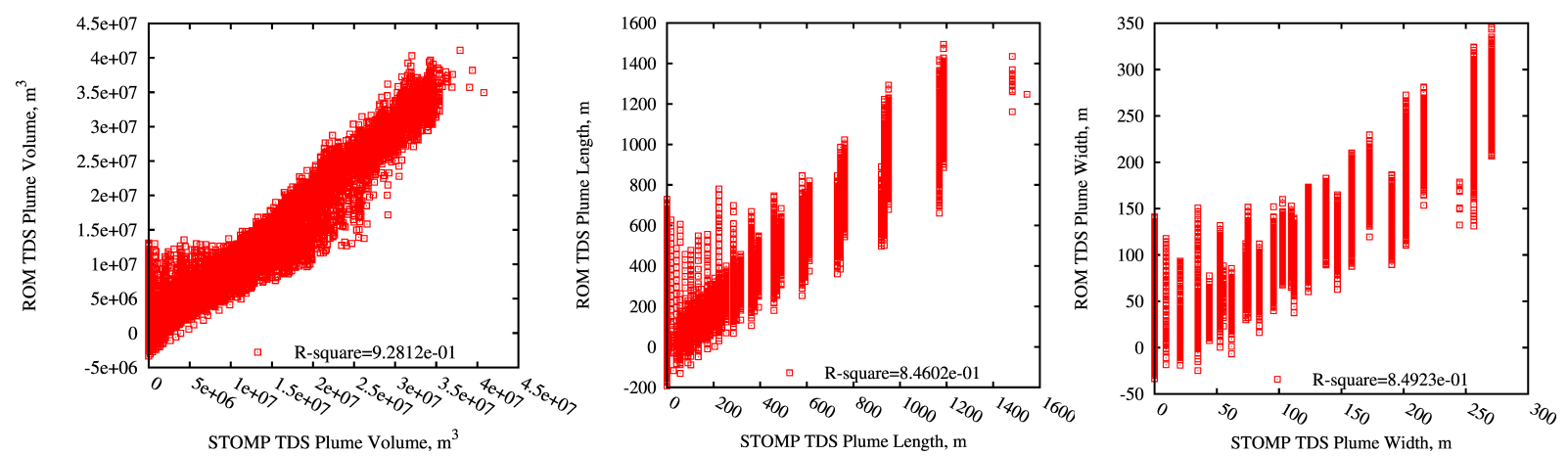

Figure 6.27. Comparison of TDS plume sizes predicted by ROM and STOMP using no-impact limits.
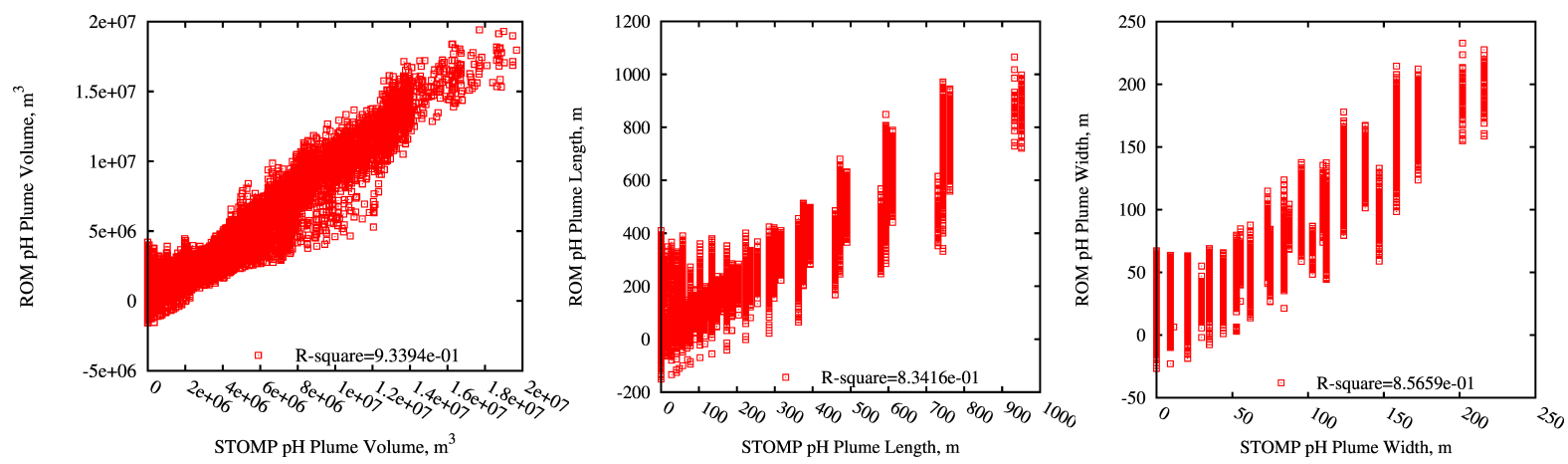

Figure 6.28. Comparison of $\mathrm{pH}$ plume sizes predicted by ROM and STOMP using MCL limits.
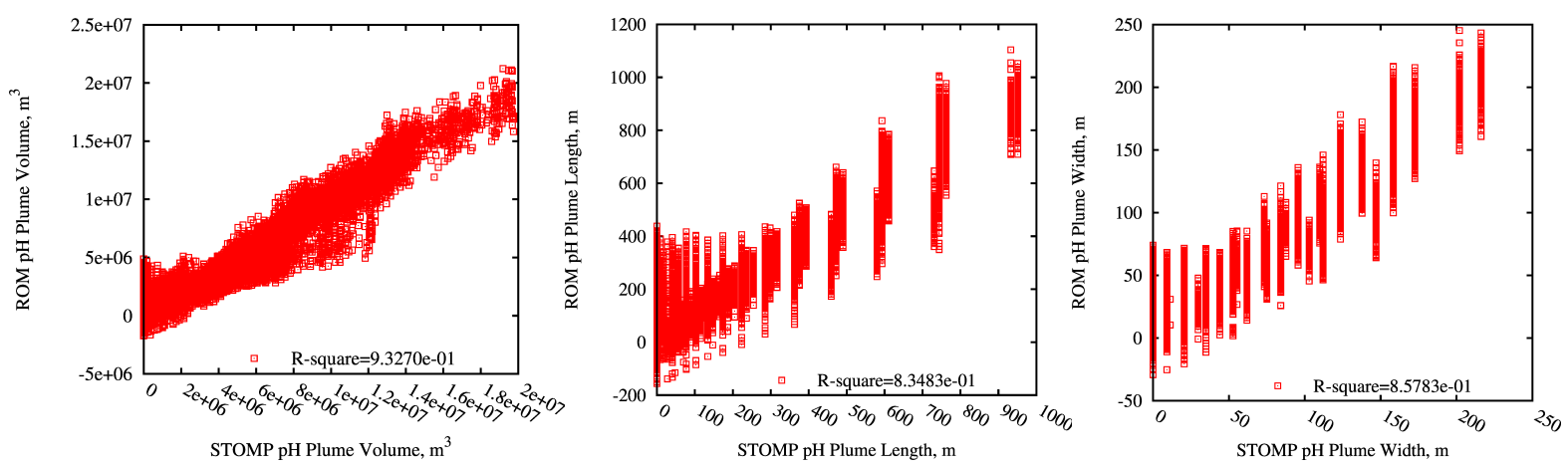

Figure 6.29. Comparison of $\mathrm{pH}$ plume sizes predicted by ROM and STOMP using no-impact limits. 

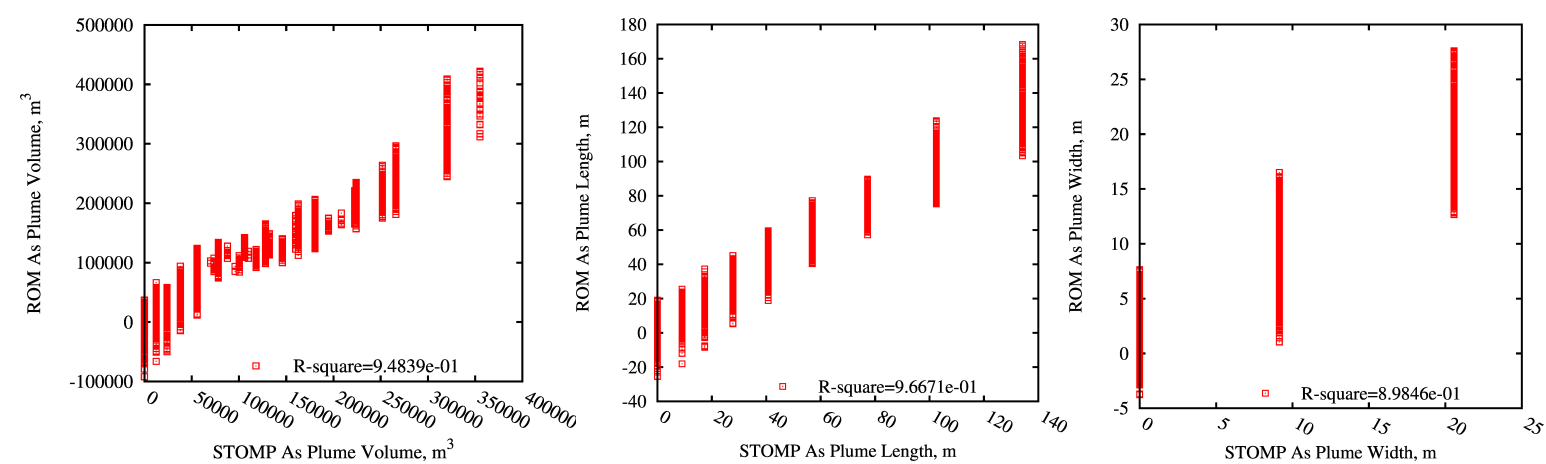

Figure 6.30. Comparison of As plume sizes predicted by ROM and STOMP using MCL limits.
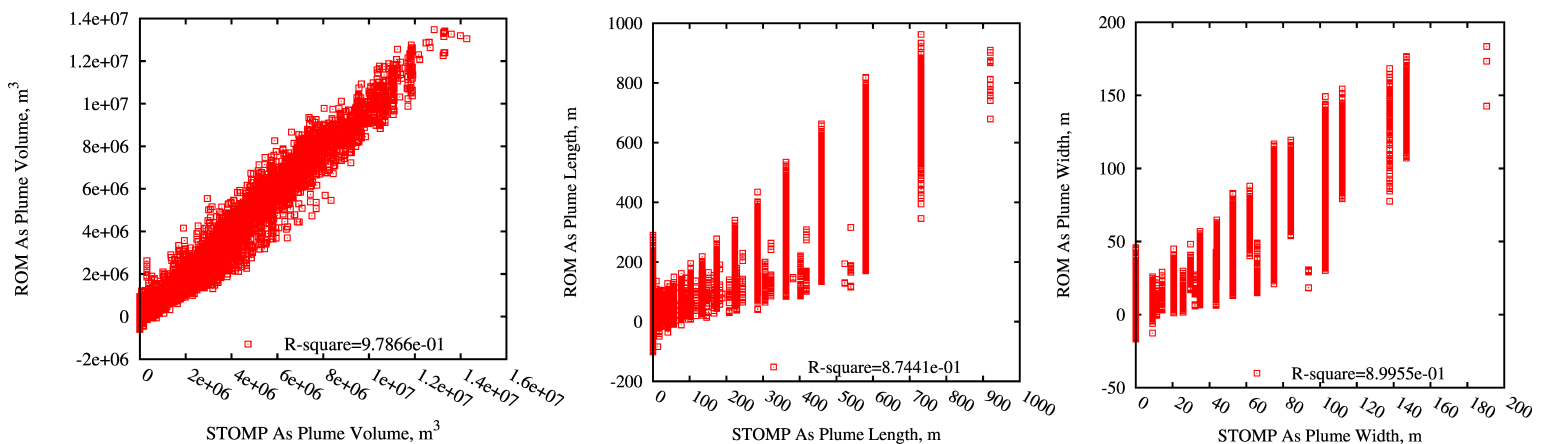

Figure 6.31. Comparison of As plume sizes predicted by ROM and STOMP using no-impact limits.
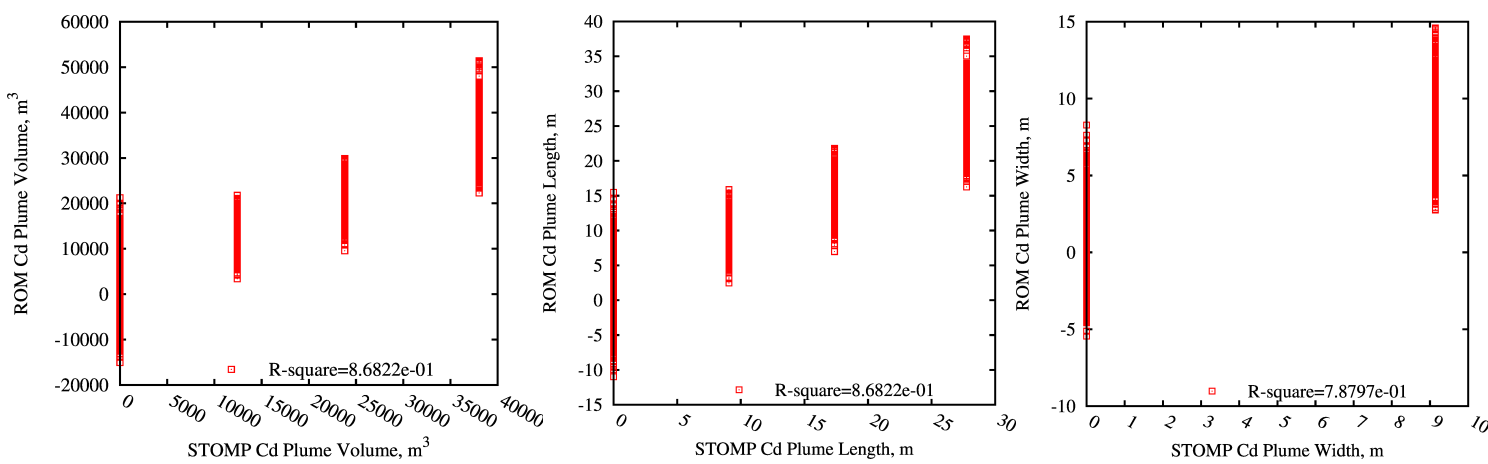

Figure 6.32. Comparison of Cd plume sizes predicted by ROM and STOMP using MCL limits.
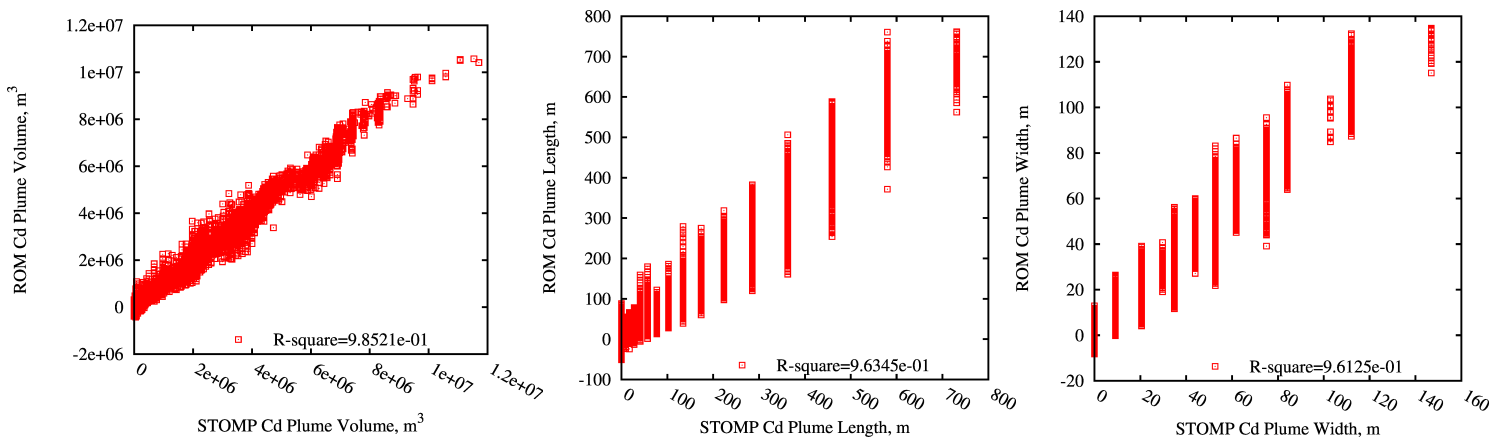

Figure 6.33. Comparison of $\mathrm{Cd}$ plume sizes predicted by ROM and STOMP using no-impact limits. 

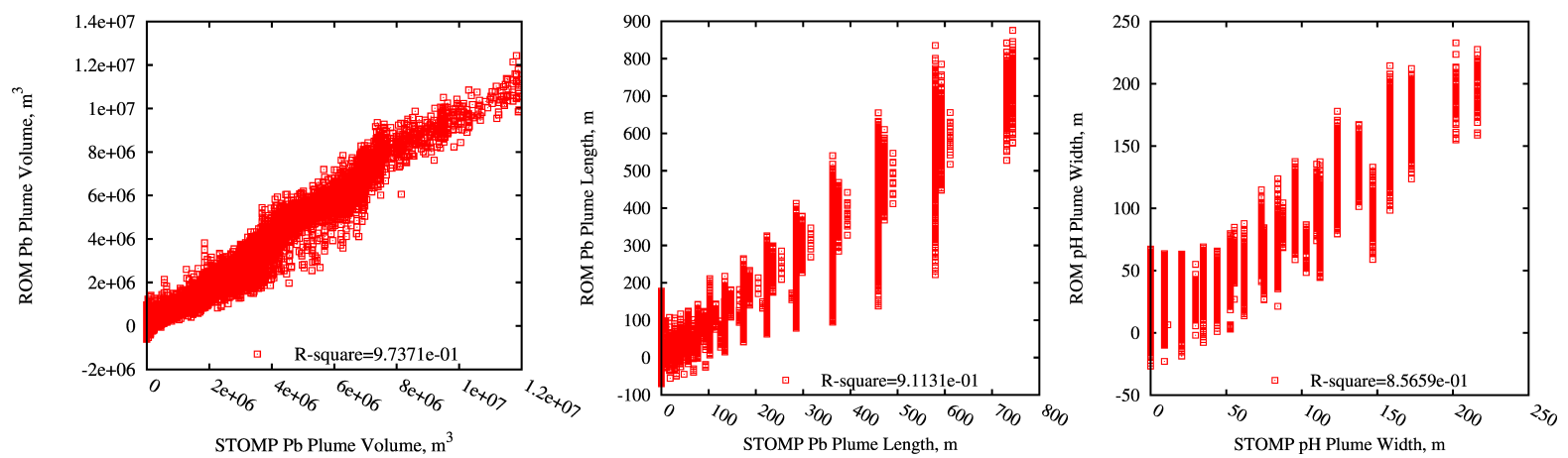

Figure 6.34. Comparison of $\mathrm{Pb}$ plume sizes predicted by ROM and STOMP using MCL limits.
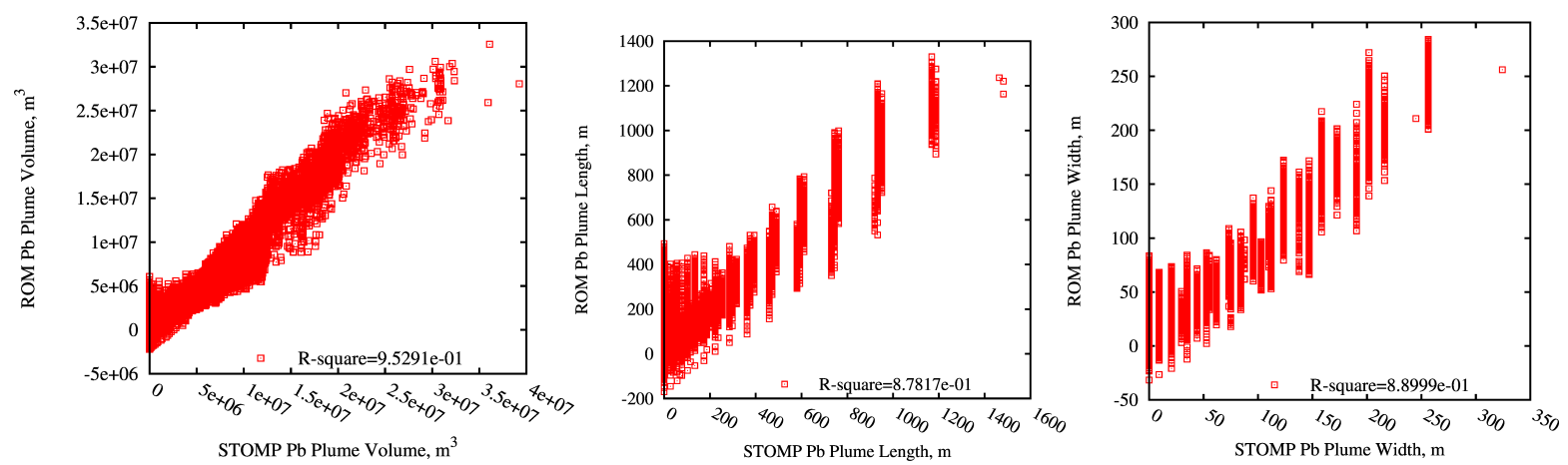

Figure 6.35. Comparison of $\mathrm{Pb}$ plume sizes predicted by ROM and STOMP using no-impact limits.

\subsection{Linking Function}

Ideally, the ROM described in this report would have been based on a three-dimensional reactive transport model. However, given that over a thousand runs were required to develop the ROM, and run times for a three-dimensional reactive transport model exceeded the run time limits on many supercomputers and clusters, a different approach was needed. Researchers at LANL focused on creating a ROM for the Edwards Aquifer to account for uncertainties related to flow and transport and for the impact of multiple wells, but a simpler geochemical reaction network than is described in Section 3.4. The simple geochemical reaction network consisted of kinetic calcite dissolution and precipitation (Table 3.2) and three equilibrium reactions (Table 6.6).

Table 6.6. Equilibrium aqueous reactions for simple geochemical model.

\begin{tabular}{lc}
\hline \multicolumn{1}{c}{ Equilibrium Reaction } & Equilibrium Coefficient at $25^{\circ} \mathrm{C}, \log$ \\
\hline $\mathrm{H}_{2} \mathrm{O}=\mathrm{OH}^{-}+\mathrm{H}^{+}$ & -14.001 \\
$\mathrm{HCO}_{3}{ }^{-}+\mathrm{H}^{+}=\mathrm{CO}_{2}+\mathrm{H}_{2} \mathrm{O}$ & 6.353 \\
$\mathrm{HCO}_{3}{ }^{-}=\mathrm{CO}_{3}{ }^{2-}+\mathrm{H}^{+}$ & -10.327 \\
\hline
\end{tabular}

A way to link the flow and transport ROM developed by LANL and the groundwater geochemistry ROM developed at PNNL is needed. To determine the relationship between the complex and simple geochemistry models for the Edwards Aquifer, all of the simulations described in Sections 6.1 and 6.2 
were rerun using the simple geochemical reaction network. The response variables for the simple and complex geochemistry simulations were plotted against one another and a linear slope was fit to the data. The relationships that emerge are not necessarily simple ones (Figure 6.36). The relationship for $\mathrm{pH}$ has a slope close to 1, but there is a great deal of scatter; the simple model either over- or under-predicts the results of the complex model by factors of two. The relationships for TDS and $\mathrm{CO}_{2}$ flux to the atmosphere also have slopes close to 1, and there is much less scatter, making these relationships less uncertain. The relationship for As plume volume has a slope of 1.377, indicating that the As plumes will be significantly larger for the complex geochemical model. In the complex model, As is adsorbed to calcite, kaolinite, and illite initially, in proportion to the initial As concentrations in groundwater samples. The leakage of $\mathrm{CO}_{2}$ and brine into the aquifer causes As to be released from the aquifer sediments, in addition to what may be leaked from the wellbore. The relationship for the $\mathrm{Cd}$ plume volume has a slope of 0.938 , indicating that the Cd plumes will be smaller for the complex geochemistry model. No Cd has been observed in the Edwards Aquifer, but in the complex geochemistry model, any Cd that leaks from the wellbore may be adsorbed to kaolinite and illite. The relationship for the $\mathrm{Pb}$ plume volume is close to 1 , and the scatter is moderate. Future work will focus on determining the relationship between the twodimensional model with complex geochemistry and the three-dimensional model with simple geochemistry.
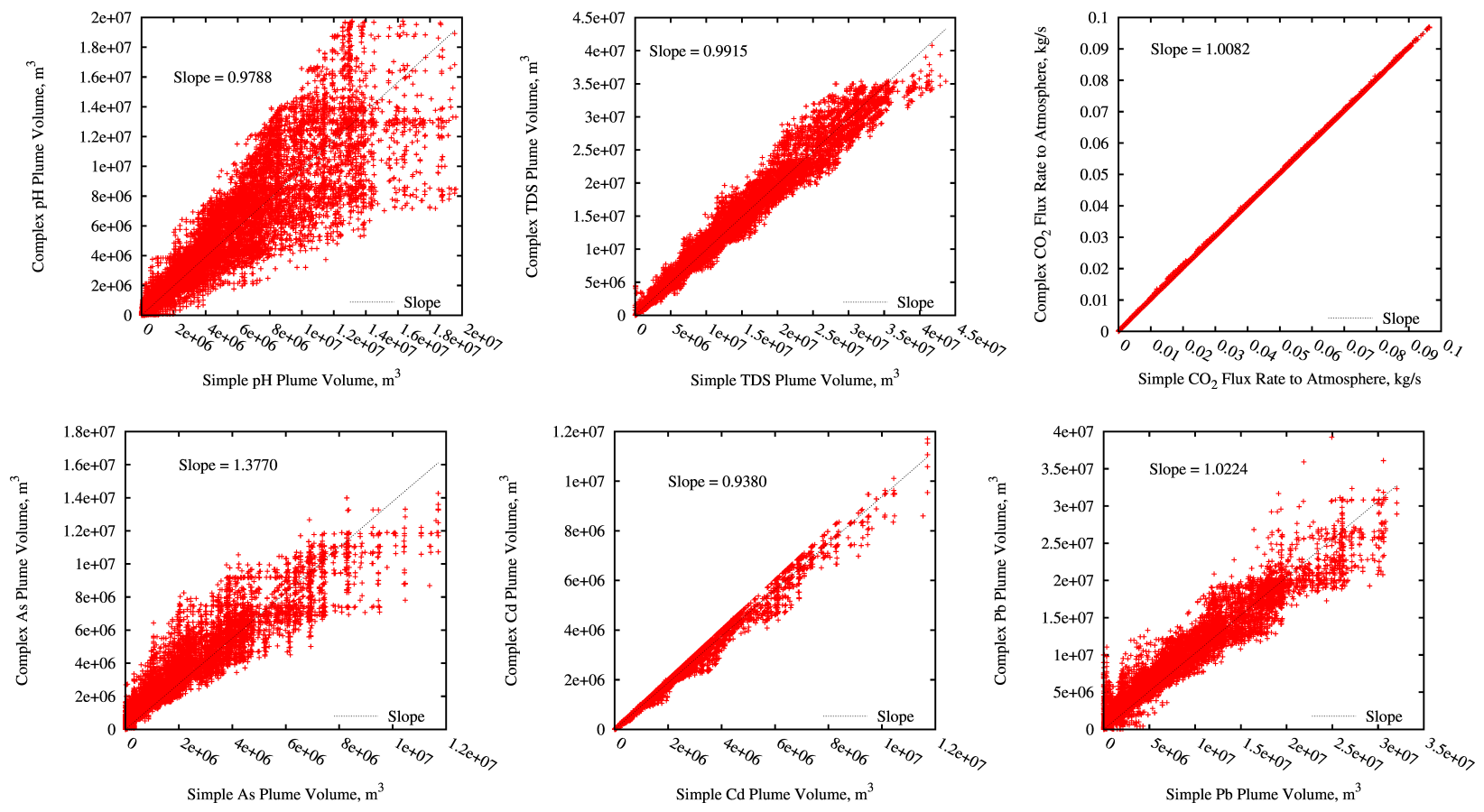

Figure 6.36. Comparison of response variables ( $\mathrm{pH}, \mathrm{TDS}, \mathrm{CO}_{2}$ fluxes to the atmosphere, $\mathrm{As}, \mathrm{Cd}$, and $\mathrm{Pb}$ ) predicted by simple and complex geochemical models using no-impact threshold limits. 



\subsection{References}

Back W. 1966. Hydrochemical facies and ground-water flow patterns in northern part of Atlantic Coastal Plain. Professional Paper 498-A, U.S. Geological Survey, Washington, D.C.

Bacon DH, JR Sminchak, JL Gerst, and N Gupta. 2009a. "Validation of CO2 Injection Simulations with Monitoring Well Data." Energy Procedia 1(1):1815-1822.

Bacon DH, MD White, N Gupta, JR Sminchak, and ME Kelley. 2009b. "CO2 Injection Potential in the Rose Run Formation at the Mountaineer Power Plant, New Haven, West Virginia." In AAPG Studies in Geology \# 59: Carbon Dioxide Sequestration in Geological Media - State of the Science, American Association of Petroleum Geologists, Tulsa, Oklahoma.

Barnes DA, DH Bacon, and SR Kelley. 2009. "Geological sequestration of carbon dioxide in the Cambrian Mount Simon Sandstone: Regional storage capacity, site characterization, and largescale injection feasibility, Michigan Basin.” Environmental Geosciences 16(3):163-183.

Bartos TT and KM Ogle. 2002. Water quality and environmental isotopic analyses of ground-water samples collected from the Wasatch and Fort Union Formations in areas of coalbed methane development : implications to recharge and ground-water flow, eastern Powder River basin, Wyoming. Water-Resources Investigations Report 2002-4045, U.S. Geological Survey, Washington, D.C.

Blanc P, A Lassin, P Piantone, M Azaroual, N Jacquemet, A Fabbri, and EC Gaucher. 2012. "Thermoddem: a geochemical database focused on low temperature water/rock interactions and waste materials." Applied Geochemistry 27(10):2107-2116.

Cardwell WT and RL Parsons. 1945. "Average Permeabilities of Heterogeneous Oil Sands." Transactions of the American Institute of Mining and Metallurgical Engineers 160:34-42.

Friedman JH. 1991. "Multivariate adaptive regression splines." Annals of Statistics 19(1):1-67.

Goldberg S. 2002. "Competitive adsorption of arsenate and arsenite on oxides and clay minerals." Soil Science Society of America Journal 66(2):413-421.

$\mathrm{Gu} \mathrm{X}$ and LJ Evans. 2007. "Modelling the adsorption of $\mathrm{Cd}(\mathrm{II}), \mathrm{Cu}(\mathrm{II}), \mathrm{Ni}$ (II), $\mathrm{Pb}$ (II), and $\mathrm{Zn}$ (II) onto Fithian illite." Journal of Colloid and Interface Science 307(2):317-325.

$\mathrm{Gu} \mathrm{X}$ and LJ Evans. 2008. "Surface complexation modelling of $\mathrm{Cd}(\mathrm{II}), \mathrm{Cu}(\mathrm{II}), \mathrm{Ni}(\mathrm{II}), \mathrm{Pb}(\mathrm{II})$ and $\mathrm{Zn}(\mathrm{II})$ adsorption onto kaolinite." Geochimica et Cosmichimica Acta 72(2):267-276.

Hutchison WR and ME Hill. 2011. Recalibration of the Edwards (Balcones Fault Zone) Aquifer Barton Springs Segment - Groundwater Flow Model. Texas Water Development Board, Austin, Texas.

Last GV, CJ Murray, CF Brown, PD Jordan, and M Sharma. 2013. No-Impact Threshold Values for NRAP's Reduced Order Models. PNNL-22077, Pacific Northwest National Laboratory, Richland, Washington.

Li D, B Beckner, and A Kumar. 2001. "A new efficient averaging technique for scaleup of multimillioncell geologic models." SPE Reservoir Evaluation \& Engineering 4(4):297-307.

Lynch F, B Mahler, and N Hauwert. 2007. "Provenance Of Suspended Sediment Discharged From A Karst Aquifer Determined By Clay Mineralogy." In Studies of Cave Sediments, ID Sasowsky and J Mylroie, 83-93, Springer Netherlands. 
Musgrove M, L Fahlquist, NA Houston, RJ Lindgren, and PB Ging. 2010. Geochemical evolution processes and water-quality observations based on results of the National Water-Quality Assessment Program in the San Antonio segment of the Edwards aquifer, 1996-2006. Scientific Investigations Report 2010-5129, U.S. Geological Survey, Washington, D.C.

Parkhurst DL and CAJ Appelo. 1999. User's guide to PHREEQC (Version 2) : a computer program for speciation, batch-reaction, one-dimensional transport, and inverse geochemical calculations. Water Resources Investigations Report 99-4259, U.S. Geological Survey, Washington, D.C.

Pittman JS. 1959. "Silica in Edwards Limestone, Travis County, Texas." In Silica in Sediments, SEPM Society for Sedimentary Geology, Tulsa, Oklahoma.

Pruess K, J García, T Kovscek, C Oldenburg, J Rutqvist, C Steefel, and T Xu. 2004. “Code intercomparison builds confidence in numerical simulation models for geologic disposal of $\mathrm{CO} 2 . "$ Energy 29(9-10):1431-1444.

Sø HU, D Postma, R Jakobsen, and F Larsen. 2008. "Sorption and desorption of arsenate and arsenite on calcite." Geochimica et Cosmochimica Acta 72(24):5871-5884.

Sø HU, D Postma, R Jakobsen, and F Larsen. 2011. "Sorption of phosphate onto calcite; results from batch experiments and surface complexation modeling." Geochimica et Cosmochimica Acta 75(10):2911-2923.

White MD and BP McGrail. 2005. STOMP, Subsurface Transport Over Multiple Phases, Version 1.0, Addendum: ECKEChem, Equilibrium-Conservation-Kinetic Equation Chemistry and Reactive Transport. Pacific Northwest National Laboratory, Richland, Washington.

White MD and M Oostrom. 2006. STOMP: Subsurface Transport Over Multiple Phases, Version 4.0, User's Guide. Pacific Northwest National Laboratory, Richland, Washington.

White MD, M Oostrom, and RJ Lenhard. 2004. "A practical model for mobile, residual, and entrapped NAPL in water-wet porous media." Groundwater 42(5):734-746. 



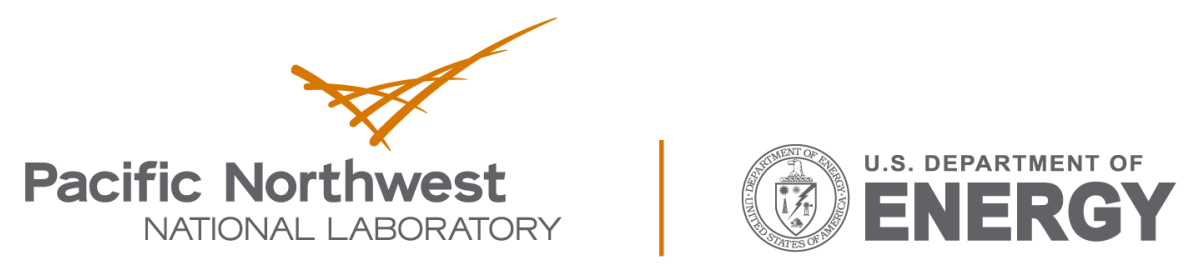

Proudly Operated by Battelle Since 1965

902 Battelle Boulevard

P.O. Box 999

Richland, WA 99352

1-888-375-PNNL (7665)

www.pnnl.gov 